\title{
Dominica: 2010 Article IV Consultation-Staff Report; Staff Supplement and Public Information Notice on the Executive Board Discussion
}

Under Article IV of the IMF's Articles of Agreement, the IMF holds bilateral discussions with members, usually every year. In the context of the 2010 Article IV consultation with Dominica, the following documents have been released and are included in this package:

- $\quad$ The staff report for the 2010 Article IV consultation, prepared by a staff team of the IMF, following discussions that ended on January 28, 2010, with the officials of Dominica on economic developments and policies. Based on information available at the time of these discussions, the staff report was completed on April 27, 2010. The views expressed in the staff report are those of the staff team and do not necessarily reflect the views of the Executive Board of the IMF.

- A staff supplement on the joint IMF/World Bank debt sustainability analysis.

- $\quad$ A Public Information Notice (PIN) summarizing the views of the Executive Board as expressed during its May 10, 2010 discussion of the staff report that concluded the Article IV consultation.

The policy of publication of staff reports and other documents allows for the deletion of market-sensitive information.

\author{
Copies of this report are available to the public from \\ International Monetary Fund • Publication Services \\ $70019^{\text {th }}$ Street, N.W. • Washington, D.C. 20431 \\ Telephone: (202) 623-7430 • Telefax: (202) 623-7201 \\ E-mail: publications@imf.org Internet: http://www.imf.org
}

\section{International Monetary Fund Washington, D.C.}




\section{INTERNATIONAL MONETARY FUND}

\section{DOMINICA}

\section{Staff Report for the 2010 Article IV Consultation}

Prepared by the Staff Representatives for the 2010 Consultation with Dominica

Approved by Antônio Furtado (WHD) and Michele Shannon (SPR)

April 27, 2010

- Discussions. Article IV consultation discussions were held in Roseau during January 18-28, 2010. The mission comprised Messrs. Monroe (head), Gonzalez-Garcia, Lemus and Tashu (all WHD), and ECCB and CDB staff also participated. Mr. McGoldrick (OED) joined the concluding meeting. The mission met with Prime Minister Skerrit, the Cabinet, the Financial Secretary, and other senior government officials, as well as representatives of the private sector.

- Background. The global downturn has adversely affected the Dominican economy through lower stayover tourist arrivals, FDI inflows, and remittances from Dominicans abroad, but not as severely as other Eastern Caribbean economies. Dominica has benefited from a relatively favorable fiscal position, which allowed the government to respond to the global slowdown by maintaining capital spending at the high post-hurricane level in 2008.

- Focus of the consultation. The discussions centered on policies to ensure fiscal sustainability, reduce financial sector vulnerability, and enhance the medium-term outlook for growth.

- Key policy recommendations. The fiscal stance for FY2009/10 continues to be based on an appropriate target of 3 percent of GDP for the primary surplus. However, in the next three years, additional spending to be financed by external loans would imply a substantial weakening of the primary surplus. To ensure debt sustainability, a primary surplus of 3 percent of GDP should be restored as soon as possible. In the financial sector, the collapse of the Trinidad and Tobagobased CL Financial Group and the large role played by credit unions underscore the need to strengthen the supervision of non-bank financial institutions. Resolution of the CL Financial subsidiary British American Insurance Company (BAICO) should proceed promptly and the financial difficulties of a second subsidiary, the Colonial Life Insurance Company (CLICO), will also require close monitoring. In addition, the authorities should continue to make progress with structural reforms geared toward improving the business environment.

- Fund relations. In July 2009, the Executive Board approved a disbursement of SDR 3.28 million (about US\$5.1 million) under the Rapid-Access Component of the Exogenous Shocks Facility (RAC-ESF). Dominica has accepted the obligations of Article VIII, Sections 2, 3 and 4, and maintains an exchange system free of restrictions on the making of payments and transfers for current international transactions. The last Article IV consultation was concluded in July 2008. 
Contents

Page

Executive Summary. 3

I. Economic and Political Context 4

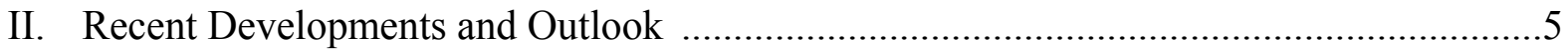

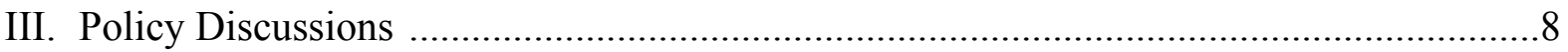

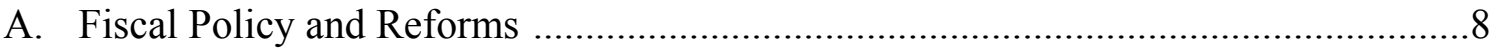

B. Financial Sector Policies ............................................................................. 11

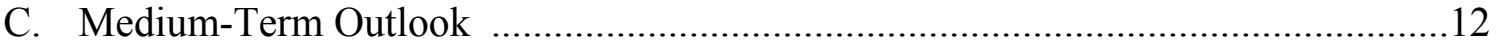

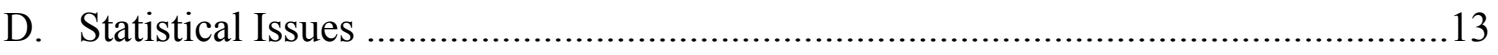

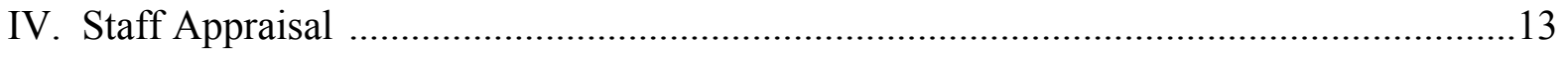

Appendices

I. Impact of the Global Crisis on the Eastern Caribbean Currency Union ........................15

II. Exchange Rate and Competitiveness Assessment ...................................................16

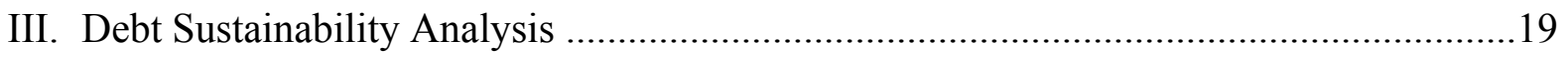

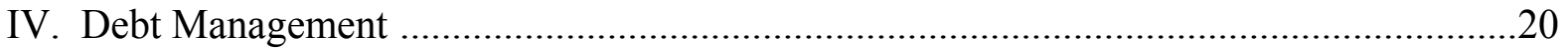

Tables

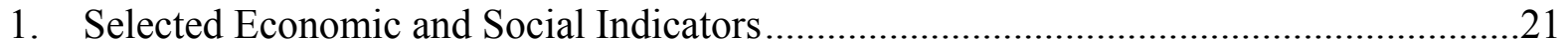

2. Summary Accounts of the Central Government........................................................22

3. Summary Accounts of the Central Government........................................................23

4. Balance of Payments................................................................................................24

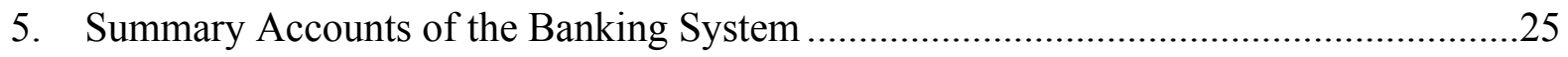

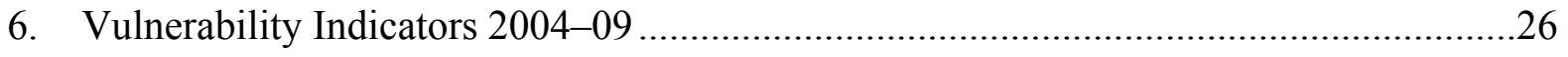

7. Medium-Term Macroeconomic Framework .......................................................2

Figures

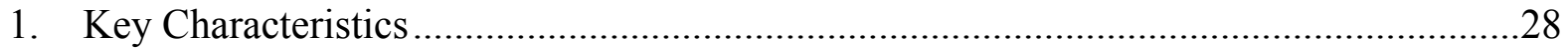

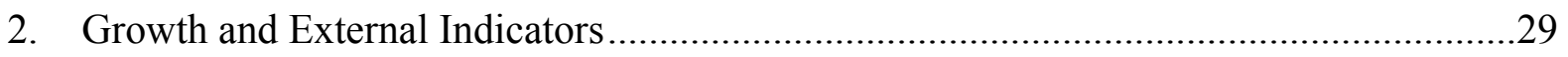

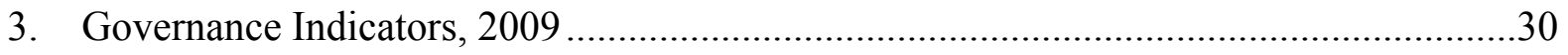

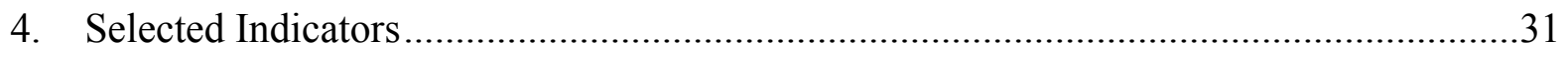

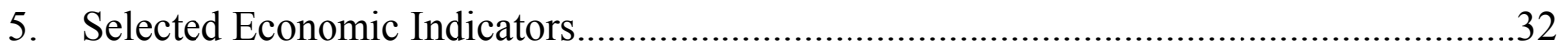

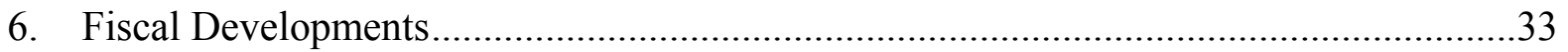

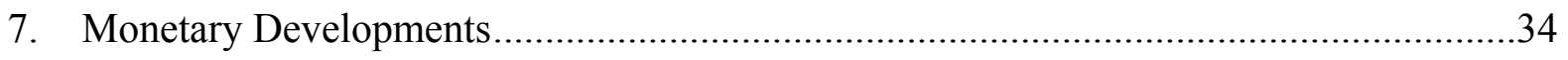

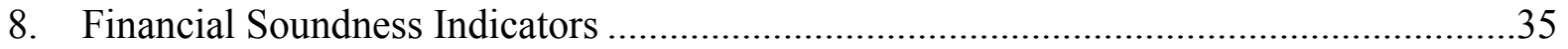




\section{EXECUTIVE SUMMARY}

Dominica, like other ECCU members, depends on tourism, foreign investment and remittances, and has high debt, openness, and disaster risks. However, in many ways, Dominica is an outlier, with a stronger macroeconomic framework, a less developed tourism sector, and a larger share of agriculture in GDP. As a result, the impact of the global downturn has been less severe than in other Eastern Caribbean countries, and economic activity in 2009 contracted only slightly.

In recent years, Dominica has maintained a prudent fiscal stance, anchored on a primary surplus of 3 percent of GDP. The debt-to-GDP ratio fell from 130 percent in 2003 to 84 percent in 2009, which has increased the government's flexibility to respond to shocks, in particular, by maintaining capital spending in 2009 at the high post-hurricane level in 2008. The latter was facilitated by the strong performance of the VAT, which, despite elevated spending levels, allowed the government to maintain a primary surplus of 3 percent of GDP in FY2008/09-FY2009/10.

However, additional spending to be financed by external loans would imply a substantial weakening of the primary surplus in the next three years. The government agreed with the Export-Import Bank of China on a concessional loan amounting to 11 percent of GDP for projects in education and infrastructure, about 7 percent of GDP of which would be for new spending. This will result in less favorable debt dynamics and potential credibility costs. Staff encourages the authorities to maintain a primary surplus of at least 1 percent of GDP and urges them to return to the fiscal anchor (a primary surplus of 3 percent of GDP) as soon as possible. The government was considering an additional loan of US\$60 million (16 percent of GDP) for a tourism resort. This additional borrowing would likely prevent Dominica from reaching the ECCB debt-to-GDP ratio target of 60 percent by the target date of 2020. Staff noted that it would be of paramount importance to carefully evaluate the project's viability and involve a private strategic partner, which authorities are actively pursuing.

Strengthening the supervision of the financial sector should be a priority. The collapse of the CL Financial Group and the large role played by credit unions underscore the need to strengthen the Financial Services Unit. ECCU members are making progress toward creating a new company to take over BAICO's operations in the region but finding sufficient funds to capitalize the new company will be a challenge. In addition, the financial difficulties of CLICO will require close monitoring. The mission emphasized the need for close monitoring of the Agricultural and Industrial Development Bank due to potential contingent fiscal liabilities and recommended an on-site examination.

Progress with structural reforms has been substantial. Dominica will benefit from automation of customs and land titling, the appointment of a second judge to hear civil matters, and the improvement of airport facilities. The medium-term growth challenge is to manage the transition from bananas to tourism and diversified agro industries, and to foster private sector-led growth and poverty reduction. 


\section{Economic and Political Context}

1. Dominica is a highly vulnerable, small island economy. It shares many characteristics with other Eastern Caribbean Currency Union (ECCU) members (Figures 1-4): it depends on tourism, foreign investment, and remittances; has a high debt level; has large current account deficits; and is vulnerable to external shocks due to its high degree of openness and elevated risk of natural disasters. Like other small island states, it has a relatively large government. Commodity exports have shown a secular downward trend for some decades, and the erosion of EU trade preferences has reduced implicit transfers from 5 percent of GDP in 1996-2001 to 11/2 percent in 2001-05.

2. However, in many ways, Dominica is an outlier within the ECCU. Growth has historically been lower than in other ECCU economies, particularly during 2001-05. The underperformance reflects its less-developed tourism sector and greater reliance on agriculture. These characteristics contributed to a relatively stronger performance during the global downturn. ${ }^{1}$ Dominica's emigration rate is particularly high-more than 30 percent of the labor force has emigrated - and its population is in fact falling. In 2003, around one third of the population -was below the poverty line, and inequality -was high. ${ }^{2}$ Dominica receives a high level of external grants, and, within the ECCU, had the lowest per capita GDP in 2008 of US\$4,931. Dominica has had a relatively high number of natural disasters even compared with other ECCU countries; most recently, Hurricanes Dean and Omar in 2007-08 together caused damages of 35 percent of GDP.

\section{Dominica has a relatively stronger fiscal position than other ECCU members,} and has made greater progress with debt reduction. It put its fiscal house in order after the 2001-02 crisis, with Fund support, and established a fiscal anchor of a 3 percent of GDP primary surplus, which has often been exceeded. ${ }^{3}$ The public debt-to-GDP ratio has fallen sharply. As a result, Dominica has been well positioned to undertake rehabilitation and reconstruction spending in the wake of natural disasters and to respond to external shocks.

\footnotetext{
${ }^{1}$ In 2008, agriculture accounted for 16 percent of GDP, compared to an average of 5 percent of GDP in the rest of the ECCU. By contrast, tourism accounted for only 8 percent of GDP, compared to an average of 13 percent of GDP in the rest of the ECCU.

${ }^{2}$ See the 2003 Country Poverty Assessment.

${ }^{3}$ These reforms were supported by a Stand-by Arrangement in 2002-03 and a Poverty Reduction and Growth Facility (PRGF) arrangement in 2003-06. In addition, in 2008, the Executive Board approved SDR 2.05 million (25 percent of quota) in emergency assistance to help the government deal with the effects of Hurricane Dean, and, as noted above, in 2009 the Board approved a RAC-ESF disbursement.
} 
4. The main drivers of inflation in Dominica, as in the rest of the ECCU, have been international fuel and food prices. Annual average inflation in Dominica during 2001-07 was only 1.9 percent. However, owing to international fuel and food price hikes, average inflation reached 6.4 percent in 2008 .

5. Dominica's Growth and Social Protection Strategy (GSPS) guides medium-term economic policies. The main goal of the GSPS is to foster economic growth and reduce poverty while reducing public debt. These objectives are to be pursued by maintaining prudent fiscal policies, strengthening the oversight of the financial sector, undertaking structural reforms to activate the economy, and improving the targeting of social assistance.

6. The authorities have implemented, to a large degree, the recommendations from the 2008 Article IV Consultation. Specifically: (i) in the fiscal area, a primary surplus of 3 percent of GDP was achieved in FY2008/09; (ii) regarding regulation and supervision of the financial sector, the authorities have continued to build the capacity of the Financial Services Unit (although the collapse of the CL Financial Group underscores the need for further progress); (iii) to improve disaster preparedness, they have continued to participate in the Caribbean Catastrophe Risk Insurance Facility (CCRIF); and (iv) to improve the business climate, structural reforms are being implemented including the automation of customs and land titling, plans to expand airport facilities, and the appointment of a second judge to hear civil matters. The authorities are continuing their efforts to enhance the diversification of the economy in particular by promoting the tourism sector.

7. National elections were held in December 2009 and Dominica scores well on a number of governance indicators. The increase in the Dominica Labor Party's majority suggests a strong mandate to continue with the government's economic and political agenda. Dominica has strong ratings for voice and accountability, political stability, government effectiveness, control of corruption, regulatory quality, and the rule of law.

\section{RECENT DEVELOPMENTS AND OUTLOOK}

8. The global downturn has adversely affected the Dominican economy through lower tourism arrivals, FDI inflows and remittances, albeit less severely than other ECCU economies (Appendix I). Real GDP is estimated to have declined by only 0.3 percent in 2009. Total tourism receipts contracted by 16 percent during 2009. This decline reflected falling stayover arrivals after the Reunion 2008 event and greater discounting by hotels in 2009. The decline was partly offset by extraordinary growth in cruise arrivals. FDI and remittances inflows dropped in 2009 by 51 percent and 18 percent, respectively. 
9. In response to the global slowdown, the government decided to maintain capital spending in 2009 at the high post-hurricane level in 2008. Despite high capital spending, the overall fiscal position remained in surplus during FY 2008/09 (July-June) and so far in FY 2009/10. This reflects primarily continuing strong performance of the VAT introduced in 2006. ${ }^{4}$ The strength in tax receipts also helped finance a scaling up of social assistance to protect the poor from the effects of the 2008 spike in food and fuel prices, as well as from the impact of the global economic downturn.

10. Consumer price inflation has picked up. The CPI increased by 4.4 percent (yoy) through February 2010, as continuing increases in world food and fuel prices were passed through. On a period average basis, inflation was close to zero.

11. The external current account deficit decreased to 28 percent of GDP in 2009. In 2008, the deficit had widened to 32 percent of GDP due to higher reconstruction-related and fuel imports. Lower FDI-related and fuel imports in 2009 are estimated to have more than offset lower tourism receipts and remittances.

12. Monetary aggregates show steady growth and the banking system has remained resilient. In the 12 months to December 2009, banking sector credit to the private sector grew by 6.9 percent and broad money by 10 percent. Prudential indicators suggest that banks are liquid and well capitalized. Nonperforming loans have declined, although banks have restructured loans in some cases. The average nonperforming loans ratio and capital-based soundness indicators remain above prudential norms, although returns on assets have declined markedly in recent years.

\footnotetext{
${ }^{4}$ VAT collections were 10 percent, 11 percent and 12 percent of GDP in FY 2006/07, FY 2007/08 and FY 2008/09, respectively. Dominica's VAT productivity ratio relative to GDP is superior to most small island economies, according to the Fiscal Affairs Department.
} 
13. The collapse of the Trinidad and Tobago-based CL Financial Group has exposed regional weaknesses in the regulation of nonbanks. In Dominica, the total exposure of residents to two insurance subsidiaries of the Group offering deposit-like annuity products amounts to about EC\$194 million (19.4 percent of GDP). The eight KPMG judicial managers appointed in each ECCU jurisdiction for the British American Insurance Company (BAICO) issued a joint report in October 2009 finding that the company is insolvent and illiquid. The ECCU member authorities are making progress in the creation of a new company to take over BAICO's operations in the region. Another subsidiary with operations in the ECCU, the Colonial Life Insurance Company of Barbados (CLICO), has been facing liquidity problems, and has been barred from writing new insurance business in Barbados.

14. There is no clear evidence of fundamental misalignment of the exchange rate. The CPI-based real effective exchange rate has been on a declining trend since 2002 and is an estimated 2 percent below equilibrium when assessed using the fundamentals-based approach (Appendix II). Other assessments give mixed results. An approach based on the Purchasing Power Parity (PPP) hypothesis suggests that the real exchange rate at end 2008 was undervalued by 9 percent. However, the macroeconomic balance approach indicates an overvaluation of 7 percent as the medium-term current account is 2.6 points of GDP above the current account norm. The conflicting indicators may reflect structural changes, including the improved macroeconomic environment after the 2001-02 crisis, and the prevalence of external shocks. Dominica has increased its share of ECCU and Caribbean stayover arrivals in recent years, which suggests that competitiveness may in fact be improving.

15. Dominica has achieved some success in improving social conditions. It has already reached or made significant progress toward several of the Millennium Development Goals, by raising primary enrollment to 99 percent, eliminating gender disparities in education, and reducing child mortality from 23 per 1000 in 1990 to 13 per 1000 in 2006 . However, poverty is high by Caribbean standards, with 40 percent of households in poverty and 10 percent of households very poor, according to the 2003 Country Poverty Assessment.

16. The near to medium-term economic outlook is modestly positive. With the recovery of the global economy and expected improvements in international trade and tourism activities, the Dominican economy is expected to grow by $1 \frac{1}{2}$ percent in 2010 . The downside risks are related to a potentially very slow recovery in advanced economies, which 
would adversely affect tourism activity. In addition, a rebalancing of global demand could imply weaker demand for tourism services from Dominica's main source markets.

\section{Policy Discussions}

\section{A. Fiscal Policy and Reforms}

17. Dominica has generally maintained a prudent fiscal stance, anchored on a 3 percent of GDP target for the primary surplus that allows for a steady decline in the public debt-to-GDP ratio. The introduction of a VAT in 2006 has contributed to a sustained increase in tax revenue, while the authorities have also been successful in containing current expenditure. The public debt has declined significantly, supported by the 2004-05 debt restructuring, ${ }^{5}$ a major reduction in the fiscal deficit, and the emphasis put on grants and concessional loans to finance capital expenditure. Notwithstanding these efforts, public debt remains high.

18. The authorities believe that the benchmark primary surplus of 3 percent of GDP is achievable in FY2009/10, far better than expected at the time of the July 2009

RAC-ESF request. Capital spending is expected to slow slightly during the second half of the fiscal year, reflecting implementation constraints, and the government intends to slow the pace of spending on goods and services to achieve this target.

19. However, the government has recently taken a large loan that risks undermining fiscal performance in coming years. The government agreed with the Export-Import Bank of China on a concessional loan of US\$40 million (11 percent of GDP) for projects in education and infrastructure. About US\$24 million (7 percent of GDP) of the total would represent new expenditure and external financing not previously incorporated in the fiscal projections. $^{6}$ This expenditure and the existing financing pipeline from other creditors will imply a weakening in the primary surplus in the period FY2010/11-FY2012/13 during execution of the loan.

\footnotetext{
${ }^{5}$ The government is continuing with good-faith efforts to reach collaborative debt restructuring agreements with holdouts. The government will continue to make debt service payments into an escrow account at the ECCB on the terms of the restructured debt, in the event that holdouts agree to these terms.

${ }^{6}$ The terms of the loans are 2 percent interest, 5 years grace, and 20 years maturity, which imply a grant element of 36 percent.
} 
20. This deviation from the fiscal anchor will result in less favorable debt dynamics and may entail credibility costs. ${ }^{7}$ The mission encouraged the authorities to maintain a primary surplus of at least 1 percent of GDP during FY2010/11-FY2012/13, and to return to 3 percent thereafter. This policy would allow Dominica to reach the ECCB target of reducing the debt-to-GDP ratio to 60 percent by 2017 , one year later than anticipated at the time of the RAC-ESF request (July 2009), but still three years ahead of the ECCB's 2020 target date.

\section{Moreover, the government was considering a large additional loan from China} of US\$60 million (16 percent of GDP), which would be used to finance construction of a tourism resort. The mission noted that projects of this nature carry considerable commercial risks and uncertain rates of return, and are likely to be more successfully managed by the private sector. This particular project would likely prevent Dominica from reaching the ECCB debt-to-GDP target by 2020: only with a considerable positive impact of the resort project on GDP growth would the target would be reached (Appendix III). ${ }^{8}$ In addition to carefully considering the effects of additional borrowing on the debt trajectory, it will be of paramount importance to base their decision on a rigorous, independent assessment of the resort project's viability, to secure concessional terms, and to involve a private strategic partner. The authorities noted that they were already exploring potential partnership arrangements.

\section{The authorities are working to strengthen debt management and developing a} medium-term debt management strategy, with MCM assistance. ${ }^{9}$ Improved debt management is essential given the high level of indebtedness and the substantial risks to the current downward trajectory of debt ratios. The debt management strategy would improve institutional arrangements and build on the current approach that focuses on the less costly sources of financing; it would also contain a plan for managing financial risk and accessing grant financing. Staff suggested that the authorities also consider expanding the investor base cautiously via the ECCU's Regional Government Securities Market (RGSM) (Appendix IV).

\footnotetext{
7 The growth impact of the loan is uncertain as most materials would be imported and the investment in education is likely to take some time to yield a return.

${ }^{8}$ In this scenario, it is assumed that the project increases the rate of GDP growth by 0.3 percentage points in 2010-12, and by one percentage point in each of the five subsequent years.

${ }^{9}$ At the request of the authorities, an MCM mission visited Dominica during October 2009 to provide advice on debt management.
} 
23. The authorities are continuing with fiscal reforms. These comprise completing the income tax reform, improving tax administration, modernizing customs, and continuing to move towards a medium-term expenditure framework.

- Income tax reform. The final phase of a three-year income tax reform became effective on January 1, 2010. It has reduced personal income tax rates by 3 percentage points in each of the respective tax brackets. The revenue losses from the income tax reform have been lower than

Dominica: Income Tax Reform (In Eastern Caribbean dollars and percentages)

\begin{tabular}{lllrrr}
\hline Old Regime & \multicolumn{1}{c}{ New Regime from } & Jan-08 & Jan-09 & Jan-10 \\
\hline Non taxable allowance & 15,000 & 18,000 & 20,000 & 20,000 \\
Tax rate for each taxable income bracket & 20 & $1-20,000$ & 18 & 16 & 15 \\
$1-15,000$ & 30 & $20,001-50,000$ & 28 & 26 & 25 \\
$15,001-48,000$ & 40 & Over 50,001 & 38 & 36 & 35 \\
Over 48,000 & & & & &
\end{tabular}

Source: Ministry of Finance. expected originally — about 1 percent of GDP each year in FY 2007/08 and FY 2008/09.

- Tax administration reform. Although tax administration capacity is strong, as evidenced by the performance of the VAT, broader tax administration reforms are still needed. In this context, the authorities are reorganizing the Inland Revenue Department (IRD) in phases, focusing on creating a large and medium-sized taxpayer unit in the first phase and a planning unit and small taxpayer unit in phases two and three. The proposed reform strategy aims at implementing a new organizational structure where operations are integrated, and audit and enforcement activities are organized separately for large/medium and small taxpayers, with the goal of achieving higher efficiency and a lower compliance burden.

- Customs administration reform. Passage of a new Customs Act and a major upgrade to the customs IT infrastructure, to ASYCUDA World, will allow risk-based inspections and electronic manifests and signatures, leading to reduced clearance times. Duty-free concessions which had been approved by cabinet will now be processed at customs, which will provide reports on concessions granted and duties foregone.

- Medium-term expenditure framework (MTEF). The government would continue to move towards a MTEF to improve predictability of capital expenditure and its consistency with the medium-term fiscal objectives. The budget already incorporates projections over a three-year horizon. 
24. Further action is needed to strengthen Dominica Social Security (DSS), which is burdened by an aging and shrinking population and very high labor force emigration. ${ }^{10}$ In this regard, a package of reforms was announced in 2007 to improve the sustainability of the DSS, including an immediate rise in contribution rates. However, several other key measures announced in 2007 were not implemented as planned in January 2009, including an increase in the retirement age from 60 to 61 and a second round of increases in contribution rates. The government decided instead, in the context of the global financial crisis, to wait for the results of the tenth actuarial review to be completed shortly. The authorities restated the high importance they attach to ensuring the sustainability of the DSS.

\section{B. Financial Sector Policies}

\section{A committee appointed by the ECCU governments is discussing with strategic} investors the establishment of a new company to take over BAICO's operations in the region. The strategy comprises a regional solution, which would transfer the property insurance portfolio to an existing insurance company and establish a Medical Claims Support Fund. Finding sufficient funds to capitalize the new company will be a challenge, and haircuts or a rephasing of payments are likely to be part of the solution. ${ }^{11}$ The mission recommended that the resolution of BAICO adhere to three principles: (i) avoiding systemic contamination; (ii) minimizing the fiscal costs to the extent possible, given the region's high debt levels and related vulnerabilities; and (iii) giving priority to claims up to a low threshold to protect vulnerable groups. The financial difficulties of CLICO Barbados are a significant concern, and the authorities are monitoring developments closely.

\section{The collapse of the CL Financial Group and large role played by credit unions} underscore the need to strengthen the recently established Financial Services Unit (FSU), the Single Regulatory Unit for the nonbank financial sector. ${ }^{12}$ Indeed, one credit union is larger than all but two commercial banks, and nonperforming loans of credit unions were 8.7 percent of total assets as of end-June 2009. In addition, some smaller institutions have significant exposure to the CL Financial Group. In the context of regional efforts to establish an all-encompassing regulatory framework, the FSU should be made fully operational through supporting legislation; adequate staffing; capacity building; and on-site examination of insurance companies and credit unions. The authorities are working to enact

\footnotetext{
${ }^{10}$ See Hunter Monroe, “Can the ECCU Afford to Grow Old?”, IMF Working Paper 09/38.

${ }^{11}$ To date, the Trinidad and Tobago government has contributed US\$50 million and ECCU governments are expected to contribute US\$75 million to the capitalization of this new company.

${ }^{12}$ A Ponzi scheme, SGL Holdings, operated briefly in Dominica but did not grow as large as in several other Caribbean jurisdictions. See Ana Carvajal, Hunter Monroe, Catherine Pattillo, and Brian Wynter, "Ponzi Schemes in the Caribbean,” IMF Working Paper 09/95.
} 
updated harmonized legislation on insurance, credit unions, and money services, which will strengthen capital, prudential, and other requirements, as well as the FSU's ability to enforce them. It is also important for the authorities to work closely with the ECCB to improve bank supervision, including more frequent on-site examinations. In light of the CL Financial experience, it will be important to ensure that insurance companies place assets under trusteeship in their statutory funds to back up local insurance liabilities. The mission advised keeping the SDR allocation (SDR 7.2 million) as a shared buffer for ECCU members against risks stemming from potential stress in financial systems in the region.

27. The Agricultural and Industrial Development Bank has been refocused on its original mandate as a development bank and placed under the supervision of the FSU. It no longer takes deposits or makes consumer loans and has reduced its large portfolio of nonperforming loans (NPLs). The bank's lending has recently grown rapidly, and it has contracted loans amounting to US\$22.4 million (6 percent of GDP) to finance its operations. The mission emphasized the need for close monitoring due to the potential contingent fiscal liabilities and recommended an on-site examination by the FSU.

\section{Medium-Term Outlook}

28. Medium-term growth prospects are expected to be driven by industries related to the environment, water and energy sources. Comparative advantages in some natural resource-based industries should be better exploited as in the case of eco-tourism, agroindustries, niche focused agriculture and fisheries, and geothermal energy.

29. The authorities have made significant progress with measures aimed at improving competitiveness, easing infrastructure bottlenecks, and reducing the costs of doing business. The government has intensified its focus on building infrastructure such as roads, airport, and seaports. Nevertheless, Dominica's Doing Business ranking has slipped recently, reflecting faster progress in other countries.

30. Continuing the rapid pace of structural reforms will be necessary for the authorities to achieve their medium-term annual growth objective of 3 percent. In particular, the mission recommended:

- $\quad$ Formulating and implementing a national export strategy and facilitating the diversification of agricultural exports from bananas towards agro-industries and high value specialty crops, which have grown rapidly in recent years. Higher quality standards would also facilitate maintaining a presence in certain markets, and improved land titling will facilitate financing.

- $\quad$ Exploiting geothermal energy resources, which could reduce electricity costs and be exported to neighboring islands.

- Emphasizing infrastructure investments complementary to Dominica's other comparative advantages, for instance, in off-shore education and cruise tourism. 
- Undertaking other measures to improve the business environment, including continuing to improve customs clearance and contract enforcement.

\section{Statistical Issues}

31. The Central Statistical Office has improved the compilation of national accounts with assistance from CARTAC. However, GDP may be underestimated due to incomplete information provided by an offshore university - one of the largest employers - and the mission encouraged the authorities to redouble efforts to obtain this information. ${ }^{13}$

\section{Staff ApPraisal}

32. Dominica's prudent fiscal policy in recent years has improved its debt sustainability in the context of an appropriately focused development strategy. After the 2001-02 crisis, Dominica has put its finances in order by introducing a VAT, containing expenditure, and undertaking a successful debt restructuring. The FY 2008/09 fiscal outturn was far better than expected despite high reconstruction spending and the lowering of income tax rates in the context of a three-stage income tax reform. As a result, debt ratios have declined markedly. The country has thus deservedly acquired a solid reputation for good fiscal management. At the same time, the Growth and Social Protection Strategy sets forth a clear strategy for fostering growth, and the government has made notable progress in implementing its key elements.

33. The prudent fiscal stance of the last several years created the space for the government's response to the global downturn. The government was able to maintain capital spending in 2009 at a high level, which - coupled with Dominica's lesser dependence on tourism - helped moderate the impact of the adverse external shock. However, the continuing strong performance of the VAT allowed the government to maintain its target of 3 percent of GDP for the primary surplus thus far.

\section{Looking forward, fiscal policy will need to target further reducing the public} debt ratio and maintaining room for maneuver in response to natural disasters and external shocks. To help them achieve these objectives, the authorities are considering a welcome set of additional fiscal reforms, including further improvements in tax administration and modernization of customs. Staff believes that these reforms will not only enhance the public finances in the coming years but will also improve the business environment. In parallel, debt management should be enhanced in light of the still high public debt ratios.

\footnotetext{
${ }^{13}$ When a similar institution in Grenada began providing information for the compilation of national accounts, 2006 GDP was revised upward by 7 percent.
} 
35. However, large forthcoming projects financed by China risk slowing significantly the downward trajectory for the public debt-to-GDP ratio. While the associated departure from the anchor of a 3 percent of GDP primary surplus is expected to be temporary, it will significantly affect the debt dynamics and may entail credibility costs. Staff therefore urges the authorities to return to the fiscal anchor as soon as possible. Furthermore, the expenditure that was being contemplated on a large new tourism resort also carries considerable commercial risks which may be better managed by the private sector. Hence, it will be essential for the government to base its decision to obtain a rigorous, independent assessment, to obtain concessional terms, and - if it proceeds - to involve a private strategic partner.

36. Improved nonbank supervision is essential to limit financial vulnerabilities. The resolution of BAICO should proceed promptly, avoiding systemic spillovers while minimizing fiscal costs to the extent possible. Furthermore, the authorities should continue to monitor closely developments with CLICO, given its financial difficulties. Strengthening the work of the FSU is essential, for instance, through on-site examinations of insurance companies and credit unions.

37. The staff welcomes the reform of the AID Bank. The bank is now appropriately focused on its role as a development bank and no longer takes deposits or makes consumer loans. Notwithstanding the reduction of its NPLs, the rapid rate of portfolio growth and large amount of loans recently contracted by the bank are a significant concern. An on-site examination by the FSU would help ensure that the bank's resources are well allocated.

38. Recent progress with structural reforms has been notable. Dominica is ahead of many neighboring countries with reforms to improve customs processing, land registration, and contract enforcement. Expanded airport facilities will soon improve Dominica's accessibility. Nevertheless, sustained and deepened structural reforms will be critical to achieving the targeted level of growth. The medium-term growth challenge is to manage the transition from bananas to tourism and diversified agro industries, and to foster private sector-led growth and poverty reduction.

39. The statistics provided by the Dominican authorities are generally adequate for Fund surveillance, although areas for improvement remain. In particular, the authorities are encouraged to address the possible underestimation of GDP.

40. It is expected that the next Article IV consultation with Dominica will take place on the standard 12-month cycle. 
Appendix I

Impact of the Global Crisis on the Eastern Caribbean Currency Union

The ECCU has been severely impacted by the global slowdown. Real regional GDP is expected to contract by about 6 percent in 2009, down from positive growth of 2 percent in 2008, reflecting a collapse in tourist arrivals and FDI-financed construction activity. A slow recovery is expected with growth only in 2011.

A regional currency board arrangement and high public debt levels $(90$ percent of GDP at end 2008) limit regional authorities' fiscal policy responses to the current downturn. Government revenue losses induced by the economic slowdown and higher debt-servicing costs are projected to raise the region's overall fiscal deficit to 9 percent of GDP in 2009 from 3 percent in 2008.

The global financial crisis has exposed weaknesses in the ECCU's financial sector. Although the presence of international banks has offered an important source of stability, some indigenous banks have significant exposures to government debt. Rising NPLs and tightening of liquidity pose increasing concerns about the stability of the banking system. Problems in the insurance sector related to the CL Financial Group have not yet been resolved, despite some progress toward a regional solution.

The ECCB Monetary Council adopted an "Eight Point Stabilization and Growth Program" in April 2009 as the basis for developing a coordinated regional response to the economic downturn, covering financial programs, fiscal reforms, debt management, PSIP, social and financial safety nets, and reforms of indigenous banks and the insurance sector.

The reserves of the ECCB were at a comfortable level at end 2009, reflecting Fund financial assistance and SDR allocations. Gross international reserves stood at US\$895 million at end 2009 (5.2 months of imports), compared to US\$759 million at end 2008 (3.4 months of imports). 


\section{Appendix II}

\section{Exchange Rate and Competitiveness Assessment}

External competitiveness does not appear to be an issue. As can be seen by the charts below, the CPI-based REER has been on a declining trend, as have customerand competitor-based REER measures. Several methods are used below to assess the level of the real exchange rate. ${ }^{1 /}$
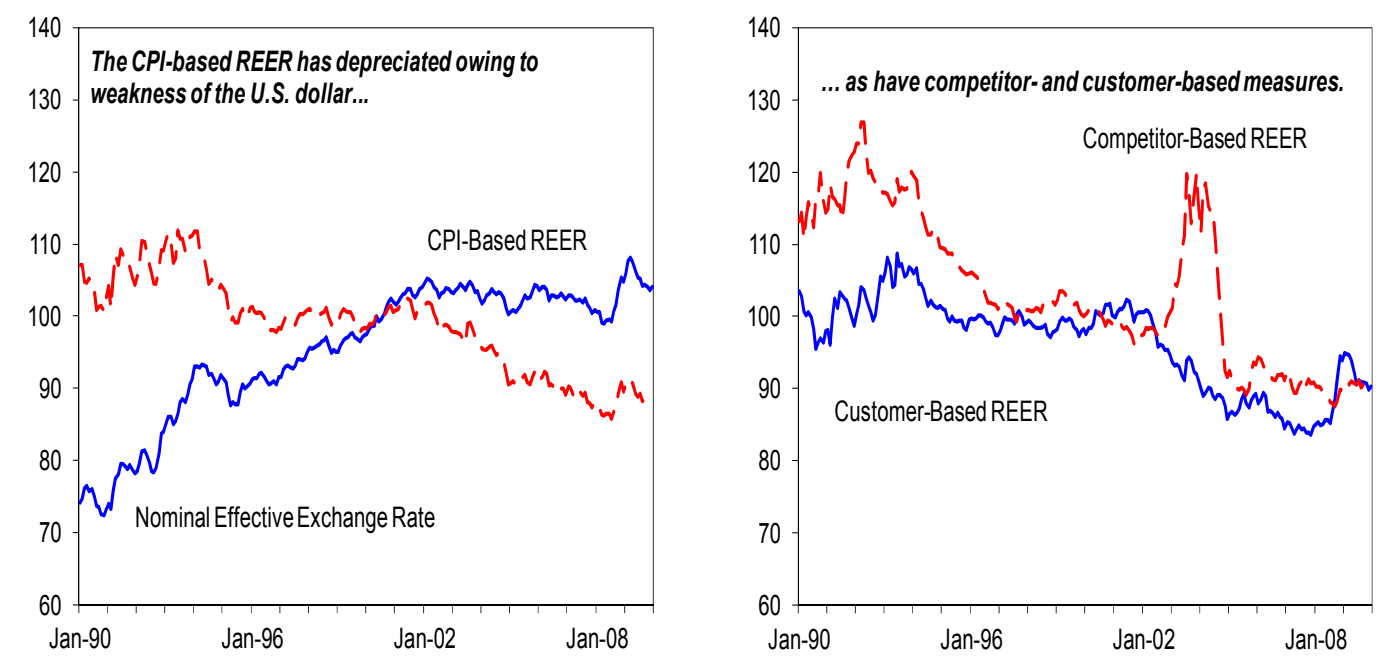

- $\quad$ The Purchasing Power Parity (PPP) hypothesis approach suggests that the real exchange rate was undervalued at end 2008. The PPP hypothesis is a starting point to provide a benchmark for the equilibrium real exchange rate. Based on this analysis the real exchange rate was undervalued by 9 percent at end 2008 .

\section{- The REER was slightly} undervalued at end 2008 based on the fundamentalsbased approach. The fundamentals-based approach explores the sources of real exchange rate fluctuations, and determines nominal misalignments by distinguishing the factors that affect the long-run real exchange rate from those that may cause

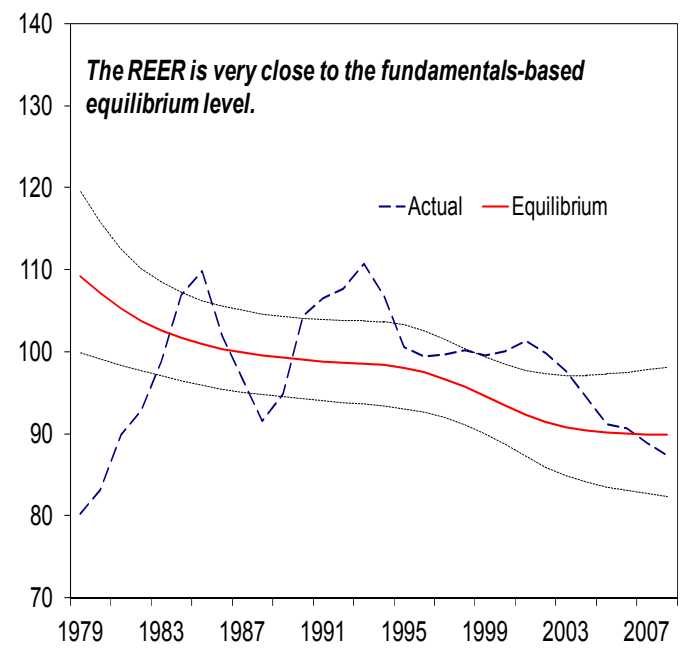
short-run misalignments. 
This econometric analysis takes into account productivity differentials, terms of trade, government consumption, and net foreign assets. According to this approach, Dominica's REER was below the equilibrium level by around 2 percent at end 2008.

\section{- The macroeconomic balance} approach indicates an overvaluation of the REER.

The macroeconomic balance approach is used to estimate an equilibrium current account or current account "norm". This approach calculates the difference between the current account balance projected over the medium term at the prevailing exchange rate, and an

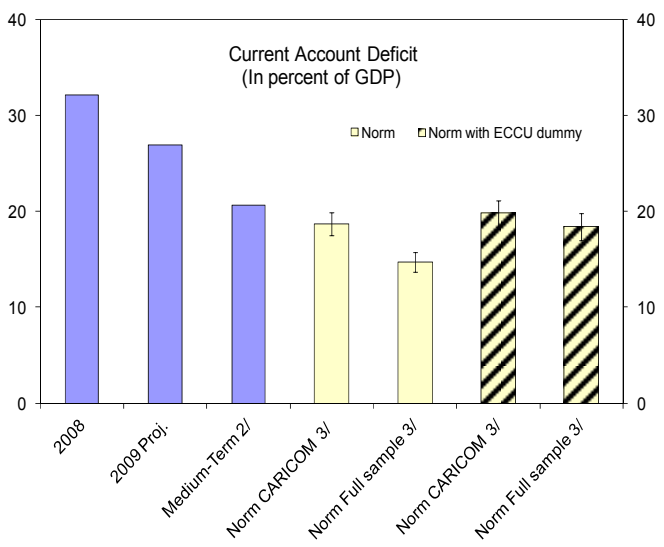
estimated current account norm.

If the current account deficit projected over the medium term exceeds the estimated equilibrium, there is evidence of overvaluation. The current account norm is determined through regression analysis where the fiscal balance, the oil balance, relative income, relative economic growth, FDI, and grants are the explanatory variables. Dominica's projected medium term deficit is 20.6 percent of GDP, above the norm by around 2.6 percent when using either (i) a sample of CARICOM countries, or (ii) an extended sample of tourism dependent countries in the regression analysis. This implies an overvaluation in the REER of 7 percent.

- $\quad$ The World Bank's Doing

Business Indicators (2010) suggest that Dominica's overall business environment is not as strong as the other ECCU countries. It ranked $83^{\text {rd }}$ among 183 countries in the full sample, and $15^{\text {th }}$ out of 32 countries in the Latin American and Caribbean region. Dominica ranks well within the LAC region in the areas of starting a business $\left(5^{\text {th }}\right)$, protecting investors $\left(5^{\text {th }}\right)$, and

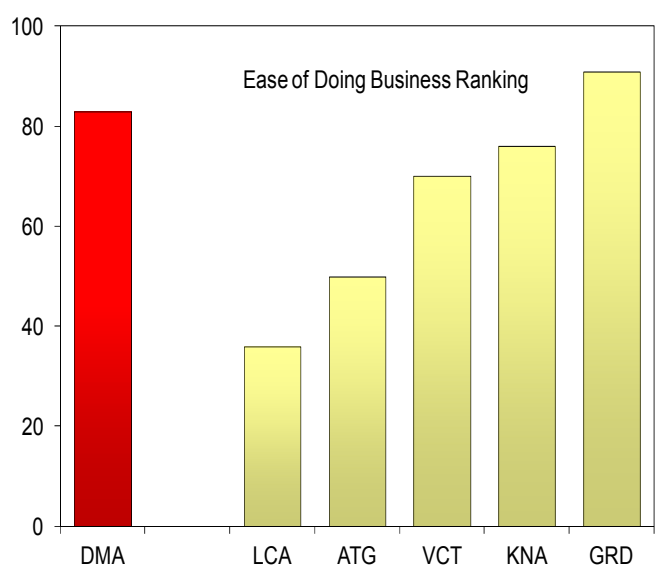
dealing with construction permits $\left(7^{\text {th }}\right)$, but poorly in enforcing contracts and closing business ( $28^{\text {th }}$ respectively). Dominica ranks $26^{\text {th }}$ among 42 countries among upper 
middle income countries, and $34^{\text {th }}$ among 61 countries with small populations. Relative to 2009, Dominica's ranking has deteriorated in almost all the indicators reflecting faster progress in other countries.

- Dominica's share of ECCU and Caribbean stayover arrivals has increased in recent years, with particularly strong growth in its share of ECCU arrivals, indicating competitiveness may be improving.

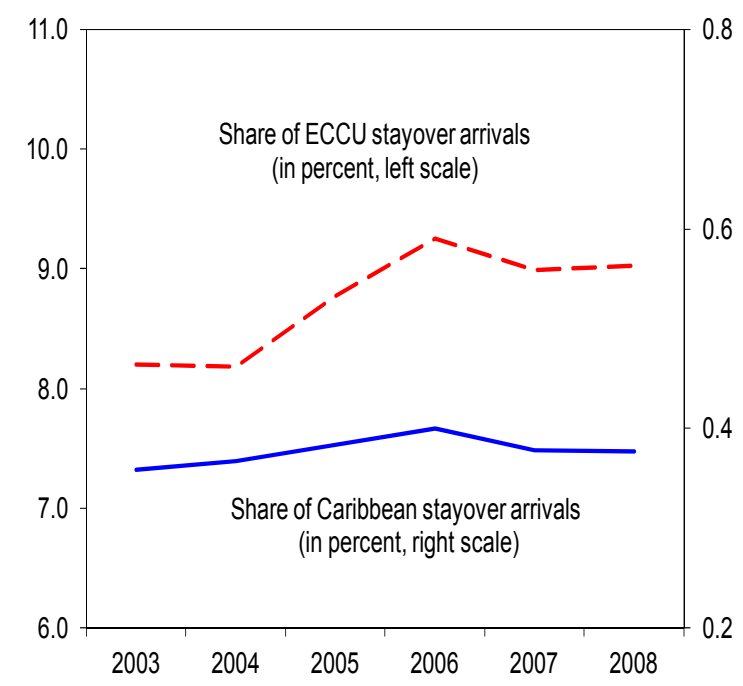

1/ See Cashin, Pineda, and Sun (2009), International Monetary Fund WP/09/78.

2/ Based on Fund staff estimates. Medium-term is 2015.

3/ Based on data through 2008. 


\section{Appendix III}

\section{Debt Sustainability Analysis (DSA)}

The updated DSA shows some deterioration relative to the previous exercise. ${ }^{1}$ The previous baseline scenario assumed: (i) real GDP growth of 3 percent annually over the medium term; and (ii) a primary fiscal surplus of at least 3 percent of GDP from FY 2010/11 onwards. In that scenario, Dominica would reach the ECCB target of 60 percent for the debt-to-GDP ratio in 2016, four years ahead of the ECCB's 2020 target. In the new baseline scenario, the US $\$ 40$ million loan from China reduces the primary surplus to only 1.3 percent of GDP during FY 2010/11 to FY 2012/13, and the primary surplus remains at 3 percent of GDP thereafter. Under these assumptions, and maintaining the same real GDP growth rate, the public debt ratio would reach the 60 percent of GDP target in 2017, one year later than before.

Risks to the debt sustainability outlook. The projected real GDP growth and revised path for the primary surplus are subject to several downside risks:

- Proposed large new borrowing. The government was considering an additional loan from China of US\$60 million (16 percent of GDP) for a tourism resort. The additional borrowing would prevent Dominica from achieving the ECCB target by 2020 without a strong growth impact. Also, the new borrowing would increase the PV of debt-to-GDP ratio in 2010-14 above the 50 percent threshold. Assuming a considerable positive impact of the resort project on GDP growth, the 60 percent target level would be reached in 2020 .

- Vulnerability to external shocks and natural disasters. Commodity price shocks, downturns in tourism, and hurricanes (like those in the last two consecutive years) could slow growth and undermine the fiscal position.

- Volatility of grant inflows. The projected grant financing at around 6.6 percent of GDP over the medium term implies a decline from the average of 12 percent in 2007-08, but is still higher than the historical average of close to 5 percent for $1990-2006 .{ }^{2}$ In the event that grant inflows were lower than expected, capital expenditure would need to be scaled back further to keep the debt-to-GDP ratio on a downward trajectory.

- Degree of concessionality. Multilateral borrowing is assumed to be available on concessional terms, reflecting current Caribbean Development Bank lending policies for small countries like Dominica.

- Possible contingent liabilities. The large capital shortfall of the CL Financial insurance subsidiaries could represent a large potential contingent liability.

\footnotetext{
${ }^{1}$ See IMF Country Report No. 09/293.

${ }^{2}$ The government has taken steps in recent years to diversify its trade and economic cooperation linkages, especially with China and Venezuela, which has resulted in increased aid flows (see Box 5, in IMF Country Report No. 08/310.
} 


\section{Appendix IV}

\section{Debt Management}

Dominica's high public debt level, coupled with its vulnerability to external shocks, natural disasters and regional financial risks, presents a substantial risk to the economy and challenges to long-term debt sustainability. At the request of the authorities, an MCM mission visited Dominica in October 2009 and provided advice on how to address these risks, including developing a medium-term debt management strategy and implementing measures to strengthen debt management capacity and institutional arrangements. The key recommendations were:

- $\quad$ Pursue debt sustainability vigilantly. While the public debt ratio has been falling and is set to continue its downward trajectory on staff's baseline assumptions, substantial risks remain. Recent experience shows that debt sustainability could unwind very rapidly - the debt stock almost doubled in five years to about 130 percent of GDP in 2003, before undergoing a debt restructuring. Prudent fiscal policies and debt management would have to be pursued vigorously to maintain the downward path of the debt to GDP ratio. In this context, the control of public corporations and the management of their guaranteed debt should be strengthened, allowing the government to minimize potential shocks to its balance sheet arising from guarantees being called. In the near-term, the government should avoid an aggressive accumulation of debt, including the build-up of concessional debt, as this could jeopardize the gains made in controlling the public debt.

- Strengthen debt management capacity and institutional arrangements. It is important to develop the capacity to analyze, manage and control debt and guarantees. Improvements are needed in debt data recording and introduction of procedures to require public corporations to supply information such as debt data and disbursement plans. Over the next year, further reforms, including development of operational risk management, the introduction of a Code of Conduct and a staff training program should be implemented. Consideration should also be given to introducing a public debt law. A Public Debt Committee, chaired by the Minister of Finance, with the participation of the ECCB as appropriate, should be established, with responsibility for approving the debt strategy and the associated annual financing plan.

- Implement a medium-term debt management strategy. As a first step, the government should identify clear debt management objectives, and formulate and implement a mediumterm debt management strategy aimed at meeting these objectives. As the high level of debt restricts the government's access to commercial borrowing, this strategy should, building on the current approach, emphasize the reliance on grants and concessional sources of financing, and would also need to contain a clear plan for managing refinancing risk.

- $\quad$ Seek cautiously to expand the investor base via the Regional Government Securities Market (RGSM). The RGSM provides a good platform to expand the investor base, to reduce costs, and possibly to refinance maturing restructured Eastern Caribbean dollar bonds should that be necessary. However, this should be approached cautiously, seeking first to establish a presence with small volumes of short maturity securities, which could be expanded over time. 
Table 1. Dominica: Selected Economic and Social Indicators

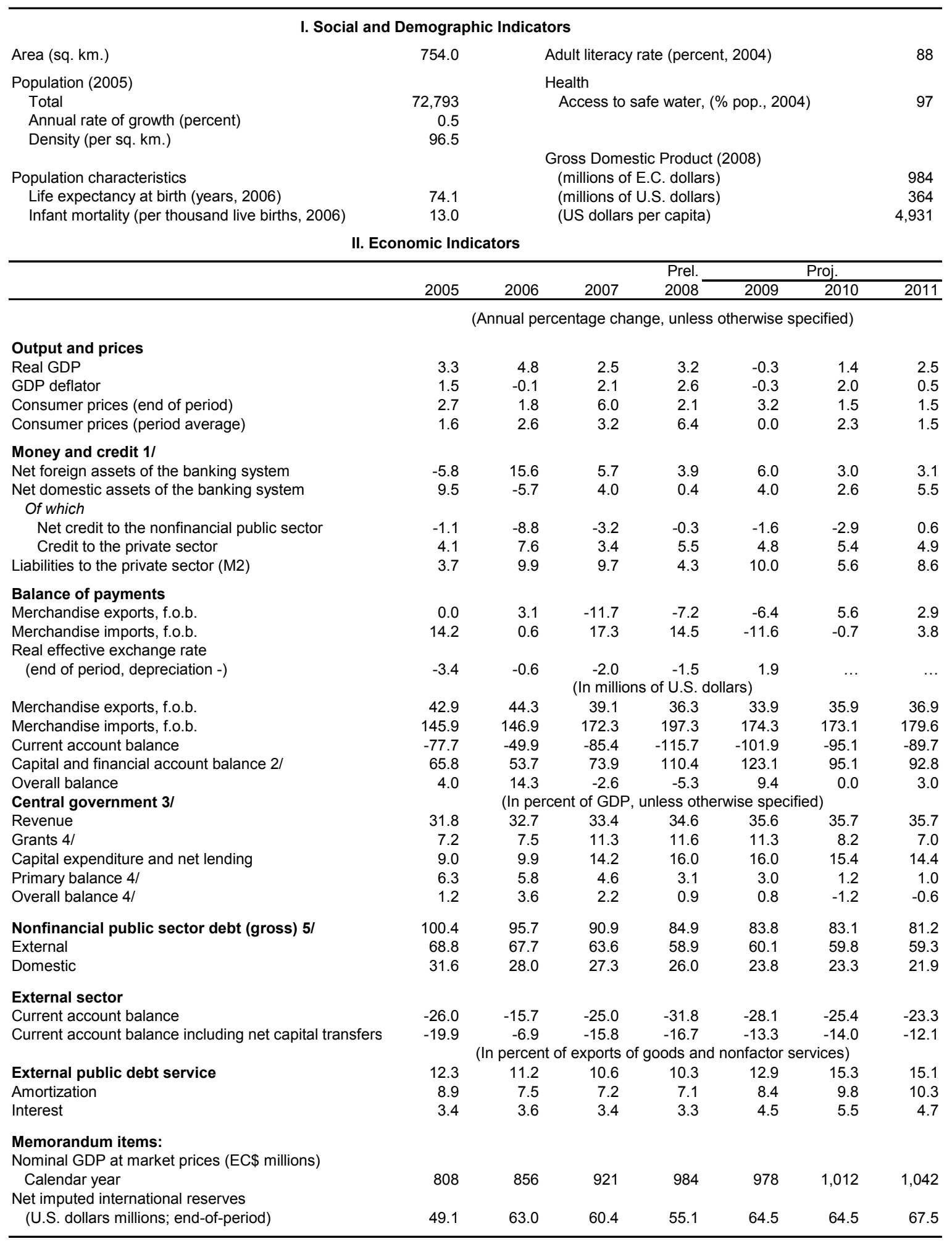

Sources: Dominican authorities; Eastern Caribbean Central Bank (ECCB); and Fund staff estimates and projections.

$1 /$ Change relative to the stock of M2 at the beginning of the period.

2/ Including errors and omissions.

$3 /$ Fiscal year (July-June) basis. Figures shown for a given calendar year relate to the fiscal year beginning on July 1 of that year.

4/ Does not include grants that were received but not spent.

$5 /$ Includes central government liabilities to Dominica Social Security. 
Table 2. Dominica: Summary Accounts of the Central Government 1/

\begin{tabular}{|c|c|c|c|c|c|c|c|}
\hline & \multicolumn{4}{|r|}{ Est. } & \multicolumn{3}{|c|}{ Proj. } \\
\hline & $2005 / 06$ & $2006 / 07$ & $2007 / 08$ & $2008 / 09$ & $2009 / 10$ & $2010 / 11$ & $2011 / 12$ \\
\hline & \multicolumn{7}{|c|}{ (In millions of Eastern Caribbean dollars) } \\
\hline Total revenue and grants & 325.0 & 357.4 & 425.8 & 453.2 & 466.2 & 450.9 & 455.6 \\
\hline Current revenue & 263.2 & 289.8 & 317.2 & 339.1 & 353.8 & 366.4 & 380.1 \\
\hline Tax revenue & 239.5 & 262.4 & 289.3 & 313.7 & 316.5 & 327.9 & 340.3 \\
\hline Taxes on income & 52.7 & 53.7 & 52.5 & 54.8 & 50.6 & 52.3 & 54.2 \\
\hline Taxes on property & 7.9 & 7.2 & 10.0 & 10.9 & 8.2 & 8.5 & 8.8 \\
\hline Taxes on domestic goods and services & 82.1 & 146.9 & 164.1 & 179.5 & 183.9 & 191.1 & 198.3 \\
\hline Taxes on international trade and transactions & 96.7 & 54.6 & 62.7 & 68.6 & 73.8 & 76.1 & 78.9 \\
\hline Nontax revenue & 23.7 & 27.4 & 27.9 & 25.4 & 37.3 & 38.4 & 39.9 \\
\hline Capital revenue & 1.5 & 0.9 & 0.8 & 0.3 & 0.3 & 0.3 & 0.3 \\
\hline Grants 2/ & 60.3 & 66.7 & 107.8 & 113.8 & 112.1 & 84.2 & 75.1 \\
\hline Total expenditure & 315.3 & 325.3 & 404.5 & 444.3 & 457.9 & 463.1 & 462.5 \\
\hline Current expenditure & 240.2 & 237.6 & 269.1 & 287.0 & 298.7 & 305.1 & 309.5 \\
\hline Wages and salaries & 105.3 & 113.4 & 117.7 & 123.5 & 127.3 & 131.1 & 136.0 \\
\hline Interest & 43.0 & 19.9 & 22.7 & 21.9 & 21.1 & 24.0 & 17.9 \\
\hline Domestic & 20.2 & 7.1 & 11.7 & 5.8 & 6.1 & 5.5 & 5.4 \\
\hline External & 22.8 & 12.7 & 11.0 & 16.0 & 15.0 & 18.5 & 12.5 \\
\hline Goods and services & 45.7 & 46.7 & 70.5 & 78.1 & 81.3 & 78.7 & 81.6 \\
\hline Transfers and subsidies & 46.2 & 57.6 & 58.3 & 63.6 & 69.1 & 71.3 & 74.0 \\
\hline Capital expenditure and net lending & 75.2 & 87.7 & 135.3 & 157.3 & 159.1 & 158.0 & 153.0 \\
\hline Fixed investment & 78.2 & 90.4 & 136.7 & 158.3 & 160.0 & 158.0 & 153.0 \\
\hline Net equity, net lending, and transfers & -3.0 & -2.7 & -1.4 & -1.1 & -0.9 & 0.0 & 0.0 \\
\hline Primary balance & 52.6 & 52.0 & 44.0 & 30.8 & 29.5 & 11.9 & 11.0 \\
\hline Overall balance (excluding grants) & -50.7 & -34.7 & -86.5 & -104.9 & -103.8 & -96.4 & -82.0 \\
\hline Overall balance & 9.6 & 32.1 & 21.4 & 9.0 & 8.4 & -12.1 & -6.9 \\
\hline Statistical discrepancy & 4.9 & -5.4 & -3.3 & 0.1 & 0.0 & 0.0 & 0.0 \\
\hline Financing & -14.6 & -26.6 & -18.1 & -9.1 & -8.4 & 12.1 & 6.9 \\
\hline Net external financing & 9.1 & -10.8 & -11.2 & -8.9 & 25.6 & 25.8 & 28.1 \\
\hline Disbursements & 7.5 & 2.9 & 3.9 & 7.7 & 47.9 & 54.7 & 59.4 \\
\hline Amortization & 20.4 & 13.1 & 14.8 & 16.6 & 22.3 & 29.0 & 31.2 \\
\hline Other (including rescheduling/arrears) & 22.0 & -0.6 & -0.4 & 0.0 & 0.0 & 0.0 & 0.0 \\
\hline Net domestic financing & -23.7 & -15.8 & -6.9 & -0.1 & -33.9 & -13.6 & -21.2 \\
\hline Bank 3/ & -16.4 & -7.7 & 8.5 & -1.8 & -33.9 & -13.6 & -21.2 \\
\hline Nonbank & -6.6 & -5.7 & -14.0 & 3.1 & 0.0 & 0.0 & 0.0 \\
\hline Other (including rescheduling/arrears) & -0.7 & -2.4 & -1.3 & -1.4 & 0.0 & 0.0 & 0.0 \\
\hline \multicolumn{8}{|l|}{ Memorandum items: } \\
\hline Nominal GDP at market prices & 832 & 889 & 952 & 981 & 995 & 1,027 & 1,065 \\
\hline Nonfinancial public sector debt & 835 & 850 & 866 & 833 & 834 & 853 & 865 \\
\hline External & 573 & 601 & 606 & 578 & 598 & 614 & 631 \\
\hline Domestic & 263 & 249 & 260 & 255 & 236 & 239 & 234 \\
\hline
\end{tabular}

Sources: Ministry of Finance; and Fund staff estimates and projections.

1/ Fiscal year (July-June) basis.

2/ Does not include grants that were received but not spent.

$3 /$ Includes monetary authorities and commercial banks. 
Table 3. Dominica: Summary Accounts of the Central Government 1/

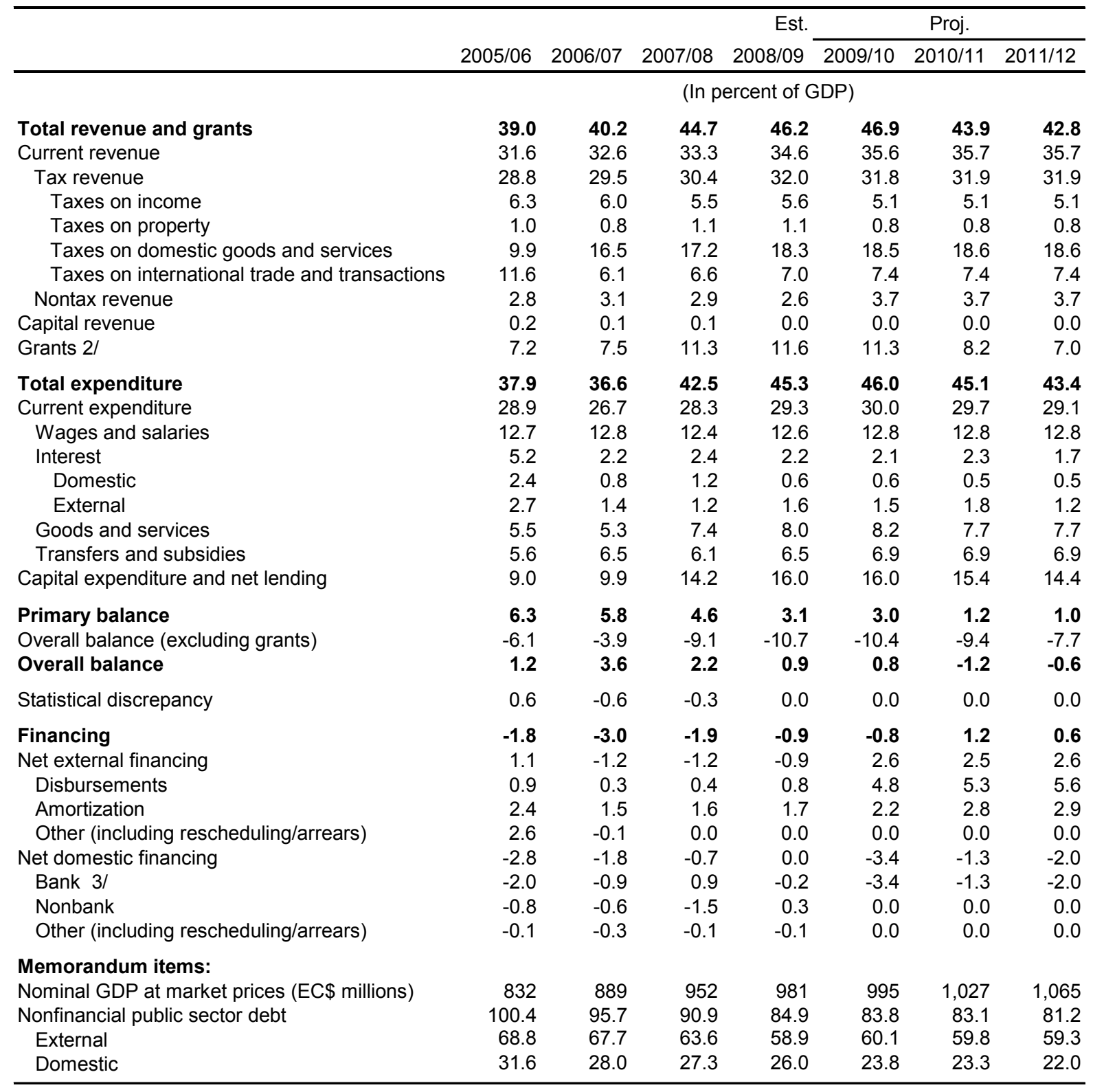

Sources: Ministry of Finance; and Fund staff estimates and projections.

$1 /$ Fiscal year (July-June) basis.

2/ Does not include grants that were received but not spent.

$3 /$ Includes monetary authorities and commercial banks. 
Table 4. Dominica: Balance of Payments

\begin{tabular}{|c|c|c|c|c|c|c|c|c|c|c|c|}
\hline & & & & Prel. & & & & Proj. & & & \\
\hline & 2005 & 2006 & 2007 & 2008 & 2009 & 2010 & 2011 & 2012 & 2013 & 2014 & 2015 \\
\hline & \multicolumn{11}{|c|}{ (In millions of U.S. dollars) } \\
\hline Current account balance & -77.7 & -49.9 & -85.4 & -115.7 & -101.9 & -95.1 & -89.7 & -92.7 & -96.0 & -94.5 & -94.9 \\
\hline Trade balance & -103.0 & -102.6 & -133.3 & -161.0 & -140.3 & -137.3 & -142.8 & -149.2 & -156.1 & -159.8 & -165.5 \\
\hline $\begin{array}{l}\text { Exports (f.o.b.) 1/ } \\
\text { Of which }\end{array}$ & \multicolumn{10}{|c|}{ Of which } & 42.7 \\
\hline Bananas & 6.4 & 7.5 & 5.2 & 5.1 & 5.3 & 6.4 & 6.2 & 5.9 & 5.6 & 5.3 & 5.1 \\
\hline $\begin{array}{l}\text { Imports (f.o.b.) } \\
\text { Of which }\end{array}$ & 145.9 & 146.9 & 172.3 & 197.3 & 174.3 & 173.1 & 179.6 & 187.5 & 196.1 & 201.0 & 208.1 \\
\hline Mineral fuels & 19.3 & 22.7 & 25.8 & 36.0 & 28.7 & 35.7 & 39.4 & 42.0 & 44.1 & 46.5 & 49.3 \\
\hline Services balance & 36.3 & 48.2 & 43.3 & 33.1 & 30.0 & 34.8 & 40.8 & 43.4 & 46.1 & 50.3 & 54.3 \\
\hline Exports of services & 86.4 & 100.2 & 108.8 & 108.3 & 96.7 & 101.3 & 110.0 & 115.9 & 122.1 & 128.4 & 135.5 \\
\hline Tourism receipts & 57.0 & 71.7 & 74.5 & 71.6 & 60.2 & 63.5 & 71.1 & 75.2 & 79.6 & 84.0 & 89.1 \\
\hline Other & 29.4 & 28.5 & 34.4 & 36.7 & 36.5 & 37.8 & 38.9 & 40.7 & 42.5 & 44.4 & 46.4 \\
\hline Imports of services & 50.2 & 52.0 & 65.5 & 75.2 & 66.7 & 66.5 & 69.2 & 72.5 & 76.0 & 78.2 & 81.2 \\
\hline Net income & -30.6 & -15.0 & -16.1 & -16.9 & -19.1 & -20.7 & -18.6 & -19.3 & -19.8 & -20.2 & -20.6 \\
\hline Of which: Interest payments (public sector) & -10.7 & -5.2 & -4.7 & -4.8 & -7.0 & -8.1 & -5.7 & -5.8 & -5.7 & -5.5 & -5.2 \\
\hline Net current transfers & 19.7 & 19.6 & 20.6 & 29.2 & 27.5 & 28.1 & 30.9 & 32.3 & 33.7 & 35.3 & 36.9 \\
\hline Private & 19.4 & 19.3 & 21.0 & 29.2 & 23.9 & 28.1 & 30.9 & 32.3 & 33.7 & 35.3 & 36.9 \\
\hline Public & 0.2 & 0.3 & -0.3 & 0.0 & 3.6 & 0.0 & 0.0 & 0.0 & 0.0 & 0.0 & 0.0 \\
\hline Capital and financial account & 65.8 & 53.7 & 73.9 & 110.4 & 123.1 & 95.1 & 92.8 & 96.6 & 100.4 & 99.0 & 99.5 \\
\hline Capital account & 18.3 & 28.0 & 31.4 & 54.8 & 53.8 & 42.7 & 43.1 & 42.2 & 43.8 & 45.8 & 47.9 \\
\hline Public capital transfers & 15.2 & 24.8 & 28.2 & 51.2 & 50.1 & 38.9 & 39.2 & 38.2 & 39.6 & 41.4 & 43.3 \\
\hline Private capital transfers & 3.1 & 3.1 & 3.2 & 3.6 & 3.6 & 3.7 & 3.9 & 4.0 & 4.2 & 4.4 & 4.6 \\
\hline Financial account & 47.5 & 25.8 & 42.5 & 55.6 & 69.3 & 52.4 & 49.7 & 54.4 & 56.6 & 53.2 & 51.7 \\
\hline Public sector & -3.8 & -4.1 & -3.0 & -5.0 & -0.5 & 5.9 & 6.2 & 5.0 & -0.2 & -7.5 & -11.4 \\
\hline Budgetary flows (net) & -3.8 & -2.1 & -4.8 & -6.4 & -0.7 & 5.6 & 5.9 & 5.0 & -0.2 & -7.5 & -11.4 \\
\hline Disbursements & 7.8 & 1.5 & 5.9 & 3.8 & 10.3 & 19.0 & 21.1 & 21.0 & 16.1 & 11.2 & 8.7 \\
\hline Repayments & 11.5 & 3.6 & 10.7 & 10.2 & 11.0 & 13.4 & 15.2 & 16.1 & 16.3 & 18.7 & 20.1 \\
\hline Nonbudgetary flows (net) & 0.0 & -2.0 & 1.7 & 1.4 & 0.3 & 0.3 & 0.3 & 0.0 & 0.0 & 0.0 & 0.0 \\
\hline Private sector & 51.2 & 29.8 & 45.6 & 60.6 & 69.8 & 46.5 & 43.4 & 49.4 & 56.8 & 60.7 & 63.1 \\
\hline Direct investment & 19.2 & 25.9 & 53.2 & 59.9 & 29.0 & 34.2 & 38.3 & 43.7 & 49.2 & 53.0 & 55.2 \\
\hline Commercial banks & 8.8 & -12.4 & -18.8 & -17.6 & -10.3 & -10.8 & -8.8 & -8.4 & -8.2 & -8.1 & -8.0 \\
\hline Other private flows & 23.2 & 16.4 & 11.2 & 18.3 & 39.4 & 23.1 & 14.0 & 14.1 & 15.7 & 15.8 & 15.8 \\
\hline Errors and omissions & 15.9 & 10.4 & 8.9 & 0.0 & -11.8 & 0.0 & 0.0 & 0.0 & 0.0 & 0.0 & 0.0 \\
\hline Overall balance & 4.0 & 14.3 & -2.6 & -5.3 & 9.4 & 0.0 & 3.0 & 3.9 & 4.4 & 4.5 & 4.6 \\
\hline Overall financing & -4.0 & -14.3 & 2.6 & 5.3 & -9.4 & 0.0 & -3.0 & -3.9 & -4.4 & -4.5 & -4.6 \\
\hline Change in ECCB NFA & -7.1 & -16.1 & 5.0 & 2.1 & -13.8 & 1.1 & -0.1 & 0.2 & -1.5 & -2.9 & -2.3 \\
\hline Change in net imputed reserves & -7.1 & -16.1 & 5.0 & 2.1 & -25.1 & 1.1 & -0.1 & 0.2 & -1.5 & -2.9 & -2.3 \\
\hline Of which: due to SDR allocatio & & & & & -11.3 & & & & & & \\
\hline Change in medium- and long-term liabilities & & & & & 11.3 & & & & & & \\
\hline \multirow[t]{2}{*}{ IMF reserve liabilities } & 3.2 & 1.8 & -2.5 & 3.2 & 4.4 & -1.1 & -2.9 & -4.0 & -2.8 & -1.6 & -2.3 \\
\hline & \multicolumn{11}{|c|}{ (In percent of GDP) } \\
\hline Current account balance & -26.0 & -15.7 & -25.0 & -31.8 & -28.1 & -25.4 & -23.3 & -23.0 & -22.8 & -21.4 & -20.6 \\
\hline Current account balance including & & & & & & & & & & & \\
\hline net capital transfers & -19.9 & -6.9 & -15.8 & -16.7 & -13.3 & -14.0 & -12.1 & -12.5 & -12.4 & -11.0 & -10.2 \\
\hline Of which: Tourism receipts & 19.1 & 22.6 & 21.8 & 19.6 & 16.6 & 16.9 & 18.4 & 18.7 & 18.9 & 19.1 & 19.3 \\
\hline Capital and financial account & 22.0 & 16.9 & 21.7 & 30.3 & 34.0 & 25.4 & 24.0 & 24.0 & 23.8 & 22.4 & 21.6 \\
\hline Of which: Direct investment & 6.4 & 8.2 & 15.6 & 16.4 & 8.0 & 9.1 & 9.9 & 10.8 & 11.7 & 12.0 & 12.0 \\
\hline \multirow[t]{2}{*}{ External public debt } & 68.8 & 67.7 & 63.6 & 58.9 & 60.1 & 59.8 & 59.3 & 57.6 & 54.1 & 49.3 & 44.7 \\
\hline & \multicolumn{11}{|c|}{ (In percent of exports of goods and nonfactor services) } \\
\hline blic debt service & 12.3 & 11.2 & 10.6 & 10.3 & 12.9 & 15.3 & 15.1 & 14.2 & 13.6 & 14.3 & 14.3 \\
\hline Amortization & 8.9 & 7.5 & 7.2 & 7.1 & 8.4 & 9.8 & 10.3 & 10.4 & 10.0 & 11.0 & 11.3 \\
\hline Interest & 3.4 & 3.6 & 3.4 & 3.3 & 4.5 & 5.5 & 4.7 & 3.7 & 3.5 & 3.3 & 3.0 \\
\hline
\end{tabular}

Sources: Dominican authorities; Eastern Caribbean Central Bank (ECCB); and Fund staff estimates and projections.

$1 /$ Includes stores and bunkers. 
Table 5. Dominica: Summary Accounts of the Banking System

\begin{tabular}{|c|c|c|c|c|c|c|}
\hline & 2005 & 2006 & 2007 & 2008 & 2009 & $\begin{array}{l}\text { Proj. } \\
2010\end{array}$ \\
\hline \multicolumn{7}{|c|}{ (In millions of Eastern Caribbean dollars, end of period) } \\
\hline \multicolumn{7}{|c|}{ Consolidated Banking System } \\
\hline Net foreign assets & 318.0 & 427.2 & 471.2 & 504.1 & 557.3 & 586.5 \\
\hline Net domestic assets & 382.4 & 342.5 & 373.4 & 376.9 & 412.0 & 436.8 \\
\hline $\begin{array}{l}\text { Net credit to the nonfinancial public sector } \\
\text { Of which }\end{array}$ & 15.8 & -46.0 & -70.4 & -73.3 & -87.5 & -115.3 \\
\hline Central government & 67.3 & 12.0 & 2.9 & 10.6 & 4.9 & -18.9 \\
\hline Credit to the private sector & 485.7 & 538.8 & 565.0 & 611.9 & 654.3 & 706.9 \\
\hline Other items (net) $1 /$ & -120.7 & -150.9 & -122.3 & -162.7 & -156.1 & -156.1 \\
\hline Broad money $2 /$ & 700.4 & 769.7 & 844.5 & 881.1 & 969.3 & $1,023.3$ \\
\hline \multicolumn{7}{|c|}{ Monetary Authorities } \\
\hline Imputed net international reserves & 132.7 & 170.2 & 163.2 & 148.8 & 174.1 & 174.0 \\
\hline Net domestic assets & 20.8 & 9.1 & 20.0 & 11.9 & 11.5 & 8.5 \\
\hline Monetary base & 122.3 & 146.9 & 156.1 & 132.8 & 150.2 & 147.2 \\
\hline Currency in circulation & 39.0 & 45.4 & 49.0 & 43.9 & 50.7 & 52.4 \\
\hline Commercial bank reserves & 83.4 & 101.4 & 107.0 & 88.9 & 99.5 & 94.7 \\
\hline \multicolumn{7}{|c|}{ Commercial Banks } \\
\hline Net foreign assets & 185.3 & 257.1 & 307.9 & 355.4 & 383.3 & 412.4 \\
\hline Net claims on ECCB & 78.4 & 99.6 & 148.7 & 90.8 & 99.0 & 94.7 \\
\hline Net domestic assets & 397.8 & 367.6 & 338.8 & 391.0 & 436.3 & 463.7 \\
\hline Net credit to the nonfinancial public sector & -23.5 & -81.2 & -119.8 & -125.5 & -116.8 & -141.6 \\
\hline Credit to the private sector & 485.7 & 538.8 & 565.0 & 611.9 & 654.3 & 706.4 \\
\hline Other (net) & -64.4 & -90.0 & -106.4 & -95.4 & -101.2 & -101.2 \\
\hline Private sector deposits 2 I & 661.4 & 724.2 & 795.5 & 837.2 & 918.7 & 970.8 \\
\hline \multicolumn{7}{|c|}{ Consolidated Banking System } \\
\hline \multicolumn{7}{|c|}{ (Annual percentage change) } \\
\hline Credit to the private sector & 6.0 & 10.9 & 4.9 & 8.3 & 6.9 & 8.0 \\
\hline Private sector deposits & 3.7 & 9.5 & 9.8 & 5.2 & 9.7 & 5.7 \\
\hline Broad money & 3.7 & 9.9 & 9.7 & 4.3 & 10.0 & 5.6 \\
\hline \multicolumn{7}{|c|}{ (Contributions to liquidity growth) 3/ } \\
\hline Net foreign assets & -5.8 & 15.6 & 5.7 & 3.9 & 6.0 & 3.0 \\
\hline Net domestic assets & 9.5 & -5.7 & 4.0 & 0.4 & 4.0 & 2.6 \\
\hline Net credit to the nonfinancial public sector & -1.1 & -8.8 & -3.2 & -0.3 & -1.6 & -2.9 \\
\hline Credit to the private sector & 4.1 & 7.6 & 3.4 & 5.5 & 4.8 & 5.4 \\
\hline Other items (net) & 5.2 & -4.3 & 3.7 & -4.8 & 0.7 & 0.0 \\
\hline \multicolumn{7}{|l|}{$\begin{array}{l}\text { Memorandum items: } \\
\text { Interest rates 4/ }\end{array}$} \\
\hline Time deposit rate & 4.7 & 5.1 & 5.1 & 4.9 & $\cdots$ & $\cdots$ \\
\hline Weighted average lending rate & 9.9 & 9.2 & 9.2 & 8.9 & $\ldots$ & ... \\
\hline
\end{tabular}

Sources: Eastern Caribbean Central Bank (ECCB); and Fund staff estimates and projections.

$1 /$ Includes interbank float.

2/ Including deposits denominated in U.S. dollars.

3 / Change relative to broad money at the beginning of the period.

4/ Commercial banks; end-of-period rates for local currency, percent per annum. 
Table 6. Dominica: Vulnerability Indicators 2004-09 1/

(In percent of GDP, unless otherwise indicated)

\begin{tabular}{|c|c|c|c|c|c|c|}
\hline & 2004 & 2005 & 2006 & 2007 & 2008 & 2009 \\
\hline \multicolumn{7}{|l|}{ Real sector indicators } \\
\hline Real GDP growth (percent) & 3.0 & 3.3 & 4.8 & 2.5 & 3.2 & -0.3 \\
\hline CPI inflation (period average, in percent) & 2.4 & 1.6 & 2.6 & 3.2 & 6.4 & 0.0 \\
\hline \multicolumn{7}{|l|}{$\begin{array}{l}\text { Financial indicators } \\
\text { Commercial Banks }\end{array}$} \\
\hline Total capital asset ratio of banks & 23.5 & 26.2 & 20.8 & 16.9 & 15.8 & 14.3 \\
\hline Of which: Tier 1 capital & 23.0 & 25.8 & 19.1 & 16.0 & 16.5 & 13.5 \\
\hline Liquid assets/total assets & 45.8 & 43.5 & 43.2 & 45.8 & 40.2 & 38.8 \\
\hline Liquid assets/current liabilities & 54.3 & 52.1 & 50.6 & 52.5 & 46.1 & 46.5 \\
\hline Total loans/total deposits & 57.5 & 58.1 & 57.5 & 54.3 & 58.4 & 60.4 \\
\hline Net liquid assets/total deposits & 51.7 & 47.6 & 44.1 & 48.9 & 40.7 & 39.5 \\
\hline Nonperforming loans/total loans & 22.5 & 22.0 & 9.3 & 8.1 & 7.1 & 5.5 \\
\hline Indigenous banks & 41.6 & 32.3 & 5.9 & 5.0 & 4.1 & 5.6 \\
\hline Foreign banks & 13.4 & 15.8 & 11.6 & 10.1 & 9.4 & 5.3 \\
\hline Provisions for loan losses/nonperforming assets & 32.2 & 26.8 & 26.1 & 29.4 & 21.2 & 20.6 \\
\hline Indigenous banks & 40.4 & 33.9 & 7.0 & 3.8 & 7.8 & 5.7 \\
\hline Foreign banks & 20.1 & 18.0 & 32.8 & 38.0 & 25.9 & 36.5 \\
\hline Gross government claims/total assets & 11.4 & 10.4 & 10.1 & 9.4 & 11.7 & 10.8 \\
\hline FX deposits/total deposits & 5.1 & 2.9 & 3.5 & 2.5 & 2.6 & 1.7 \\
\hline Net foreign currency exposure/capital (indigenous banks) & 204.7 & 182.5 & 234.8 & 268.2 & 166.1 & 140.1 \\
\hline Contingent liabilities/capital (indigenous banks) & 63.8 & 62.1 & 85.8 & 85.1 & 164.9 & 126.0 \\
\hline Before-tax profits to average assets (percent) & 0.5 & 0.8 & 2.2 & 2.1 & 0.4 & 3.3 \\
\hline Broad money (percent change, 12-month basis) & 4.5 & 3.7 & 9.9 & 9.7 & 4.3 & 10.0 \\
\hline Private sector credit (percentage change, 12-month basis) & 7.3 & 6.0 & 10.9 & 4.9 & 8.3 & 6.9 \\
\hline \multicolumn{7}{|l|}{ Credit Unions } \\
\hline Liquid assets to total assets $2 /$ & $\ldots$ & $\ldots$ & $\ldots$ & $\ldots$ & $\ldots$ & 29.5 \\
\hline NPLs to total loans $2 /$ & $\ldots$ & $\ldots$ & $\ldots$ & $\ldots$ & $\ldots$ & 8.7 \\
\hline Loans to households to total loans $2 /$ & $\ldots$ & $\ldots$ & $\ldots$ & $\ldots$ & $\ldots$ & 95.0 \\
\hline Before-tax profits to average assets (percent) $2 /$ & $\ldots$ & $\ldots$ & $\cdots$ & $\cdots$ & $\ldots$ & 2.4 \\
\hline U.S. treasury bill rate (percent per annum) & 1.4 & 3.2 & 4.7 & 4.4 & 1.5 & 0.2 \\
\hline Treasury bill rate (percent per annum) & 6.4 & 6.4 & 6.4 & 6.4 & 6.4 & 6.4 \\
\hline \multicolumn{7}{|l|}{ External indicators } \\
\hline Exchange rate (per US\$, end of period) & 2.7 & 2.7 & 2.7 & 2.7 & 2.7 & 2.7 \\
\hline REER appreciation (end of period) & -3.2 & -3.4 & -0.6 & -2.0 & -1.5 & 1.9 \\
\hline Exports of goods and nonfactor services (percent change, 12-month basis) & 10.2 & -0.9 & 11.7 & 2.4 & -2.3 & -9.6 \\
\hline Imports of goods and nonfactor services (percent change, 12-month basis) & 10.7 & 12.6 & 1.4 & 19.6 & 14.6 & -11.6 \\
\hline Travel receipts (gross, percent change, 12-month basis) & 15.8 & -5.9 & 25.7 & 3.9 & -3.9 & -15.9 \\
\hline Current account balance (percent of GDP) & -20.4 & -26.0 & -15.7 & -25.0 & -31.8 & -28.1 \\
\hline Capital and financial account balance (percent of GDP) & 8.6 & 22.0 & 16.9 & 21.7 & 30.3 & 30.7 \\
\hline Net FDI inflows (percent of GDP) & 9.2 & 6.4 & 8.2 & 15.6 & 16.4 & 8.0 \\
\hline Gross international reserves (GIR) in the ECCB (in US\$ millions) & 42.3 & 49.1 & 63.0 & 60.4 & 55.1 & 64.5 \\
\hline GIR in months of current year imports of goods and nonfactor services & 2.9 & 3.0 & 3.8 & 3.0 & 2.4 & 3.2 \\
\hline GIR to broad money (percent) & 16.9 & 18.9 & 22.1 & 19.3 & 16.9 & 18.0 \\
\hline Public gross external debt (in US\$ million) & 219.0 & 212.1 & 222.7 & 224.3 & 214.0 & 221.4 \\
\hline Public gross external debt to exports of goods and services (percent) & 167.8 & 164.0 & 154.2 & 151.7 & 148.1 & 169.5 \\
\hline Public gross external interest payments to exports of goods and services (percent) & 6.6 & 3.4 & 3.6 & 3.4 & 3.3 & 4.5 \\
\hline Public gross external amortization to exports of goods and services (percent) & 13.9 & 8.9 & 7.5 & 7.2 & 7.1 & 8.4 \\
\hline Public gross external interest payments to fiscal revenue (percent) & 8.0 & 3.7 & 4.0 & 3.1 & 2.8 & 3.4 \\
\hline Public gross external amortization payments to fiscal revenue (percent) & 16.7 & 9.6 & 8.2 & 6.8 & 6.1 & 6.4 \\
\hline \multicolumn{7}{|l|}{ Public Sector Indicators } \\
\hline Central government overall balance (excluding grants) & -6.5 & -6.1 & -3.9 & -9.1 & -10.7 & -10.4 \\
\hline External public debt & 74.9 & 68.8 & 67.7 & 63.6 & 58.9 & 60.1 \\
\hline
\end{tabular}

Sources: Eastern Caribbean Central Bank (ECCB); and Fund staff estimates and projections.

1/ Based on ECCB's re-definition of indigenous and foreign banks, effective on April, 2009.

2/ For 2009, as of end June. 
Table 7. Dominica: Medium-Term Macroeconomic Framework

\begin{tabular}{|c|c|c|c|c|c|c|c|c|c|c|c|}
\hline & \multirow[b]{2}{*}{2005} & \multirow[b]{2}{*}{2006} & \multirow[b]{2}{*}{2007} & \multirow[b]{2}{*}{2008} & \multirow{2}{*}{$\begin{array}{l}\text { Prel. } \\
2009\end{array}$} & \multicolumn{6}{|c|}{ Proj. } \\
\hline & & & & & & 2010 & 2011 & 2012 & 2013 & 2014 & 2015 \\
\hline & \multicolumn{11}{|c|}{ (Annual percentage change) } \\
\hline \multicolumn{12}{|l|}{ National income and prices } \\
\hline GDP at constant (1990) prices & 3.3 & 4.8 & 2.5 & 3.2 & -0.3 & 1.4 & 2.5 & 3.0 & 3.0 & 3.0 & 3.0 \\
\hline \multirow[t]{2}{*}{ CPI (end of period) } & 2.7 & 1.8 & 6.0 & 2.1 & 3.2 & 1.5 & 1.5 & 1.5 & 1.5 & 1.5 & 1.5 \\
\hline & \multicolumn{11}{|c|}{ (In percent of GDP, unless otherwise specified) } \\
\hline \multicolumn{11}{|l|}{ Savings and investment } & 27.9 \\
\hline Public & 10.9 & 11.0 & 13.4 & 16.0 & 17.3 & 16.8 & 17.0 & 16.8 & 15.1 & 13.9 & 13.8 \\
\hline Central government & 9.1 & 9.8 & 12.3 & 15.0 & 16.3 & 15.7 & 14.9 & 13.7 & 12.0 & 10.9 & 10.7 \\
\hline Other public sector & 1.7 & 1.2 & 1.0 & 1.0 & 1.1 & 1.0 & 2.0 & 3.0 & 3.0 & 3.0 & 3.0 \\
\hline Private & 17.9 & 17.9 & 17.8 & 13.5 & 8.7 & 9.2 & 9.4 & 11.7 & 13.7 & 14.0 & 14.1 \\
\hline Gross national savings $1 /$ & 8.9 & 22.0 & 15.3 & 12.8 & 12.7 & 12.0 & 14.3 & 16.0 & 16.4 & 16.9 & 17.7 \\
\hline Public & 4.3 & 6.2 & 6.9 & 6.1 & 6.3 & 6.6 & 6.0 & 7.3 & 7.2 & 7.2 & 7.0 \\
\hline Central government & 8.7 & 11.8 & 14.9 & 16.4 & 17.0 & 15.5 & 14.0 & 13.4 & 12.5 & 12.0 & 11.9 \\
\hline Other public sector & -4.4 & -5.6 & -8.0 & -10.3 & -10.7 & -8.9 & -8.0 & -6.1 & -5.3 & -4.8 & -4.9 \\
\hline Private & 4.6 & 15.8 & 8.4 & 6.7 & 6.4 & 5.4 & 8.3 & 8.7 & 9.2 & 9.7 & 10.7 \\
\hline Savings-investment balance & -19.9 & -6.9 & -15.8 & -16.7 & -13.3 & -14.0 & -12.1 & -12.5 & -12.4 & -11.0 & -10.2 \\
\hline Public & -6.6 & -4.8 & -6.5 & -9.9 & -11.0 & -10.2 & -11.0 & -9.5 & -7.9 & -6.8 & -6.8 \\
\hline Private & -13.3 & -2.1 & -9.3 & -6.8 & -2.3 & -3.8 & -1.1 & -3.0 & -4.5 & -4.3 & -3.4 \\
\hline \multicolumn{12}{|l|}{ Central government finances $2 /$} \\
\hline Revenue & 32.8 & 33.9 & 34.5 & 34.5 & 36.2 & 36.2 & 36.5 & 36.5 & 36.5 & 36.5 & 36.5 \\
\hline Grants & 7.5 & 7.8 & 11.7 & 11.6 & 11.5 & 8.3 & 7.2 & 6.9 & 5.7 & 5.7 & 5.6 \\
\hline Current expenditure & 29.7 & 27.7 & 29.2 & 29.2 & 30.5 & 30.2 & 29.7 & 30.0 & 30.0 & 30.0 & 30.0 \\
\hline Capital expenditure & 9.7 & 10.6 & 14.8 & 16.1 & 16.4 & 15.6 & 14.7 & 13.4 & 11.2 & 11.1 & 10.9 \\
\hline Primary balance & 6.3 & 5.8 & 4.6 & 3.1 & 3.0 & 1.2 & 1.0 & 1.8 & 2.8 & 2.9 & 3.0 \\
\hline Overall balance (incl. grants) 3/ & 1.2 & 3.6 & 2.2 & 0.9 & 0.8 & -1.2 & -0.6 & -0.1 & 1.0 & 1.1 & 1.2 \\
\hline \multicolumn{12}{|l|}{ Memorandum items: } \\
\hline Nonfinancial public sector debt & 100.4 & 95.7 & 90.9 & 84.9 & 83.8 & 83.1 & 81.2 & 78.2 & 74.3 & 70.4 & 66.7 \\
\hline External & 68.8 & 67.7 & 63.6 & 58.9 & 60.1 & 59.8 & 59.3 & 57.6 & 54.1 & 49.3 & 44.7 \\
\hline Domestic & 31.6 & 28.0 & 27.3 & 26.0 & 23.8 & 23.3 & 21.9 & 20.7 & 20.2 & 21.1 & 22.0 \\
\hline
\end{tabular}

Sources: Dominican authorities; Eastern Caribbean Central Bank (ECCB); and Fund staff estimates and projections.

$1 /$ Calculated using the external current account including net external capital transfers.

2/ Calculated on a fiscal year basis. The figures shown correspond to the fiscal year beginning in July, and using calendar year GDP.

$3 /$ Does not include grants that were received but not spent. 
Figure 1. Dominica: Key Characteristics
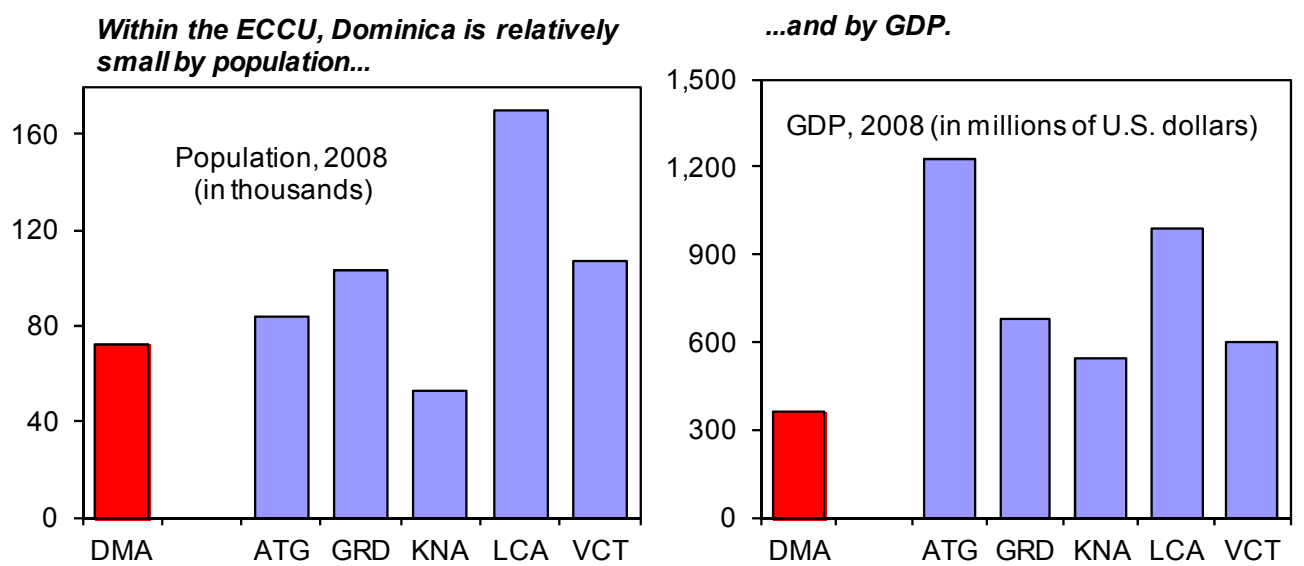

It has a very high emigration rate...

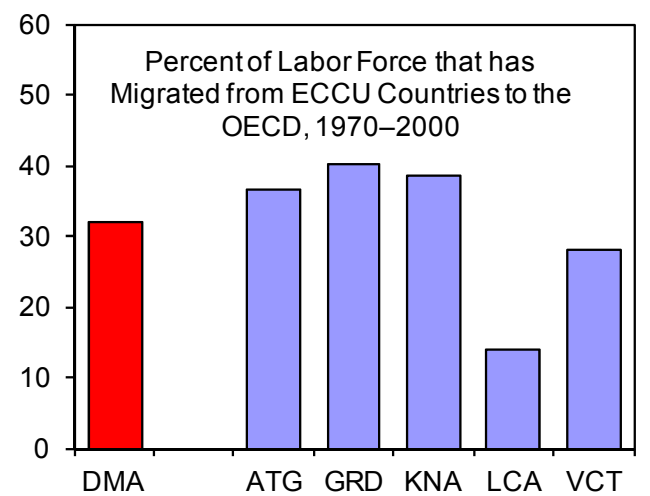

... and a high degree of openness.

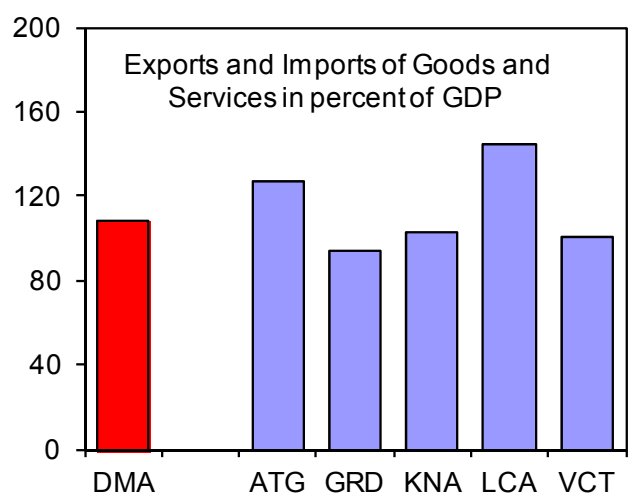

Like other Caribbean countries, Dominica has a high incidence of natural disasters, in terms of population and land area. 1/
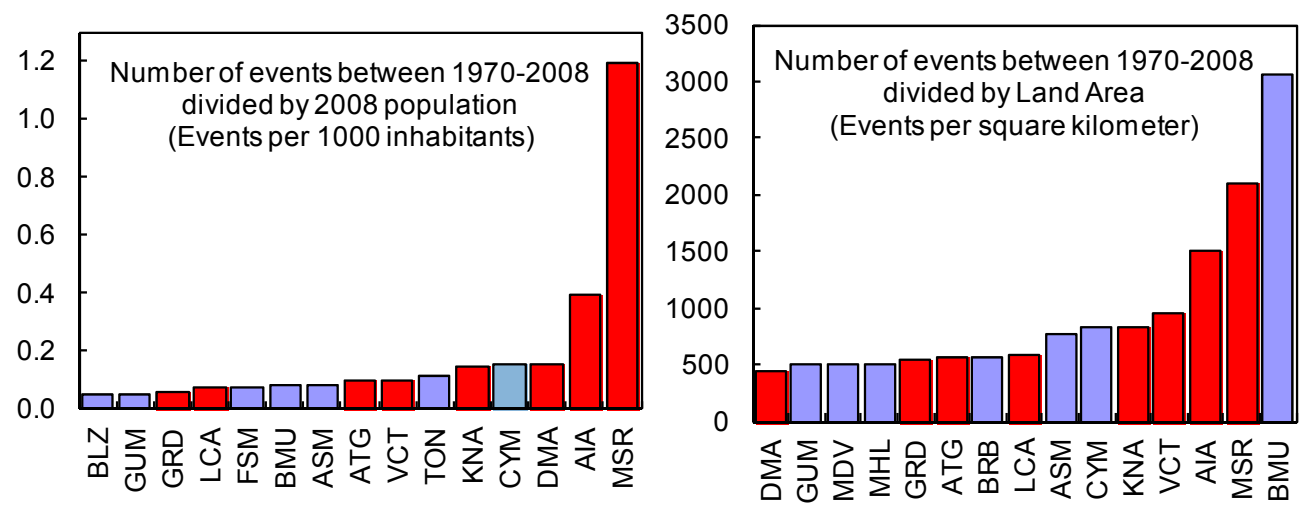

Sources: IMF, WEO; World Bank, WDI; EM-DAT; ECCB; and Fund staff calculations.

$1 /$ Both charts show the 15 countries with the highest number of events in a sample of 190 countries.

Note: American Samoa (ASM), Anguilla (AIA), Antigua and Barbuda (ATG), Barbados (BRB), Belize (BLZ), Bermuda (BMU), Cayman Islands (CYM), Dominica (DMA), Grenada (GRD), Guam (GUM), Maldives (MDV), Marshall Islands (MHL), Micronesia (FSM), Montserrat (MSR), St. Kitts and Nevis (KNA), St. Lucia (LCA), St. Vincent and the Grenadines (VCT), and Tonga (TON). 
Figure 2. Dominica: Growth and External indicators
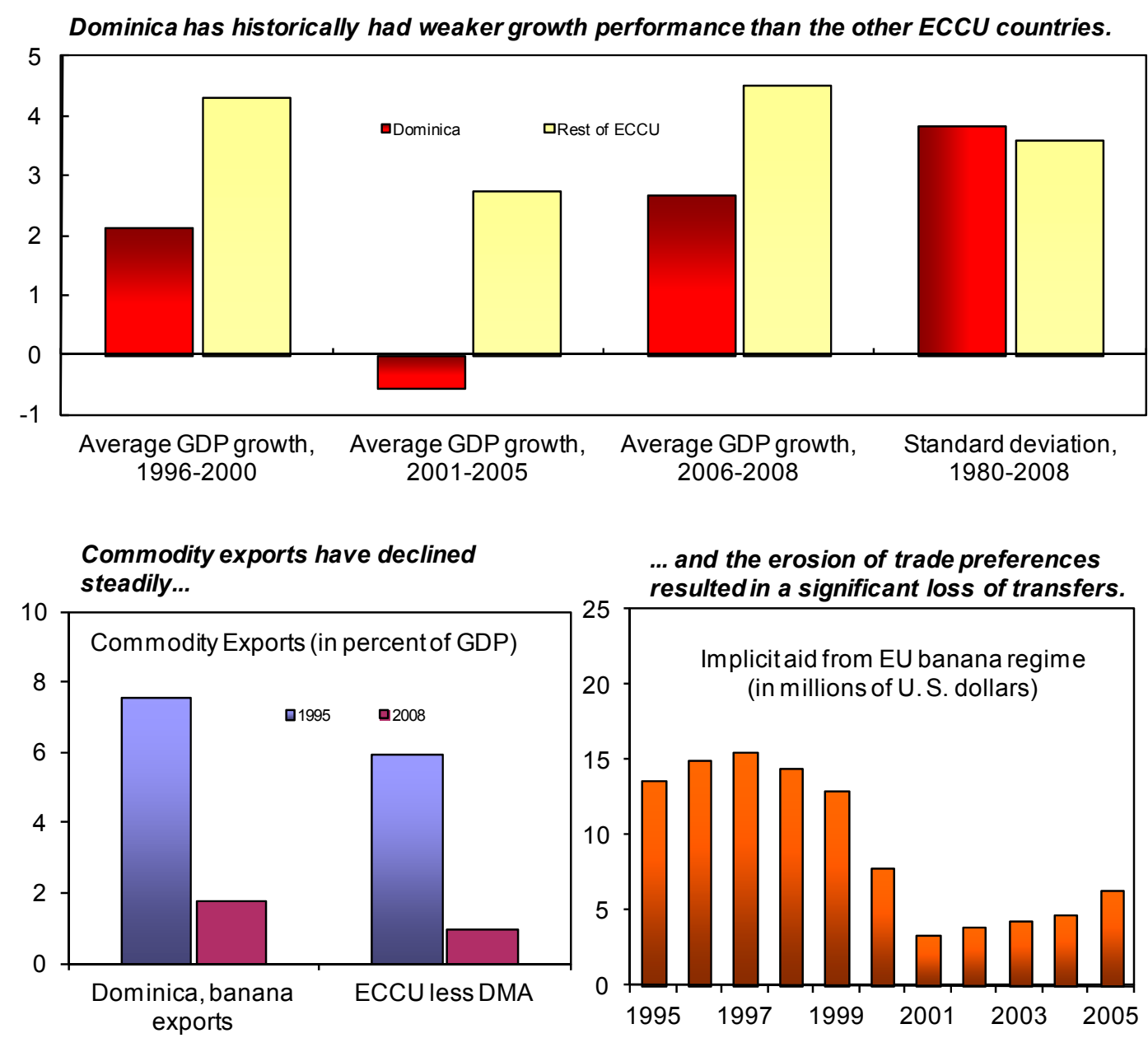

In 2008, grants were by far the highest in the ECCU due to reconstruction efforts ...

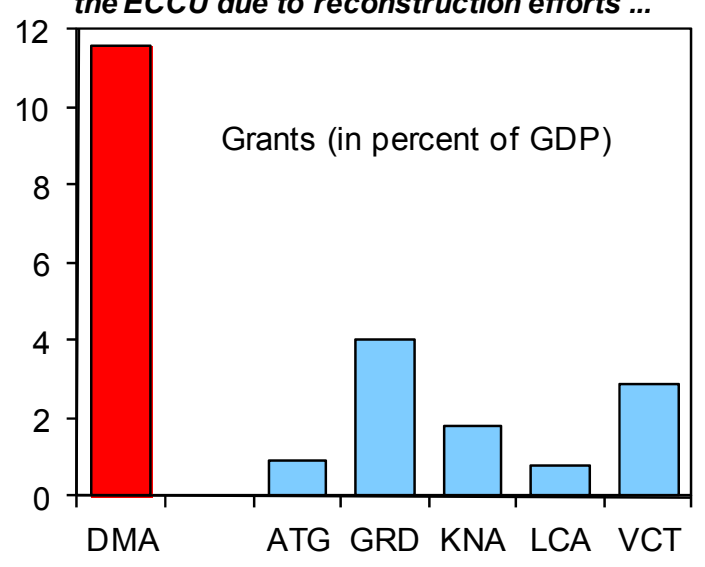

... but FDI was slightly below the average in the rest of ECCU.

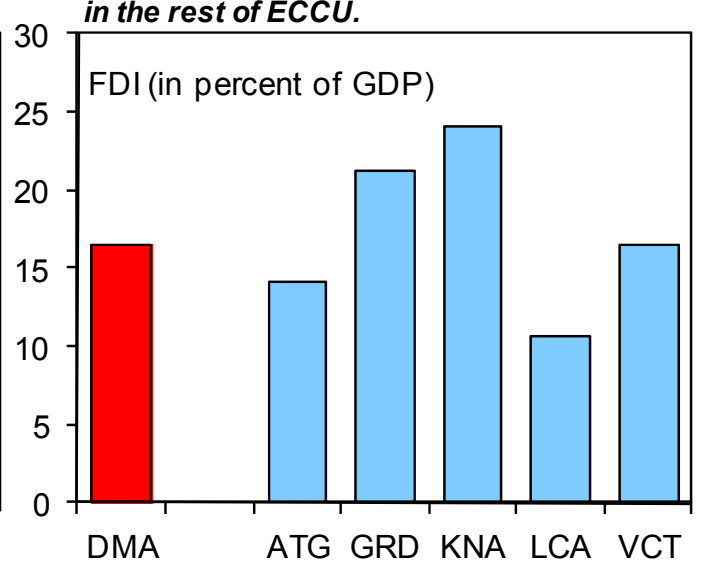

Sources: ECCB; World Bank; and Fund staff estimates. Note: Antigua and Barbuda (ATG), Dominica (DMA), Grenada (GRD), St. Kitts and Nevis (KNA), St. Lucia (LCA), St. Vincent and the Grenadines (VCT). 
Figure 3. Dominica: Governance Indicators, 2008 1/
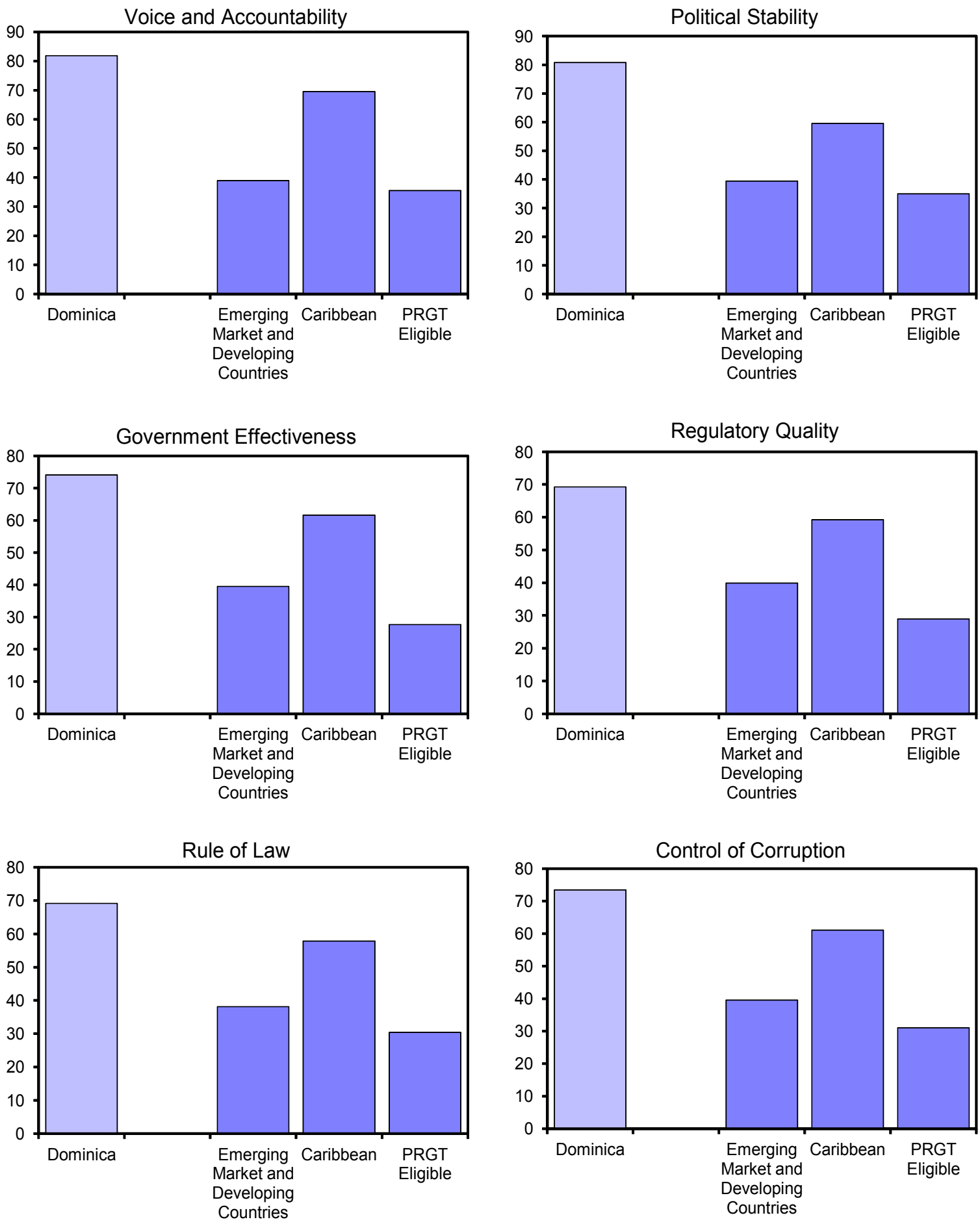

Source: World Bank, World Governance Indicators 2009

1/ Data show the percentile ranking, with higher percentiles representing more favorable rankings. 
Figure 4. Dominica: Selected Indicators

The poverty rate is above 30 percent ...

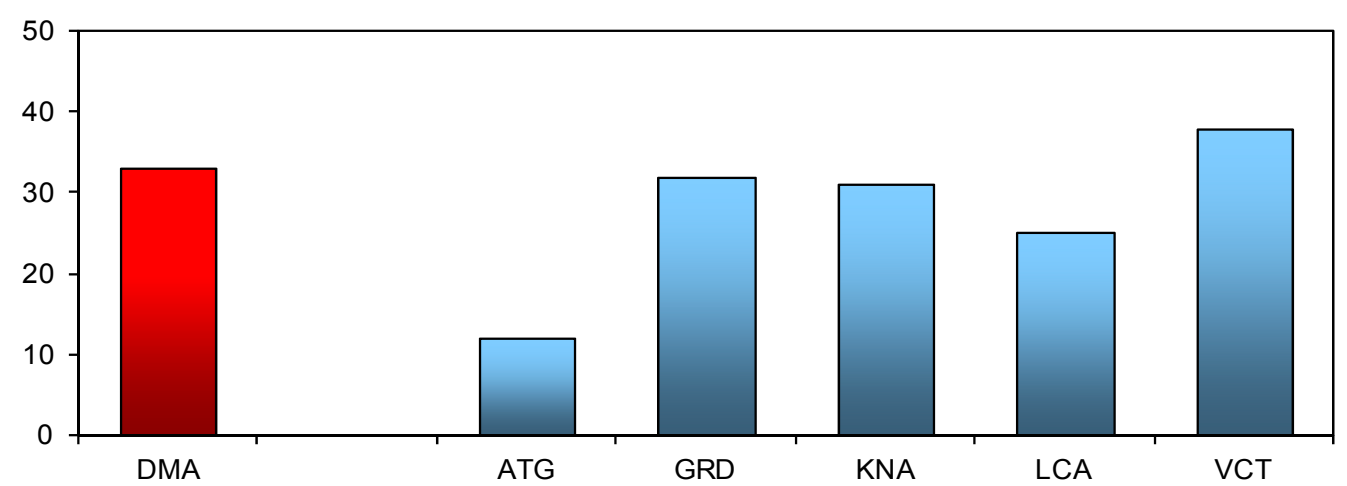

... and inequality is high.

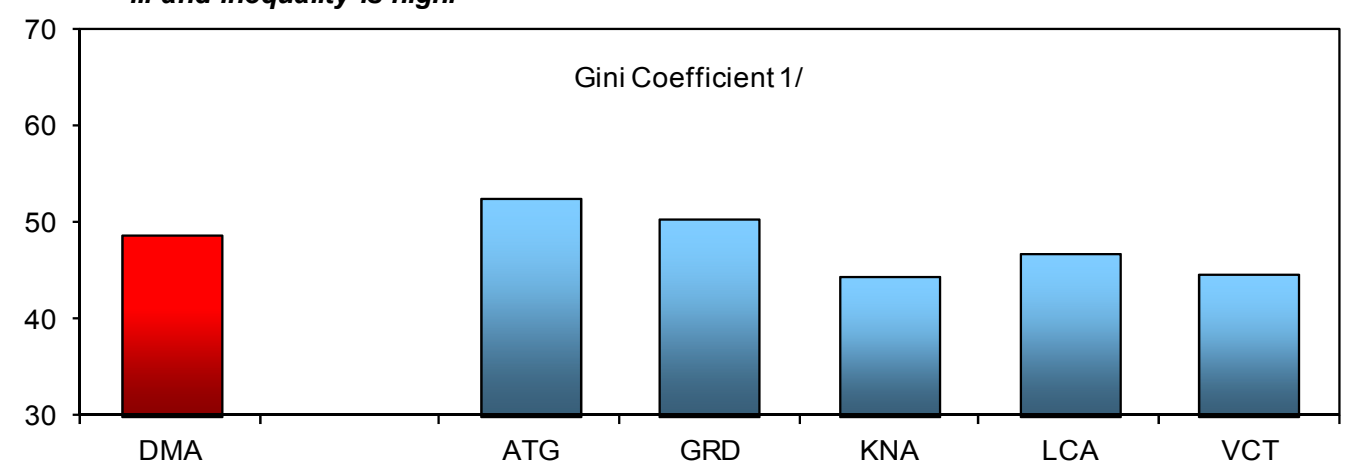

Tourism accounts for a smaller share of Dominica's GDP, while the contribution of agriculture is higher.

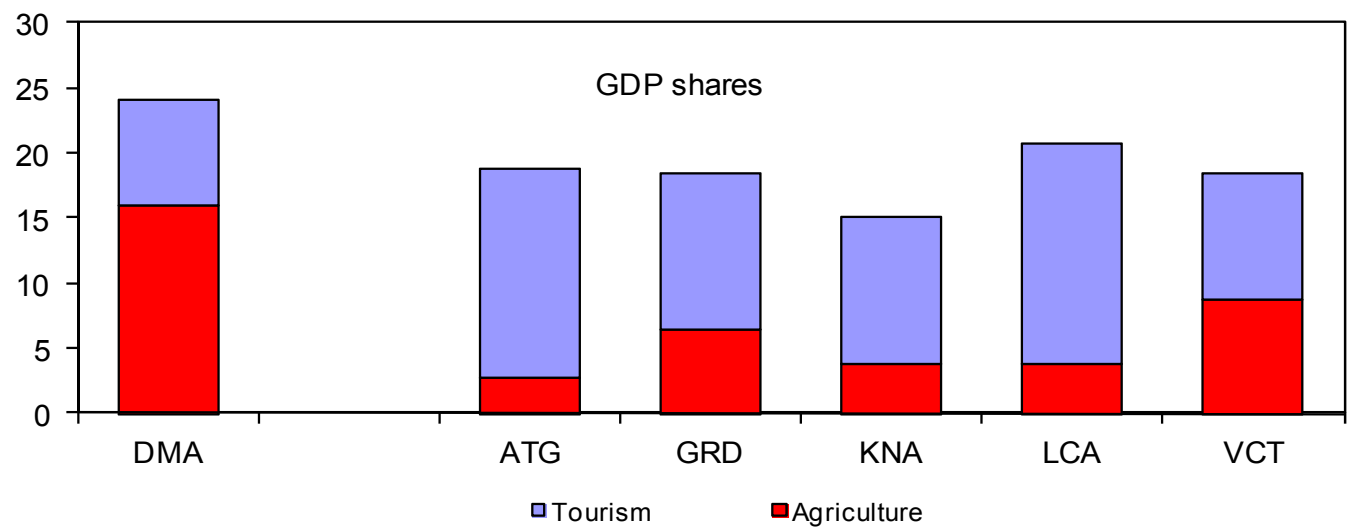

Sources: ECCB; World Bank; and Fund staff estimates.

1/ A larger value indicates greater income inequality.

Note: Antigua and Barbuda (ATG), Dominica (DMA), Grenada (GRD), St. Kitts and Nevis (KNA), St. Lucia (LCA), St. Vincent and the Grenadines (VCT). 
Figure 5. Dominica: Selected Economic Indicators

Fiscal consolidation and structural reforms after the 2001-02 financial crisis have led to strong GDP growth until recently.

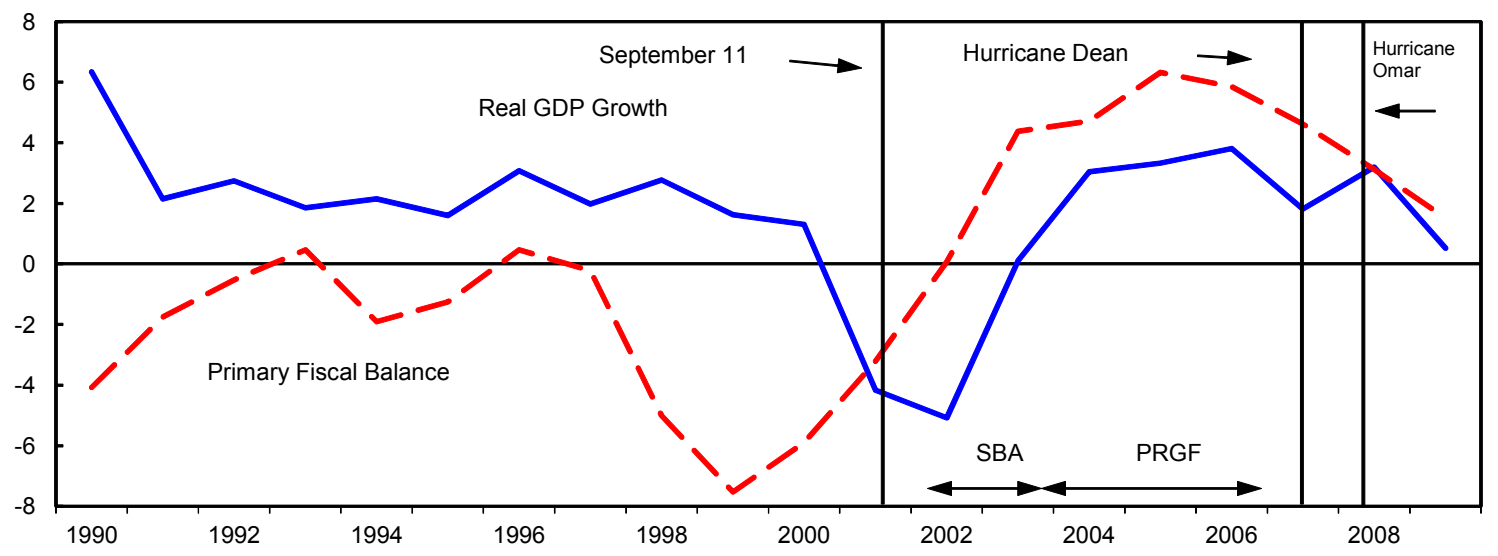

Growth in Dominica has been supported by construction, tourism, and agricultural activity...

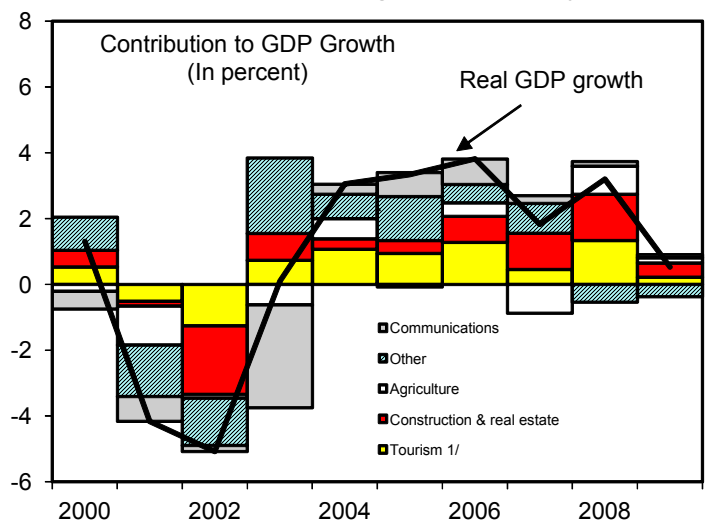

... but has been generally lower than in other ECCU economies.

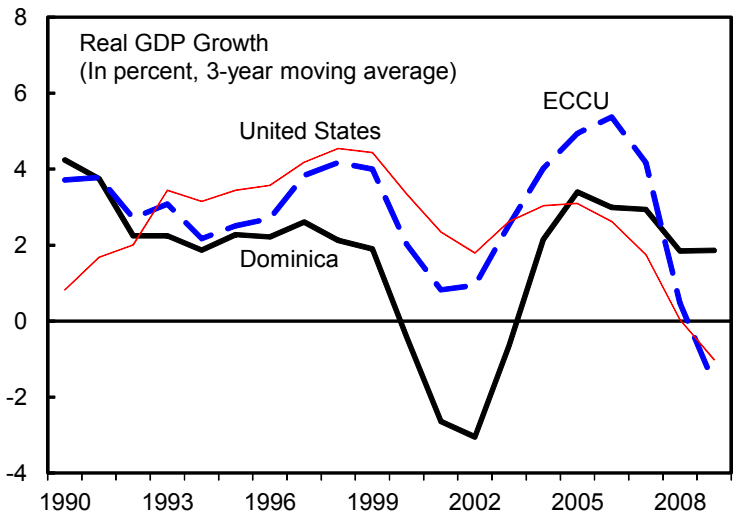

Consumer prices have fallen in line with world fuel and

The debt to-GDP-ratio has declined following the 2004 debt restructuring as a result of prudent fiscal policy.
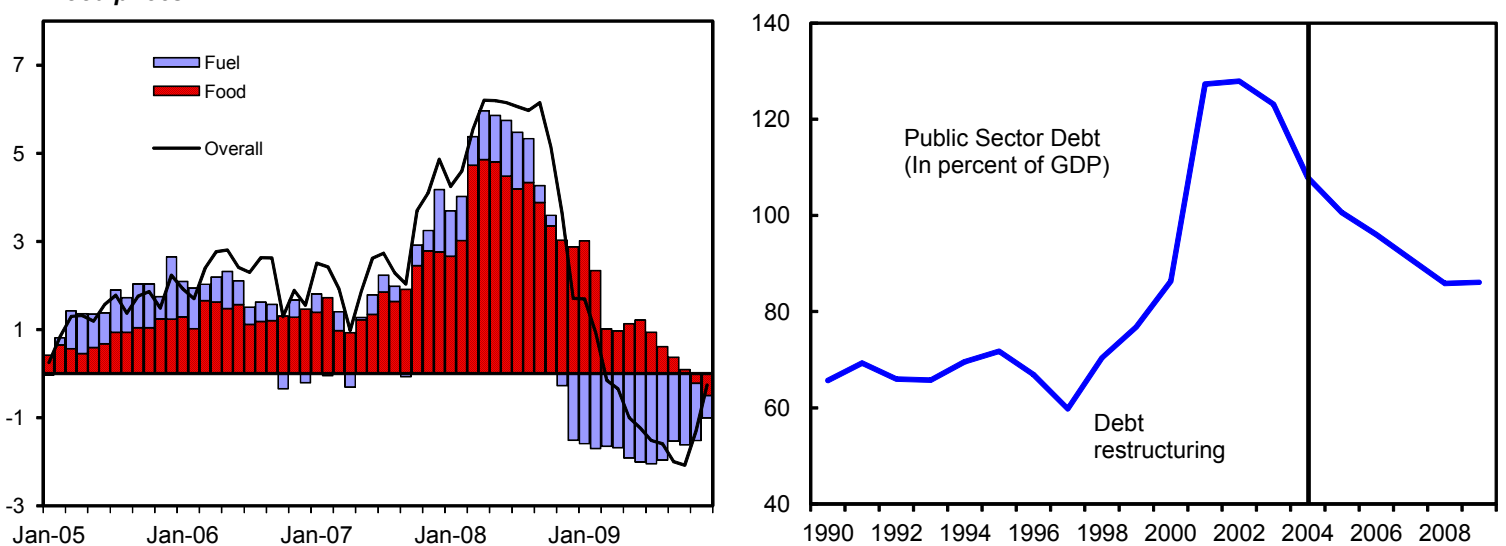

Source: Dominican authorities; ECCB; IMF, International Financial Statistics; IMF, Information Notice System; and Fund staff estimates.

1/ Includes wholesale and retail trade, hotel and restaurant, air transport, and half of local transport. 
Figure 6. Dominica: Fiscal Developments 1/ (In percent of GDP, Central Government)

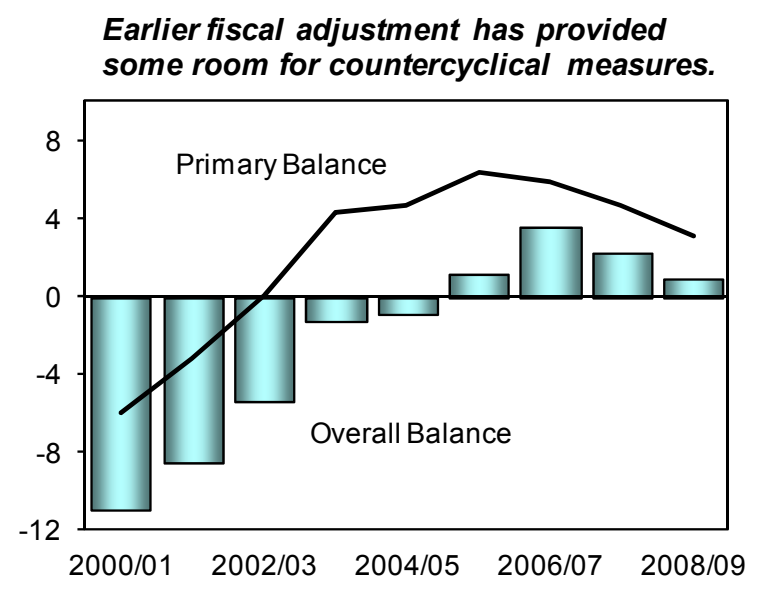

.... while the increase in capital expenditure has been largely financed by grants.

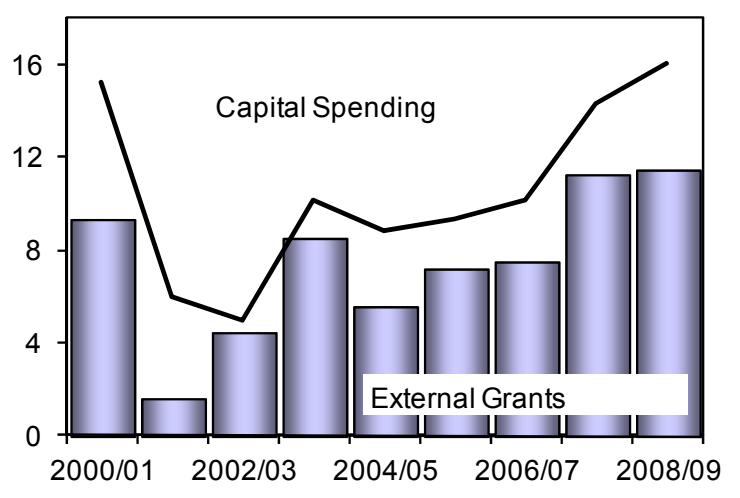

The wage bill has been well contained since 2002, offset by increases in utility costs and some scaling up of social assistance.

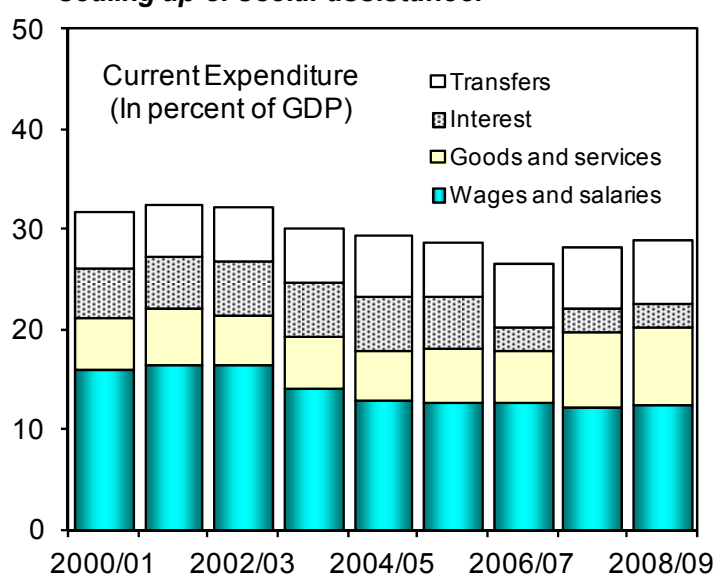

Tax administration has improved markedly, and there is better expenditure control...

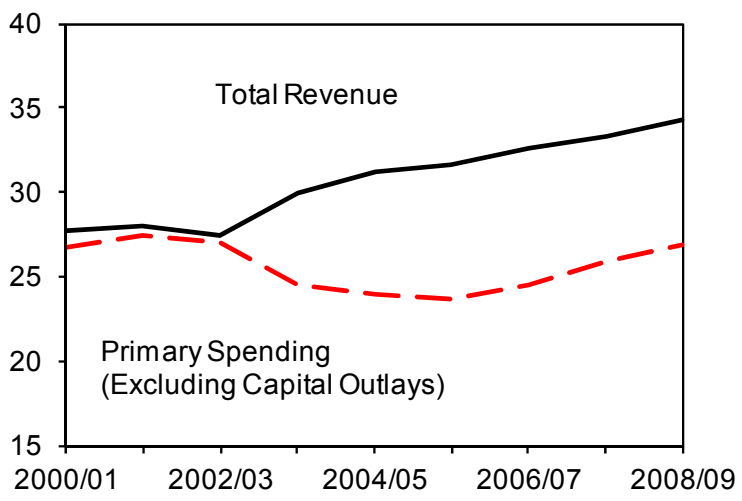

Debt restructuring has reduced the interest burden.

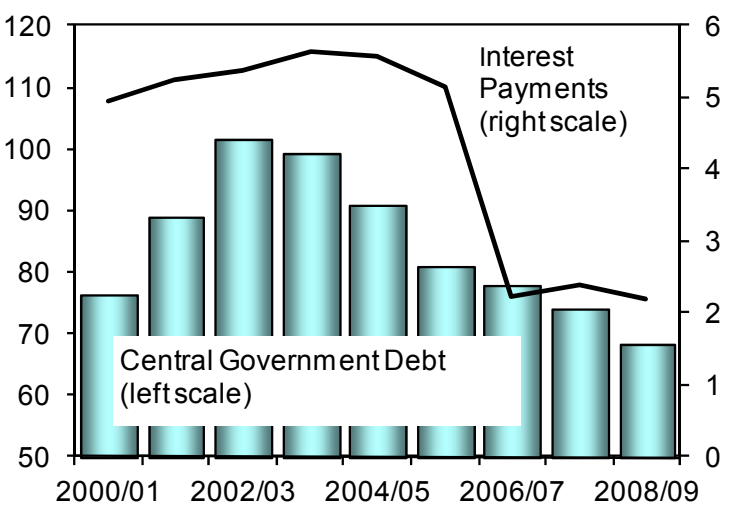

Revenue has been supported by strong performance of the VAT introduced in 2006.

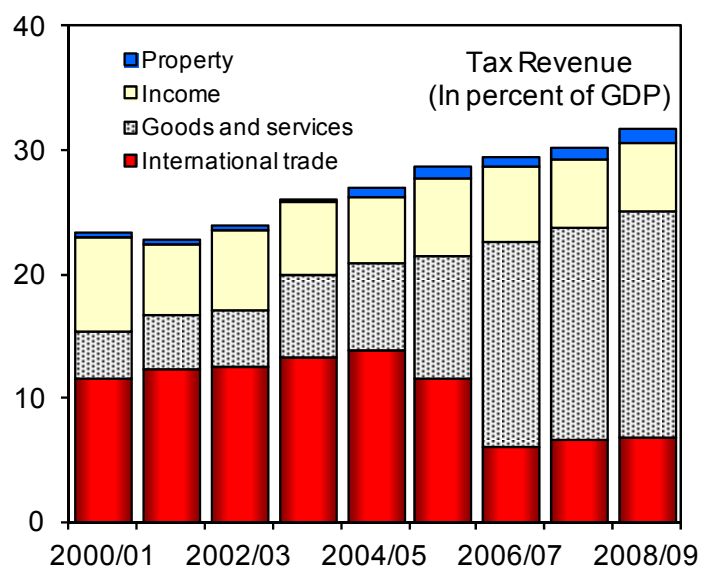

Sources: Dominican authorities; and Fund staff estimates.

1/ Figures shown for a given calendar year relate to the fiscal year (July-June) beginning on July 1 of that year. 
Figure 7. Dominica: Monetary Developments
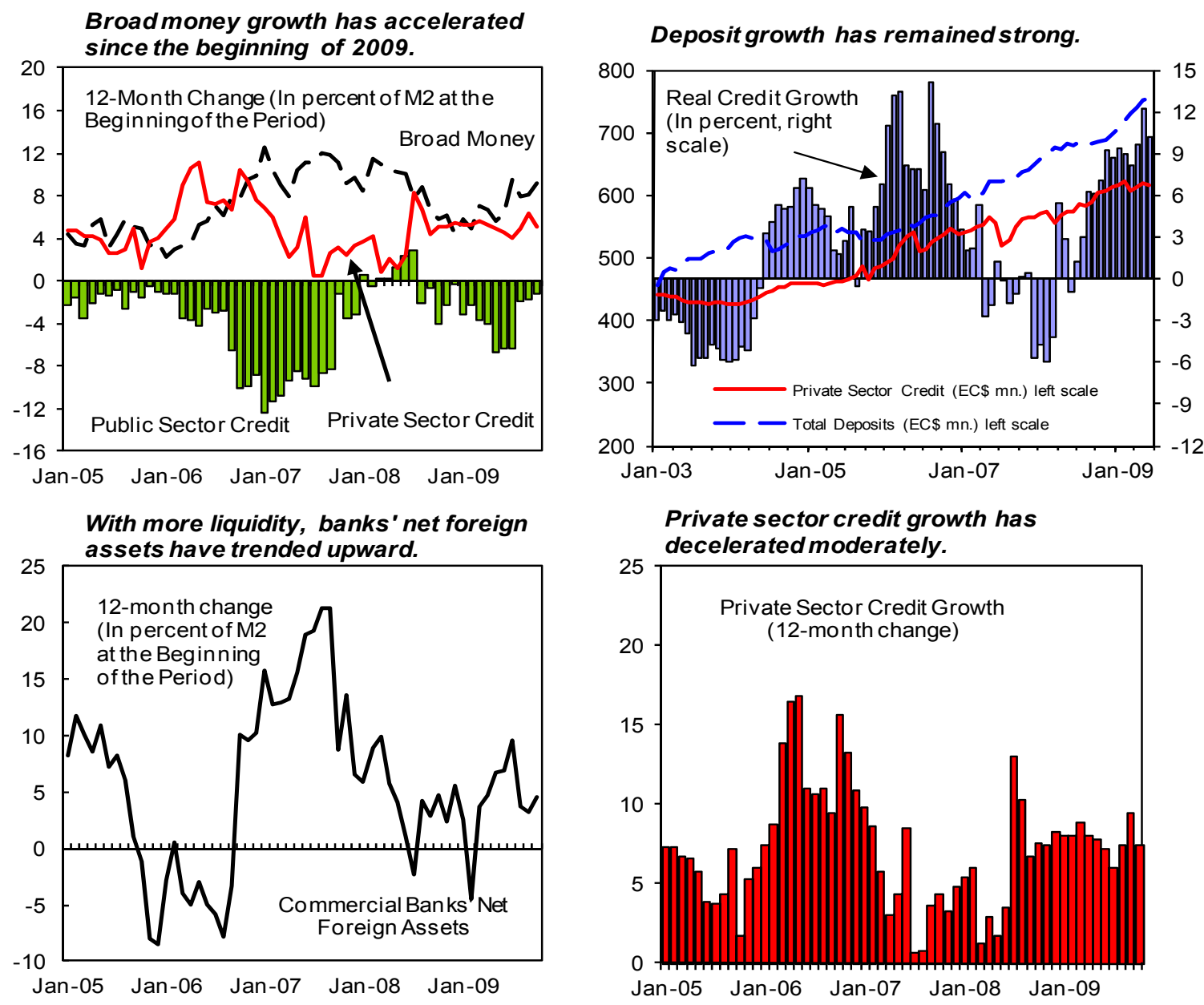

Interest rates have remained stable.

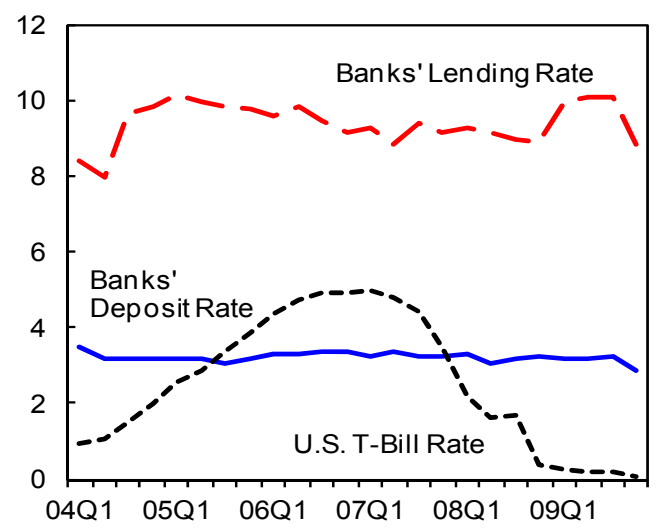

Excess reserves have declined recently.

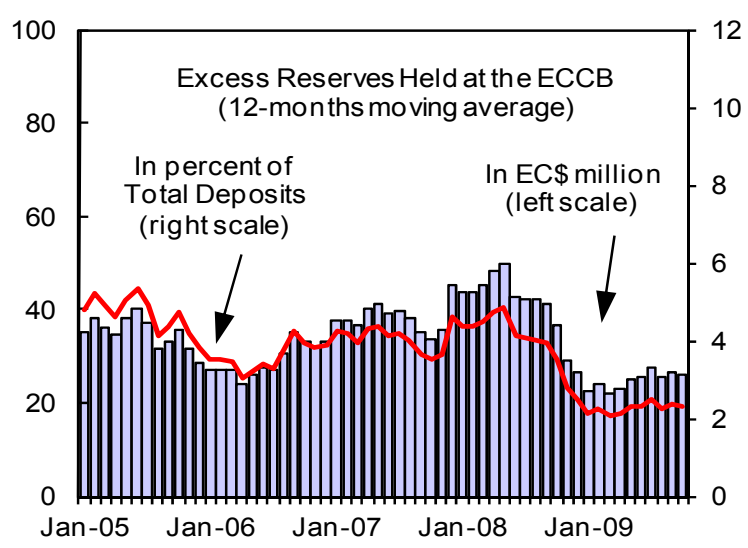

Sources: ECCB; and Fund staff calculations. 
Figure 8. Dominica: Financial Soundness Indicators
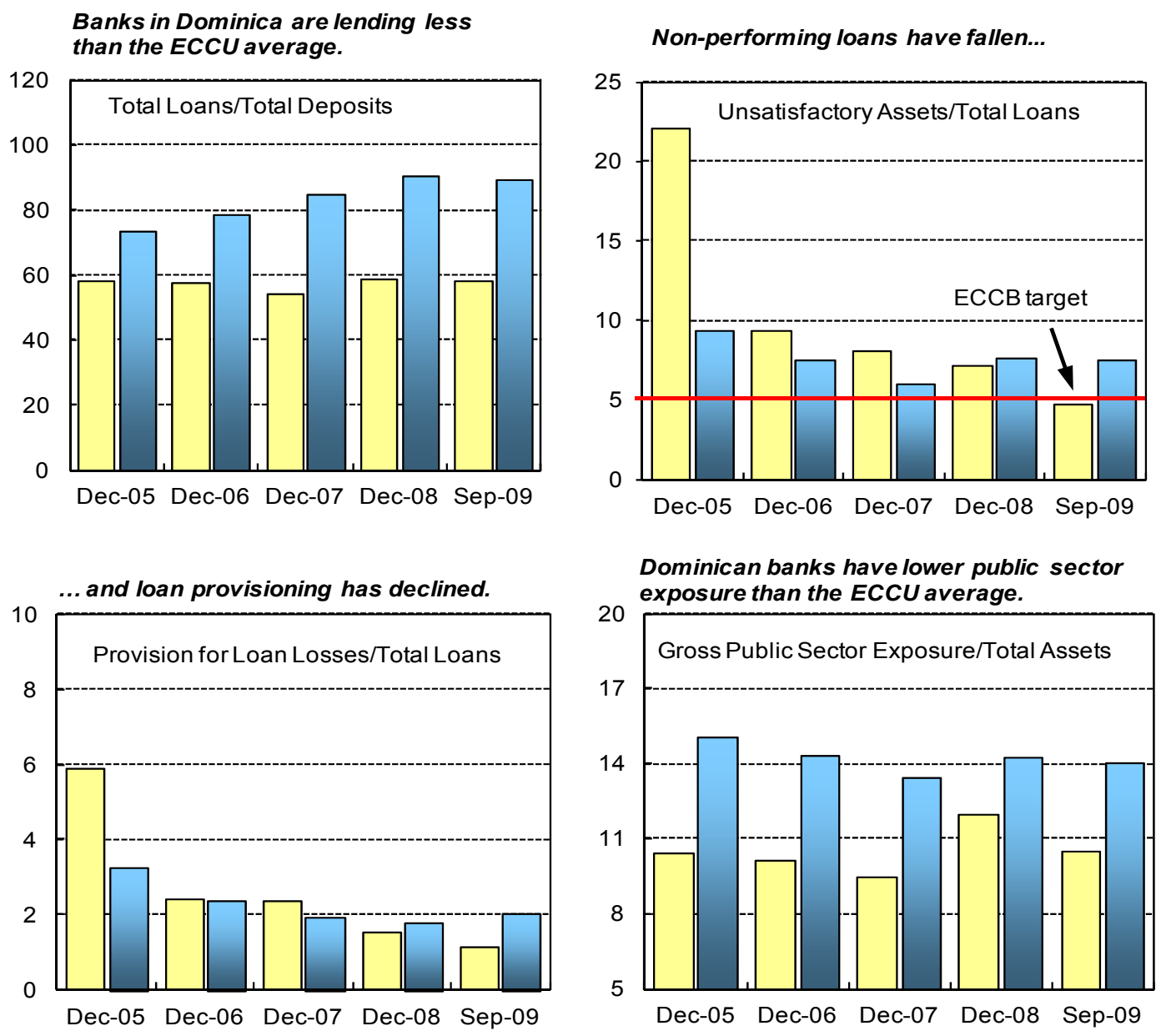

Banks assets are generally more liquid...
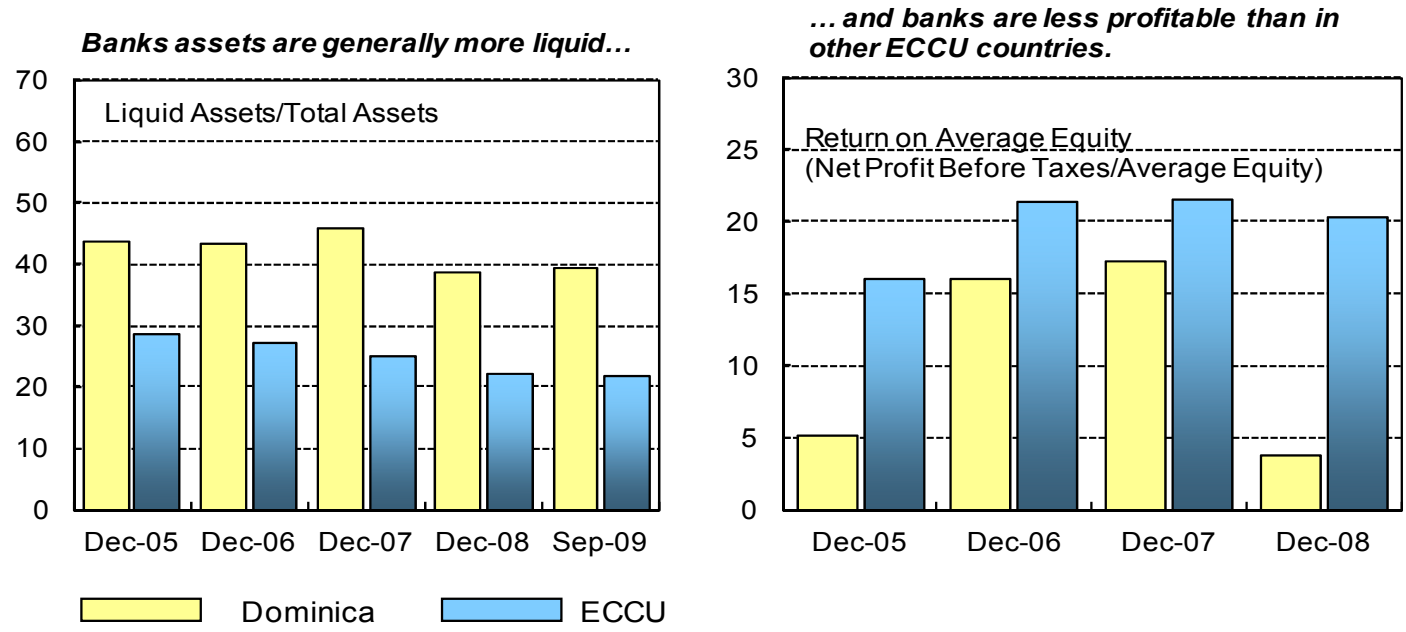

Source: ECCB. 


\section{INTERNATIONAL MONETARY FUND}

\section{DOMINICA}

\section{Debt Sustainability Analysis}

Prepared by the Staff of the International Monetary Fund

In consultation with the World Bank Staff

Approved by Antônio Furtado (WHD) and Michele Shannon (SPR)

April 27, 2010

Dominica's debt outlook has deteriorated slightly since the previous debt sustainability analysis (DSA). In the baseline scenario, Dominica would reach the ECCB's 60 percent debt-to-GDP ratio target in 2017, three years before the target date of 2020. However, $a$ large potential loan to build a tourist resort would delay achieving the target until after 2020. Relative to the thresholds based on Dominica's Country Policy and Institutional Assessment (CPIA) rating of "strong", the threshold on the PV of debt-to-GDP ratio is exceeded during 2010-12. Dominica is considered as having a moderate risk of debt distress. However, some of the simulated shocks and potential additional borrowing plans would lead to breaches of the debt burden thresholds. ${ }^{2}$

\section{Context}

\section{The Dominican authorities have pursued sound macroeconomic and structural} policies in recent years. They successfully implemented a reform agenda supported by a Stand-by Arrangement (2001-03) and a PRGF Arrangement (2004-06). The strong fiscal position has allowed a significant reduction in the debt to GDP ratio and created fiscal space to respond to the 2009 global downturn.

2. Dominica's debt prospects have improved considerably in recent years. The public debt-to-GDP ratio has declined from 130 percent in 2003 to 84 percent in 2009 . The major factors behind this improvement are the cooperative debt restructuring that took place in 2004-05 and the prudent fiscal policy maintained by the authorities since then, supported by the strong performance of the VAT introduced in 2006.

\footnotetext{
${ }^{1}$ See IMF Country Report No. 09/293, Dominica-Request for Disbursement under the Rapid-Access Component of the Exogenous Shocks Facility, June 26, 2009.

${ }^{2}$ For a description of the exercise see Staff Guidance Note on the Application of the Joint Fund-Bank Debt Sustainability Framework for Low-Income Countries (IMF Publication, January 25, 2010 http://www.imf.org/external/pp/longres.aspx?id=4419 )
} 
3. The global economic downturn has resulted in lower inflows related to tourist arrivals, FDI and remittances. However, in contrast to other countries in the Eastern Caribbean Currency Union (ECCU), real GDP has declined only modestly reflecting in part the decision of the government to maintain public capital spending in 2009 at the high post-hurricane level in 2008.

\section{Debt management capacity needs to be strengthened and a medium-term debt} management strategy implemented. At the request of the authorities, an MCM mission visited Dominica during October 2009, and provided technical assistance on debt management. The mission recommended pursuing debt sustainability vigilantly as substantial risks remain around the current downward trajectory of debt ratios. It also recommended strengthening debt management capacity and institutional arrangements, and implementing a medium-term debt management strategy. This strategy should build on the current approach that focuses on minimizing the cost of financing, including concessional debt, and contain a plan for managing financial risk and accessing grant financing. The mission also recommended expanding the investor base cautiously via the Regional Government Securities Market (RGSM).

\section{Dominica is rated as a strong performer according to the World Bank's CPIA} ratings. The CPIA rates countries against a set of 16 criteria grouped in four clusters: (i) economic management; (ii) structural policies; (iii) policies for social inclusion and equity; and (iv) public sector management and institutions. In 2008, Dominica's CPIA three year average, 3.84, implies the country is categorized as a "strong performer".

Debt Burden Thresholds under the Debt Sustainability Framework (Applying to external public debt)

\begin{tabular}{lccccccc}
\hline & \multicolumn{2}{c}{ PV of debt in percent of } & & \multicolumn{2}{c}{$\begin{array}{c}\text { Debt Service in } \\
\text { percent of GDP }\end{array}$} \\
\cline { 2 - 4 } & Exports & GDP & Revenue & & Exports & Revenue \\
\hline Strong policy & 200 & 50 & 300 & & 25 & 35 \\
\hline
\end{tabular}

Source: SM/08/317. Staff Guidance on the Application of the Joint Fund- Bank Debt Sustainability Framework for Low Income Countries.

\section{UNDERLYING ASSUMPTIONS}

6. The baseline scenario is based upon the government's financing needs under current fiscal policies. The main assumptions of the DSA are in Box 1. 
Dominica: Key Assumptions and Indicators in the DSA, 2008-29

(In percent of GDP, unless otherwise indicated)

\begin{tabular}{lrrrrr}
\hline & Prelim. & \multicolumn{4}{c}{ Projections } \\
\cline { 3 - 6 } & 2008 & 2009 & 2019 & 2025 & 2029 \\
\hline Total revenue and grants * & 55.1 & 55.8 & 50.1 & 50.0 & 49.9 \\
Primary (noninterest) expenditure * & 51.8 & 53.3 & 47.2 & 47.0 & 46.7 \\
Primary balance (including grants) * & -3.4 & -2.5 & -2.9 & -3.0 & -3.1 \\
Public debt * & 84.9 & 83.7 & 53.1 & 34.8 & 23.1 \\
External current account & -31.9 & -27.7 & -21.3 & -22.1 & -22.4 \\
Exports of goods and services & 39.8 & 35.5 & 37.5 & 37.1 & 36.9 \\
Real GDP growth (in percent) & 1.4 & 0.5 & 3.0 & 3.0 & 3.0 \\
Inflation rate (average; in percent) & 1.6 & 0.9 & 1.5 & 1.5 & 1.5 \\
\hline
\end{tabular}

Sources: Ministry of Finance; and Fund staff estimates and projections.

* Refer to the fiscal year (July-June) that begins in the year shown.

\section{Box 1. Baseline Macroeconomic Assumptions (2010-29)}

- Real GDP growth in the medium term is projected to reach 3 percent, above the average of 0.9 percent in the past ten years, but below the average of 3.4 percent excluding the crisis years of 2001 and 2002. The projection incorporates the effects of authorities' continued efforts to advance their reform agenda and to foster private-sector led growth. Inflation is expected to remain at about 1.5 percent from 2011 onwards.

- The primary surplus (including grants), which averaged 4.8 percent of GDP in FY2006/07-FY2008/09, is expected to be 3 percent in FY2009/10. The primary surplus is assumed to remain at around 1.3 percent of GDP in FY2010/11-FY2012/13, as a result of the infrastructure spending associated with the loan from China. Afterwards, the level of the primary surplus is assumed to remain at a similar level, around 3 percent of GDP, and the associated overall fiscal deficit is around 1 percent of GDP.

- Grants peaked in FY2008/09 at 11.6 percent of GDP because of post-hurricane reconstruction aid, but a slight decline is expected in FY2009-10. Projected grant financing at around 7.2 percent of GDP over the medium-term implies a decline from recent high levels but would still be higher than the historical average of 6.3 percent during FY2000/01-FY2006/07. This reflects in part recent diversification of trade and economic linkages, especially with China and Venezuela (see SM/08/242, Box 5).

- Concessional lending represents most of the external debt, primarily from the Caribbean Development Bank (CBD) and the International Development Association (IDA). Other sources of concessional lending are China and Venezuela.

- After peaking at 32 percent of GDP in 2008, the external current account deficit is expected to stay at a level close to 23-25 percent of GDP in 2010-12 due to imports related to infrastructure spending, and then stabilize at around 20-21 percent afterwards. Exports are expected to stabilize after an 11 percent reduction in 2009 and a somewhat slow recovery in 2010-14. FDI flows are expected to finance around half of the current account deficit from 2013 onwards. 
7. The current baseline scenario incorporates a US\$40 million concessional loan from the Export-Import Bank China. The loan will finance education and infrastructure projects leading to a reduction of the primary surplus to around 1.3 percent of GDP in the next three fiscal years. It is assumed that the primary balance remains at around 3 percent of GDP thereafter. The medium-term growth impact of the loan is uncertain as most materials would be imported and the investment in education would likely take some time to yield a return.

\section{Evaluation of Public Sector Debt Sustainability}

8. Dominica's public debt has decreased considerably. From a peak at 130 percent of GDP in 2003, the public debt-to-GDP ratio decreased to 84 percent in 2009. External debt accounts for three quarters of total debt. The central government accounts for 94 percent of public debt. Among external creditors, multilateral lending represents 66 percent of the total, followed by lending from commercial banks, 16 percent, and bilateral sources, 15 percent (Table 1).

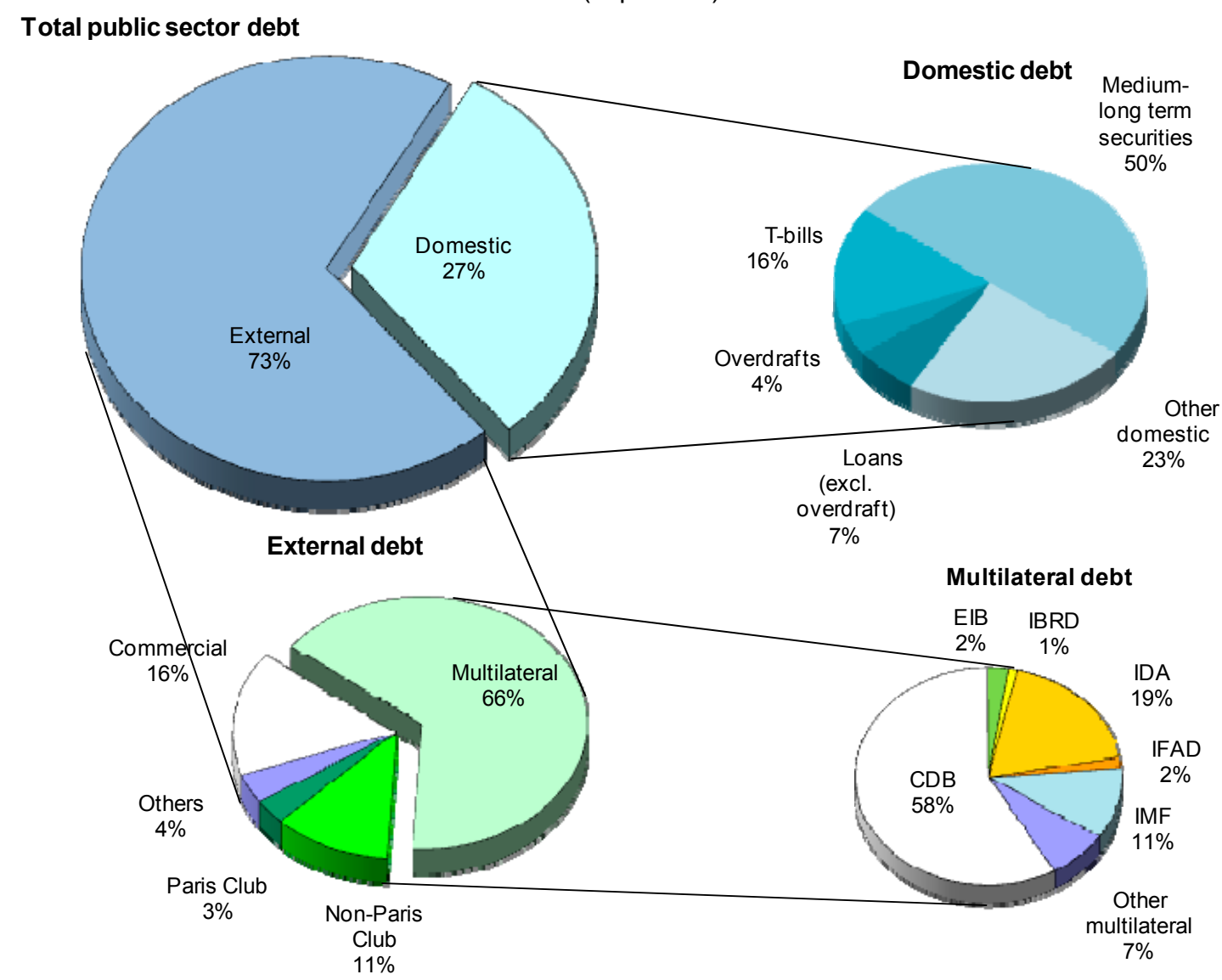

Source: Dominican authorities. 


\section{The baseline scenario}

9. The debt sustainability outlook has deteriorated slightly relative to the last DSA analysis, reflecting in part new borrowing discussed below. In the baseline scenario, Dominica will reach the ECCU target of 60 percent debt-to-GDP ratio by 2017, one year later than in the previous DSA but still three years before the 2020 target date. It is projected that the ratio of NPV of the public debt-to-GDP will fall from 72 percent of GDP in 2008 to 25 percent in 2029. On the other hand, the ratio of the NPV of external debt-to-GDP is expected to fall from 46 percent in 2008 to 19 percent in 2029 (Table 4).

\section{The baseline projection incorporates a US\$40 million loan from China for} projects in education and infrastructure. About US\$24 million (7 percent of GDP) of the total would represent new expenditure and external financing not previously incorporated in the fiscal projections. ${ }^{6}$ This expenditure and the existing financing pipeline from other creditors will imply a weakening in the primary surplus in the period FY2010/11-FY2012/13.

11. The baseline scenario does not include a proposed additional US\$60 million loan from China, equivalent to 16 percent of GDP. This additional borrowing to build a resort project constitutes the main risk to the debt sustainability projections, even when its potential effects could be partially limited by the revenue stream that may be obtained from the project. However, those revenue flows involve a high degree of uncertainty.

\section{This loan would need to generate substantial economic growth to be debt}

neutral. Although the terms of the possible loan are not clear, we assume for the purposes of analysis that the loan will be disbursed during 2010-12, with two percent interest rate, five years grace, and 20 years maturity. In that case, the debt to-GDP ratio in 2012 once the loan is fully disbursed would be 15 percentage points higher than under the baseline. As a result, achieving the same debt-to-GDP ratio in 2020 as in the baseline scenario would require GDP to grow 2.8 percentage points faster each year during 2013-20.

\section{The risks surrounding the baseline debt projections are:}

- Additional borrowing. The proposed US\$60 million loan for the construction of a tourism resort could have an adverse impact on the debt trajectory;

- GDP growth. A slow global recovery and the potential effects of the rebalancing of global demand could lower demand for tourism services; there is a risk of further external shocks; and the growth impact of the reform agenda may be lower than projected;

- $\quad$ Potential contingent liabilities associated with the collapse of the CL Financial Group;

\footnotetext{
${ }^{3}$ The terms of the loans are 2 percent interest, 5 years grace, and 20 years maturity, which imply a grant element of 36 percent.
} 
- Exogenous shocks as commodity price shocks, natural disasters, reductions in grant inflows and volatility in the demand for tourism services could both slow growth and undermine the fiscal position, preventing further debt reduction; and

- Changes in access to concessional lending. The baseline scenario assumes that multilateral borrowing is available on concessional terms, which is in line with the current Caribbean Development Bank lending policies.

\section{Alternative scenarios and bound tests}

14. The debt outlook generally worsens under alternative scenarios. If there is a permanently lower rate of growth or if GDP growth and the primary balance stay at historical averages, trajectories for the debt-to-GDP ratio are higher than in the baseline scenario. On the other hand, if the primary balance remains unchanged at the 2009 level, the trajectory for the debt-to-GDP ratio would be very similar to the one in the baseline (Table 3 ).

\section{A possible additional US\$60 million loan from China would worsen the debt} outlook. The additional loan that may be disbursed in 2010-2012 would imply that the 60 percent target level for the debt-to-GDP ratio would not be reached by 2020 without a strong growth impact. On the other hand, taking into account a considerable positive impact of the resort project on GDP growth, ${ }^{4}$ the 60 percent target level would be reached in $2020 . .^{5}$

16. According to standard bound tests, shocks to GDP growth may have the greatest impact on the debt outlook. More specifically, a reduction of GDP growth by one standard deviation from its historical average during 2010-11 would dramatically worsen the debt projections. In this scenario, the PV of debt-to-GDP ratio would be 70 percent in 2029 compared to 25 percent under the baseline scenario. Among bound tests, this shock also produces the worst results for the PV of debt-to-revenue ratio and the debt service-to-revenue ratio (Table 3).

\section{External DebT Sustainability}

\section{In the baseline scenario, one debt burden threshold would be breached} temporarily. Between 2010 and 2012, the PV of the debt-to-GDP ratio is just below the 50 percent threshold. However, all other ratios-PV of debt to exports and revenue and debt service to exports and revenue-will remain well below their corresponding thresholds (Table 5a)

\footnotetext{
${ }^{4}$ The rate of GDP growth is projected to increase by 0.3 percentage points during the construction period, 2010-2012, and afterwards GDP growth would be boosted by one percentage point for five years.

${ }^{5}$ Historically, the link between public investment and growth in the ECCU has been weak; see Shaun Roache, "Public Investment and Growth in the Eastern Caribbean," IMF Working Paper 07/124.
} 
18. A second loan for US\$60 million would worsen the debt outlook. The PV of debt-to-GDP ratio would be over its threshold of 50 percent between 2010 and 2014 (Figure 2). However, the other four thresholds would not be breached.

19. The risks depicted by the bound tests are concentrated on the PV of debt-toGDP ratio. For most bound tests performed, the PV of debt-to-GDP crosses the 50 percent thresholds. However, all other ratios stay under their corresponding thresholds. In general, standard bound tests show that a combination of shocks to real GDP growth and non debt creating inflows has the largest impact on the external debt outlook (Table 5b).

\section{Conclusion}

20. Dominica's debt ratios have fallen sharply since 2003. The decline reflects the cooperative debt restructuring in 2004-05 and the prudent fiscal policies subsequently maintained by the authorities.

21. The baseline scenario shows a slight deterioration in the debt outlook compared to the previous debt sustainability analysis. This is the result of the global downturn and a new US\$40 million loan. However, the debt-to-GDP ratio will reach the ECCU 60 percent target in 2017, three years before the target date.

22. Large additional borrowing would delay achieving the ECCB target. The main risk associated to the baseline scenario is a potential additional loan for US\$60 million to build a tourist resort. This additional borrowing implies that the ECCU target would not be reached by 2020 . Also, the additional borrowing would imply that Dominica could be considered at moderate risk of debt distress, as one of the five thresholds of the PV of external debt-to-GDP ratio, would be temporarily exceeded in the period 2010-2014. 
Table 1. Dominica: Public Sector Debt, 2008/09

(in millions EC dollars)

\begin{tabular}{|c|c|c|c|}
\hline & & Per & \\
\hline & Stock & Total Debt & GDP \\
\hline Nonfinancial public sector & 833.0 & 100.0 & 84.3 \\
\hline Central government & 783.8 & 94.1 & 79.3 \\
\hline Public enterprises & 49.2 & 5.9 & 5.0 \\
\hline External & 577.9 & 69.4 & 58.5 \\
\hline Central government & 577.9 & 69.4 & 58.5 \\
\hline Multilateral & 378.8 & 45.5 & 38.3 \\
\hline CDB & 220.8 & 26.5 & 22.3 \\
\hline EIB & 9.2 & 1.1 & 0.9 \\
\hline IBRD & 3.9 & 0.5 & 0.4 \\
\hline IDA & 70.9 & 8.5 & 7.2 \\
\hline IFAD & 6.0 & 0.7 & 0.6 \\
\hline IMF & 39.8 & 4.8 & 4.0 \\
\hline Other multilateral & 28.2 & 3.4 & 2.9 \\
\hline Official bilateral & 85.3 & 10.2 & 8.6 \\
\hline Paris Club & 18.6 & 2.2 & 1.9 \\
\hline France & 18.6 & 2.2 & 1.9 \\
\hline Non-Paris Club & 66.8 & 8.0 & 6.8 \\
\hline China & 24.9 & 3.0 & 2.5 \\
\hline Bahamas & 4.1 & 0.5 & 0.4 \\
\hline Barbados & 13.5 & 1.6 & 1.4 \\
\hline Belize & 2.7 & 0.3 & 0.3 \\
\hline Grenada & 2.7 & 0.3 & 0.3 \\
\hline Trinidad and Tobago & 10.0 & 1.2 & 1.0 \\
\hline Kuwait & 8.9 & 1.1 & 0.9 \\
\hline Commercial, total $1 /$ & 91.9 & 11.0 & 9.3 \\
\hline Others & 21.8 & 2.6 & 2.2 \\
\hline Domestic & 255.1 & 30.6 & 25.8 \\
\hline By instruments & & & \\
\hline Loans (excl. overdraft) & 17.0 & 2.0 & 1.7 \\
\hline Overdrafts & 11.3 & 1.4 & 1.1 \\
\hline T-bills & 40.8 & 4.9 & 4.1 \\
\hline Medium-long term securities & 126.5 & 15.2 & 12.8 \\
\hline Other domestic & 59.5 & 7.1 & 6.0 \\
\hline Memorandum items: & & & \\
\hline Central government debt & 205.9 & 24.7 & 20.8 \\
\hline Public enterprise debt & 49.2 & 5.9 & 5.0 \\
\hline Nominal GDP (Fiscal year) & 988.2 & & \\
\hline
\end{tabular}

Sources: Dominica authorities; and Fund staff estimates.

$1 /$ Includes private and monetary authorities.

2/ Includes debt with Dominica Social Security. 
Table 2. Dominica: Public Sector Debt Sustainability Framework, Baseline Scenario, 2006-2029 1/

(In percent of GDP, unless otherwise indicated)

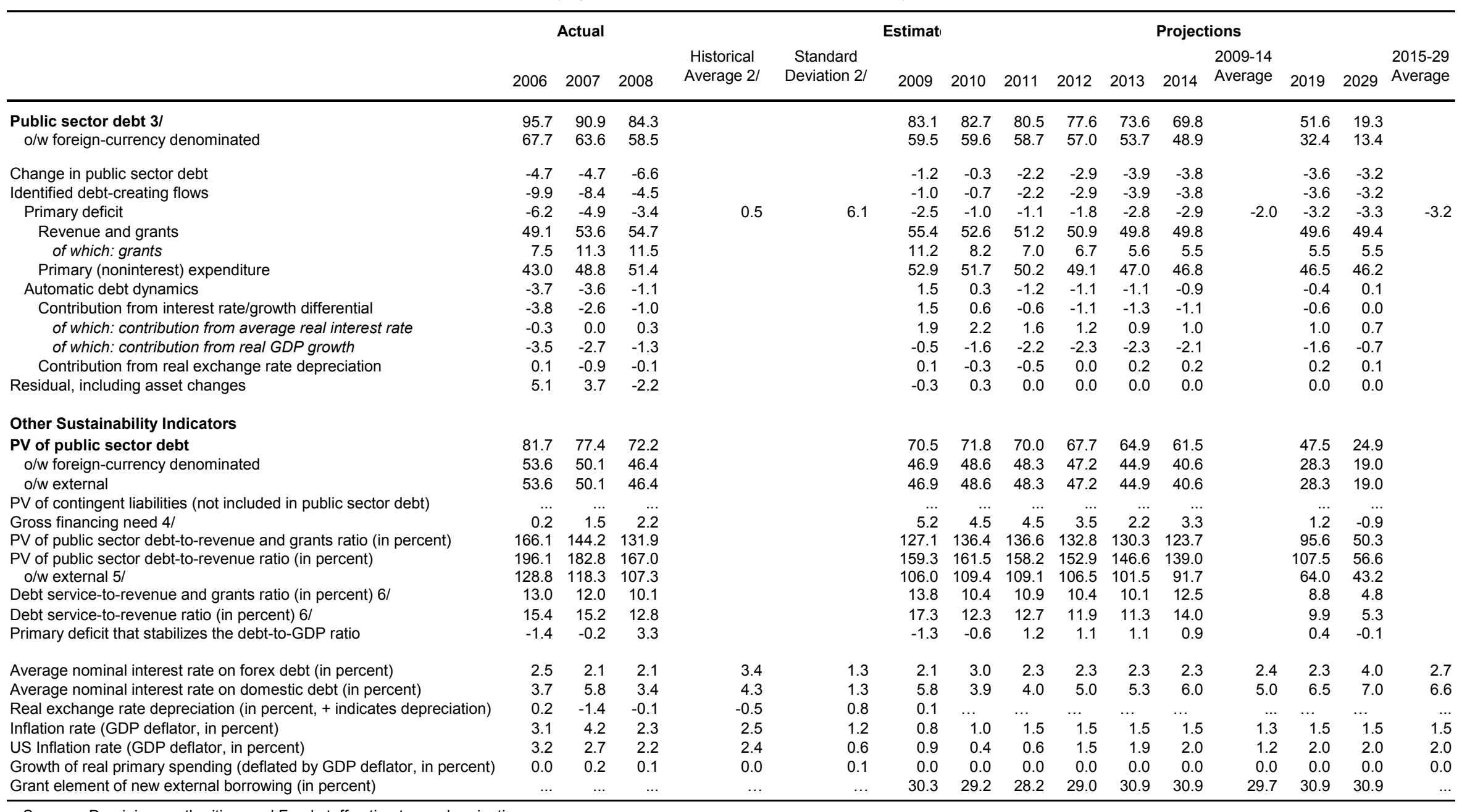

Sources: Dominican authorities; and Fund staff estimates and projections.

$1 /$ Figures shown for a given calendar year relate to the fiscal year beginning on July 1 of that year.

2/ Historical averages and standard deviations are generally derived over the past 10 years, subject to data availability.

3/ Nonfinancial public sector.

4/ Gross financing need is defined as the primary deficit plus debt service plus the stock of short-term debt at the end of the last period

$5 /$ Revenues excluding grants.

6/ Debt service is defined as the sum of interest and amortization of medium and long-term debt. 
Table 3. Dominica: Sensitivity Analysis for Key Indicators of Public Debt 2009-2029

(In percent)

\begin{tabular}{|c|c|c|c|c|c|c|c|c|}
\hline & \multicolumn{8}{|c|}{ Projections } \\
\hline & 2009 & 2010 & 2011 & 2012 & 2013 & 2014 & 2019 & 2029 \\
\hline \multicolumn{9}{|l|}{ PV of Debt-to-GDP Ratio } \\
\hline Baseline & 70.5 & 71.8 & 70.0 & 67.7 & 64.9 & 61.5 & 47.5 & 24.9 \\
\hline \multicolumn{9}{|l|}{ A. Alternative scenarios } \\
\hline A1. Real GDP growth and primary balance are at historical averages & 70.5 & 73.6 & 74.2 & 75.0 & 76.1 & 76.7 & 82.8 & 99.7 \\
\hline A2. Primary balance is unchanged from 2009 & 70.5 & 70.7 & 67.9 & 65.0 & 62.5 & 59.5 & 47.8 & 30.2 \\
\hline A3. Permanently lower GDP growth 1/ & 70.5 & 72.5 & 71.5 & 70.1 & 68.5 & 66.5 & 61.7 & 70.3 \\
\hline A4. Baseline with US\$60 million loan from China & 70.5 & 75.6 & 77.5 & 78.6 & 75.8 & 72.4 & 57.6 & 32.8 \\
\hline A5. Baseline with US $\$ 60$ million loan from China and growth impact & 70.5 & 75.4 & 77.0 & 77.9 & 74.3 & 70.3 & 53.7 & 29.2 \\
\hline \multicolumn{9}{|l|}{ B. Bound tests } \\
\hline B1. Real GDP growth is at historical average minus one standard deviations in $2010-201$ & 70.5 & 75.9 & 80.4 & 80.7 & 80.6 & 79.7 & 78.1 & 76.6 \\
\hline B2. Primary balance is at historical average minus one standard deviations in $2010-2011$ & 70.5 & 77.4 & 81.2 & 78.8 & 76.0 & 72.6 & 57.7 & 32.9 \\
\hline B3. Combination of B1-B2 using one half standard deviation shocks & 70.5 & 76.9 & 80.9 & 80.3 & 79.2 & 77.4 & 71.1 & 61.3 \\
\hline B4. One-time 30 percent real depreciation in 2010 & 70.5 & 92.9 & 90.3 & 87.4 & 84.3 & 80.3 & 64.9 & 42.5 \\
\hline B5. 10 percent of GDP increase in other debt-creating flows in 2010 & 70.5 & 79.1 & 77.3 & 74.9 & 72.1 & 68.8 & 54.1 & 30.0 \\
\hline
\end{tabular}

PV of Debt-to-Revenue Ratio 2I

Baseline

$\begin{array}{llllllll}127.1 & 136.4 & 136.6 & 132.8 & 130.3 & 123.7 & 95.6 & 50.3\end{array}$

\section{A. Alternative scenarios}

A1. Real GDP growth and primary balance are at historical averages

A2. Primary balance is unchanged from 2009

A3. Permanently lower GDP growth 1/

A4. Baseline with US $\$ 60$ million loan from China

A5. Baseline with US\$60 million loan from China and growth impact

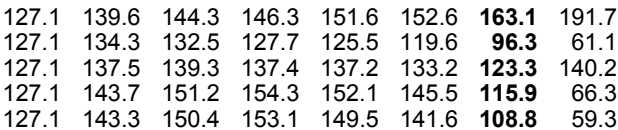

\section{B. Bound tests}

B1. Real GDP growth is at historical average minus one standard deviations in 2010-201 $127.1 \quad 143.4 \quad 155.1 \quad 156.7 \quad 160.1 \quad 158.7 \quad 155.7 \quad 153.4$ B2. Primary balance is at historical average minus one standard deviations in $2010-2011 \quad 127.1 \quad 147.0 \quad 158.4 \quad 154.7 \quad 152.6 \quad 145.9 \quad 116.2 \quad 66.6$

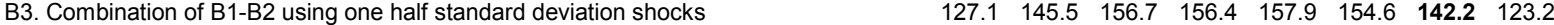

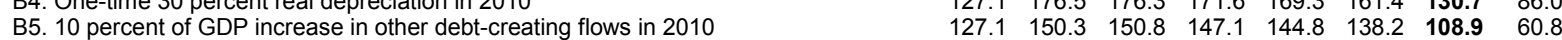

Debt Service-to-Revenue Ratio 2/

Baseline

\section{A. Alternative scenarios}

A1. Real GDP growth and primary balance are at historical averages A2. Primary balance is unchanged from 2009

A3. Permanently lower GDP growth 1/

A4. Baseline with US $\$ 60$ million loan from China

A5. Baseline with US $\$ 60$ million loan from China and growth impact

\section{B. Bound tests}

B1. Real GDP growth is at historical average minus one standard deviations in 2010-201 B2. Primary balance is at historical average minus one standard deviations in 2010-2011 B3. Combination of B1-B2 using one half standard deviation shocks

B4. One-time 30 percent real depreciation in 2010

B5. 10 percent of GDP increase in other debt-creating flows in 2010

Sources: Country authorities; and Fund staff estimates and projections.

$1 /$ Assumes that real GDP growth is at baseline minus one standard deviation divided by the square root of the length of the projection period.

2/ Revenues are defined inclusive of grants.

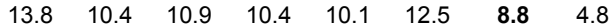

$\begin{array}{rrrrrrrr}13.8 & 10.5 & 11.3 & 10.9 & 10.9 & 13.8 & \mathbf{1 2 . 5} & 15.6 \\ 13.8 & 10.4 & 10.9 & 10.3 & 9.9 & 12.3 & \mathbf{8 . 5} & 5.2 \\ 13.8 & 10.5 & 11.1 & 10.6 & 10.3 & 12.9 & \mathbf{1 0 . 1} & 10.2 \\ 13.8 & 10.4 & 11.1 & 10.7 & 10.6 & 13.0 & \mathbf{1 0 . 8} & 6.8 \\ 13.8 & 10.4 & 11.1 & 10.7 & 10.4 & 12.7 & \mathbf{1 0 . 2} & 6.2\end{array}$

\begin{tabular}{rrrrrrrr}
13.8 & 10.8 & 11.8 & 11.4 & 11.2 & 13.9 & $\mathbf{1 2 . 0}$ & 12.7 \\
13.8 & 10.4 & 11.2 & 10.9 & 10.6 & 13.0 & $\mathbf{1 0 . 8}$ & 6.8 \\
13.8 & 10.6 & 11.7 & 11.2 & 11.0 & 13.6 & $\mathbf{1 1 . 6}$ & 10.7 \\
13.8 & 12.1 & 14.5 & 13.6 & 13.3 & 16.7 & $\mathbf{1 2 . 6}$ & 9.1 \\
13.8 & 10.4 & 11.3 & 10.7 & 10.4 & 12.8 & $\mathbf{1 0 . 1}$ & 6.1 \\
\hline
\end{tabular}


Table 4. Dominica: External Debt Sustainability Framework, Baseline Scenario, 2006-2029 1/ (n percent of GDP, unless otherwise indicated)

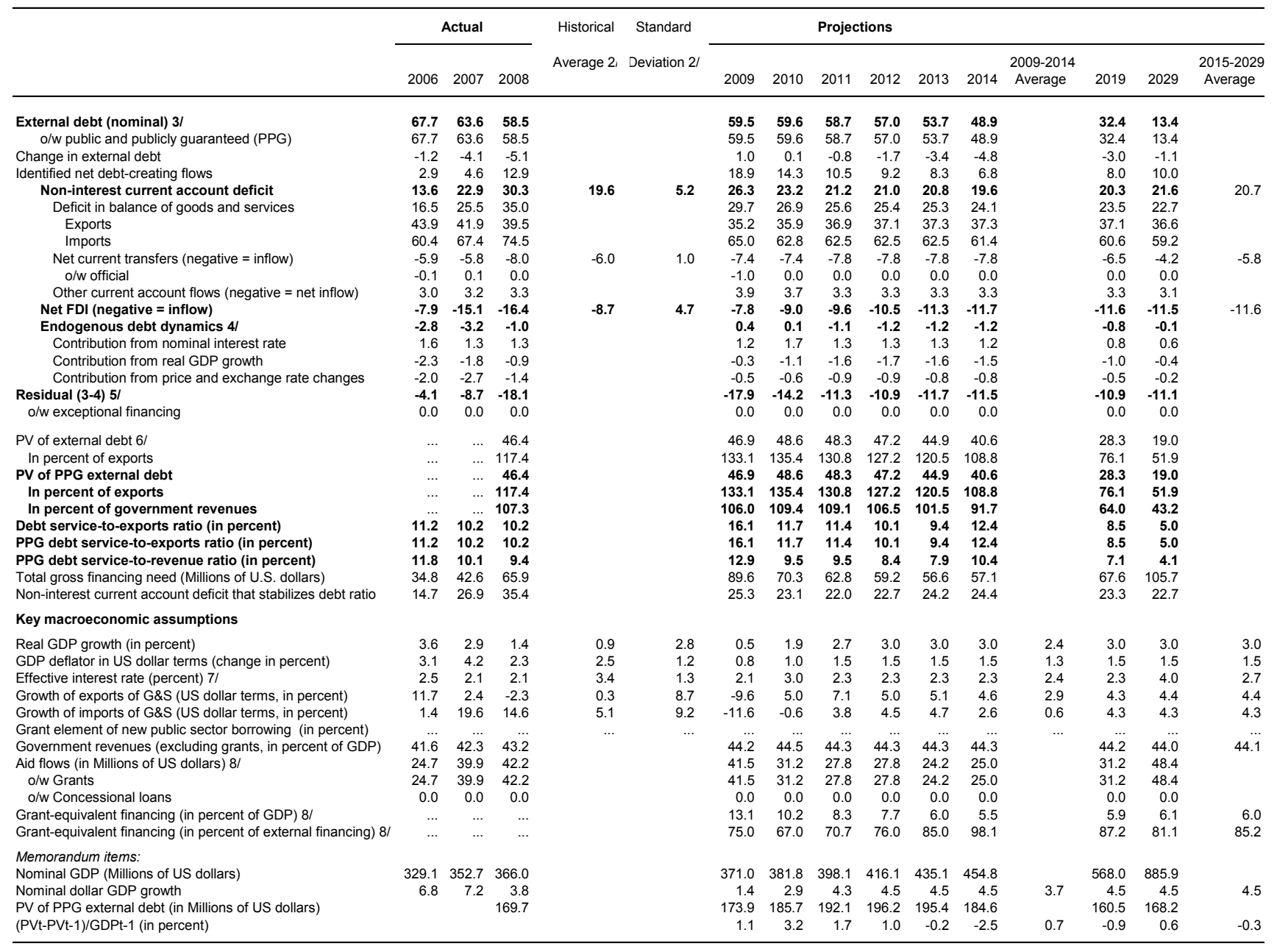

Source: Fund staff simulations.

1/ Figures shown for a given calendar year relate to the fiscal year beginning on July 1 of that year.

2/ Historical averages and standard deviations are generally derived over the past 10 years, subject to data availability.

3/ Only Includes public sector external deb.

Previous period debt ratio, with $r=$ nominal interest rate; $g=$ real GDP growth rate, and $r=$ growth rate of GDP deflator in U.S. dollar terms.

changes in arrears and debt relief); changes in gross foreign assets; and valuation adjustments. For projections also includes contribution from price and exchange rate changes. $7 /$ Current-year interest payments divided by previous period debt stock.

$8 /$ Defined as grants, concessional loans, and debt relief. 
Table 5a. Dominica: Sensitivity Analysis for Key Indicators of Public and Publicly Guaranteed External Debt, 2009-2029 (In percent)

\begin{tabular}{|c|c|c|c|c|c|c|c|c|}
\hline & \multicolumn{8}{|c|}{ Projections } \\
\hline & 2009 & 2010 & 2011 & 2012 & 2013 & 2014 & 2019 & 2029 \\
\hline \multicolumn{9}{|l|}{ PV of debt-to GDP ratio } \\
\hline Baseline & 46.9 & 48.6 & 48.3 & 47.2 & 44.9 & 40.6 & 28.3 & 19.0 \\
\hline \multicolumn{9}{|l|}{ A. Alternative Scenarios } \\
\hline $\begin{array}{l}\text { A1. Key variables at their historical averages in } 2009-20291 / \\
\text { A2. New public sector loans on less favorable terms in } 2009-20292 \\
\text { A3. Baseline with US } \$ 60 \text { million loan from China } \\
\text { A4. Baseline with US } \$ 60 \text { million loan from China and growth impact }\end{array}$ & $\begin{array}{l}46.9 \\
46.9 \\
46.9 \\
46.9\end{array}$ & $\begin{array}{l}45.1 \\
50.2 \\
52.4 \\
52.3\end{array}$ & $\begin{array}{l}44.0 \\
50.9 \\
55.7 \\
55.4\end{array}$ & $\begin{array}{l}43.1 \\
50.5 \\
58.1 \\
57.5\end{array}$ & $\begin{array}{l}41.9 \\
48.6 \\
55.8 \\
54.7\end{array}$ & $\begin{array}{l}39.9 \\
44.3 \\
51.4 \\
49.9\end{array}$ & $\begin{array}{l}37.9 \\
33.1 \\
38.4 \\
35.6\end{array}$ & $\begin{array}{l}37.6 \\
28.8 \\
26.9 \\
23.6\end{array}$ \\
\hline \multicolumn{9}{|l|}{ B. Bound Tests } \\
\hline $\begin{array}{l}\text { B1. Real GDP growth at historical average minus one standard deviation in } 2010-2011 \\
\text { B2. Export value growth at historical average minus one standard deviation in } 2010-20113 / \\
\text { B3. US dollar GDP deflator at historical average minus one standard deviation in } 2010-2011 \\
\text { B4. Net non-debt creating flows at historical average minus one standard deviation in } 2010-20114 / \\
\text { B5. Combination of B1-B4 using one-half standard deviation shocks } \\
\text { B6. One-time } 30 \text { percent nominal depreciation relative to the baseline in } 20105 /\end{array}$ & $\begin{array}{l}46.9 \\
46.9 \\
46.9 \\
46.9 \\
46.9 \\
46.9\end{array}$ & $\begin{array}{l}50.6 \\
52.4 \\
48.5 \\
54.6 \\
55.8 \\
69.2\end{array}$ & $\begin{array}{l}52.5 \\
59.6 \\
48.3 \\
61.1 \\
67.9 \\
68.7\end{array}$ & $\begin{array}{l}51.3 \\
58.5 \\
47.2 \\
59.9 \\
66.7 \\
67.1\end{array}$ & $\begin{array}{l}48.9 \\
56.2 \\
45.0 \\
57.6 \\
64.3 \\
63.9\end{array}$ & $\begin{array}{l}44.2 \\
51.9 \\
40.6 \\
53.3 \\
59.8 \\
57.8\end{array}$ & $\begin{array}{l}30.8 \\
39.4 \\
28.3 \\
40.8 \\
46.6 \\
40.2\end{array}$ & $\begin{array}{l}20.7 \\
25.9 \\
19.0 \\
26.7 \\
30.4 \\
27.0\end{array}$ \\
\hline
\end{tabular}

PV of debt-to-exports ratio

Baseline

$\begin{array}{llllllll}133.1 & 135.4 & 130.8 & 127.2 & 120.5 & 108.8 & 76.1 & 51.9\end{array}$

A. Alternative Scenarios

A1. Key variables at their historical averages in 2009-2029 1/

A2. New public sector loans on less favorable terms in 2009-2029 2

A3. Baseline with US $\$ 60$ million loan from China

A4. Baseline with US $\$ 60$ million loan from China and growth impact

B. Bound Tests

B1. Real GDP growth at historical average minus one standard deviation in 2010-2011 B2. Export value growth at historical average minus one standard deviation in 2010-2011 3/

B3. US dollar GDP deflator at historical average minus one standard deviation in 2010-2011

B4. Net non-debt creating flows at historical average minus one standard deviation in 2010-2011 4/

B5. Combination of B1-B4 using one-half standard deviation shocks

B6. One-time 30 percent nominal depreciation relative to the baseline in 2010 5/

\section{PV of debt-to-revenue ratio}

Baseline

\section{A. Alternative Scenarios}

A1. Key variables at their historical averages in 2009-2029 1/

A2. New public sector loans on less favorable terms in 2009-2029 2

A3. Baseline with US\$60 million loan from China

A4. Baseline with US\$60 million loan from China and growth impact

\section{B. Bound Tests}

B1. Real GDP growth at historical average minus one standard deviation in 2010-2011

B2. Export value growth at historical average minus one standard deviation in 2010-20113/

B3. US dollar GDP deflator at historical average minus one standard deviation in 2010-2011

B4. Net non-debt creating flows at historical average minus one standard deviation in 2010-2011 4/

B5. Combination of B1-B4 using one-half standard deviation shocks

B6. One-time 30 percent nominal depreciation relative to the baseline in 2010 5/

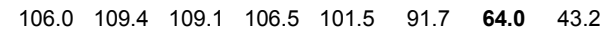

$\begin{array}{rrrrrrrr}133.1 & 125.7 & 119.2 & 116.3 & 112.5 & 107.0 & \mathbf{1 0 2 . 0} & 103.0 \\ 133.1 & 139.9 & 137.9 & 136.2 & 130.4 & 118.8 & \mathbf{8 9 . 1} & 78.7 \\ 133.1 & 146.0 & 151.0 & 156.7 & 149.7 & 137.9 & \mathbf{1 0 3 . 3} & 73.5 \\ 133.1 & 145.6 & 150.1 & 155.2 & 146.8 & 133.8 & \mathbf{9 5 . 8} & 64.5 \\ & & & & & & & \\ & & & & & & & \\ 133.1 & 135.4 & 130.8 & 127.2 & 120.5 & 108.8 & \mathbf{7 6 . 1} & 51.9 \\ 133.1 & 167.0 & 216.2 & 211.2 & 201.8 & 186.0 & \mathbf{1 4 1 . 9} & 94.8 \\ 133.1 & 135.4 & 130.8 & 127.2 & 120.5 & 108.8 & \mathbf{7 6 . 1} & 51.9 \\ 133.1 & 152.1 & 165.5 & 161.7 & 154.7 & 142.8 & \mathbf{1 0 9 . 8} & 73.1 \\ 133.1 & 167.3 & 214.7 & 209.9 & 201.3 & 186.8 & \mathbf{1 4 6 . 4} & 97.1 \\ 133.1 & 135.4 & 130.8 & 127.2 & 120.5 & 108.8 & \mathbf{7 6 . 1} & 51.9\end{array}$

$\begin{array}{llllllll}106.0 & 101.5 & 99.4 & 97.4 & 94.8 & 90.2 & \mathbf{8 5 . 8} & 85.6\end{array}$

$\begin{array}{rrrrrrrr}106.0 & 113.0 & 115.0 & 114.0 & 109.8 & 100.1 & \mathbf{7 4 . 9} & 65.5\end{array}$

$\begin{array}{llllllll}106.0 & 117.9 & 125.9 & 131.2 & 126.1 & 116.3 & \mathbf{8 6 . 9} & 61.1\end{array}$

$\begin{array}{llllllll}106.0 & 117.6 & 125.1 & 130.0 & 123.6 & 112.8 & \mathbf{8 0 . 5} & 53.6\end{array}$

$\begin{array}{llllllll}106.0 & 113.7 & 118.7 & 116.0 & 110.5 & 99.9 & \mathbf{6 9 . 7} & 47.0\end{array}$

$\begin{array}{llllllll}106.0 & 117.8 & 134.8 & 132.2 & 127.0 & 117.2 & \mathbf{8 9 . 2} & 58.9\end{array}$

$\begin{array}{llllllll}106.0 & 109.2 & 109.2 & 106.7 & 101.6 & 91.8 & \mathbf{6 4 . 1} & 43.2\end{array}$

$\begin{array}{llllllll}106.0 & 122.8 & 138.0 & 135.4 & 130.2 & 120.4 & \mathbf{9 2 . 3} & 60.7\end{array}$

$\begin{array}{llllllll}106.0 & 125.5 & 153.5 & 150.8 & 145.3 & 135.0 & \mathbf{1 0 5 . 6} & 69.2\end{array}$

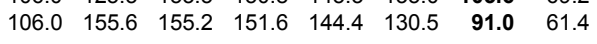

Source: Fund staff projections and simulations.

1/ Variables include real GDP growth, growth of GDP deflator (in U.S. dollar terms), non-interest current account in percent of GDP, and non-debt creating flows.

2/ Assumes that the interest rate on new borrowing is by 2 percentage points higher than in the baseline., while grace and maturity periods are the same as in the baseline.

3/ Exports values are assumed to remain permanently at the lower level, but the current account as a share of GDP is assumed to return to its baseline level after the shock

(implicitly assuming an offsetting adjustment in import levels).

4/ Includes official and private transfers and FDI.

5/ Depreciation is defined as percentage decline in dollar/local currency rate, such that it never exceeds 100 percent. 
Table 5b. Dominica: Sensitivity Analysis for Key Indicators of Public and Publicly Guaranteed External Debt, 2009-2029 (In percent)

Projections

$\begin{array}{llllllll}2009 & 2010 & 2011 & 2012 & 2013 & 2014 & 2019 & 2029\end{array}$

Debt service-to-exports ratio

Baseline

\section{A. Alternative Scenarios}

A1. Key variables at their historical averages in 2009-2029 1/

A2. New public sector loans on less favorable terms in 2009-2029 2

A3. Baseline with US\$60 million loan from China

A4. Baseline with US\$60 million loan from China and growth impact

\section{B. Bound Tests}

B1. Real GDP growth at historical average minus one standard deviation in 2010-2011 B2. Export value growth at historical average minus one standard deviation in 2010-2011 3/ B3. US dollar GDP deflator at historical average minus one standard deviation in 2010-2011 B4. Net non-debt creating flows at historical average minus one standard deviation in 2010-2011 4/ B5. Combination of B1-B4 using one-half standard deviation shocks

B6. One-time 30 percent nominal depreciation relative to the baseline in 20105 /

$\begin{array}{rrrrrrrr}16.1 & 11.7 & 11.4 & 10.1 & 9.4 & 12.4 & \mathbf{8 . 5} & 5.0 \\ & & & & & & & \\ 16.1 & 11.7 & 11.0 & 9.7 & 9.2 & 12.4 & \mathbf{9 . 9} & 8.4 \\ 16.1 & 11.7 & 11.4 & 10.4 & 9.9 & 12.9 & \mathbf{9 . 4} & 5.9 \\ 16.1 & 11.7 & 11.6 & 10.6 & 10.2 & 13.1 & \mathbf{1 1 . 1} & 7.7 \\ 16.1 & 11.7 & 11.6 & 10.5 & 10.0 & 12.7 & \mathbf{1 0 . 4} & 6.9\end{array}$

$\begin{array}{llllllll}16.1 & 11.7 & 11.4 & 10.1 & 9.4 & 12.4 & \mathbf{8 . 5} & 5.0\end{array}$ $\begin{array}{llllllll}16.1 & 13.4 & 15.7 & 15.1 & 14.3 & 18.2 & \mathbf{1 2 . 9} & 9.1\end{array}$

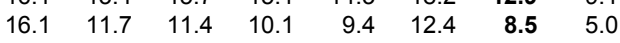
$\begin{array}{llllllll}16.1 & 11.7 & 12.0 & 11.5 & 10.8 & 13.7 & \mathbf{9 . 8} & 7.1\end{array}$ $\begin{array}{llllllll}16.1 & 12.8 & 14.7 & 14.5 & 13.7 & 17.3 & \mathbf{1 2 . 4} & 9.4\end{array}$

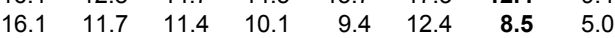

Debt service-to-revenue ratio

\section{Baseline}

$\begin{array}{llllllll}12.9 & 9.5 & 9.5 & 8.4 & 7.9 & 10.4 & \mathbf{7 . 1} & 4.1 \\ & & & & & & & \\ 12.9 & 9.4 & 9.2 & 8.1 & 7.7 & 10.5 & \mathbf{8 . 3} & 7.0 \\ 12.9 & 9.5 & 9.5 & 8.7 & 8.3 & 10.9 & \mathbf{7 . 9} & 4.9 \\ 12.9 & 9.5 & 9.7 & 8.9 & 8.6 & 11.1 & \mathbf{9 . 3} & 6.4 \\ 12.9 & 9.5 & 9.6 & 8.8 & 8.4 & 10.7 & \mathbf{8 . 8} & 5.7\end{array}$

\section{B. Bound Tests}

B1. Real GDP growth at historical average minus one standard deviation in 2010-2011 B2. Export value growth at historical average minus one standard deviation in 2010-2011 3/ B3. US dollar GDP deflator at historical average minus one standard deviation in 2010-2011 B4. Net non-debt creating flows at historical average minus one standard deviation in 2010-2011 4/ B5. Combination of B1-B4 using one-half standard deviation shocks

B6. One-time 30 percent nominal depreciation relative to the baseline in 2010 /

$\begin{array}{rrrrrrrr}12.9 & 9.9 & 10.3 & 9.2 & 8.6 & 11.4 & \mathbf{7 . 7} & 4.5 \\ 12.9 & 9.5 & 9.8 & 9.5 & 9.0 & 11.5 & \mathbf{8 . 1} & 5.7 \\ 12.9 & 9.5 & 9.5 & 8.4 & 8.0 & 10.4 & \mathbf{7 . 1} & 4.1 \\ 12.9 & 9.5 & 10.0 & 9.6 & 9.1 & 11.6 & \mathbf{8 . 2} & 5.9 \\ 12.9 & 9.6 & 10.5 & 10.4 & 9.9 & 12.5 & \mathbf{8 . 9} & 6.7 \\ 12.9 & 13.5 & 13.5 & 12.0 & 11.3 & 14.8 & \mathbf{1 0 . 1} & 5.9\end{array}$

Memorandum item:

Grant element assumed on residual financing (i.e., financing required above baseline) 6/ 18

1818

Source: Fund staff projections and simulations.

1/ Variables include real GDP growth, growth of GDP deflator (in U.S. dollar terms), non-interest current account in percent of GDP, and non-debt creating flows.

2/ Assumes that the interest rate on new borrowing is by 2 percentage points higher than in the baseline., while grace and maturity periods are the same as in the baseline. 3/ Exports values are assumed to remain permanently at the lower level, but the current account as a share of GDP is assumed to return to its baseline level after the shock (implicitly assuming an offsetting adjustment in import levels).

4 / Includes official and private transfers and FDI.

5/ Depreciation is defined as percentage decline in dollar/local currency rate, such that it never exceeds 100 percent. 
Figure 1. Dominica: Indicators of Public Debt Under Alternative Scenarios, 2009-29 1/
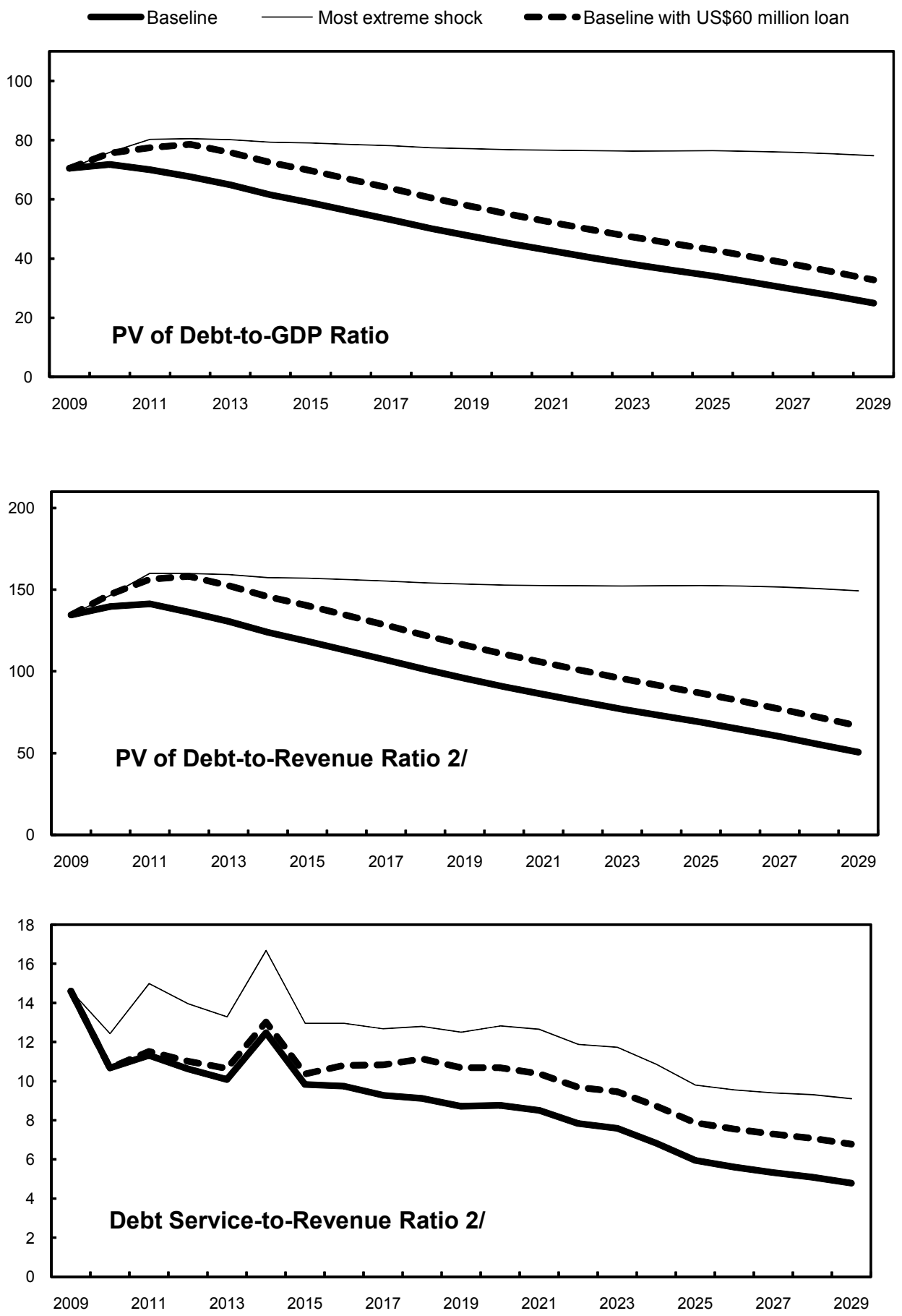

Sources: Country authorities; and Fund staff estimates and projections.

1/ The most extreme stress test is the test that yields the highest ratio in 2019.

2/ Revenues are defined inclusive of grants. 
Figure 2. Dominica: Indicators of Public and Publicly Guaranteed External Debt under Alternatives Scenarios, 2009-29 1/
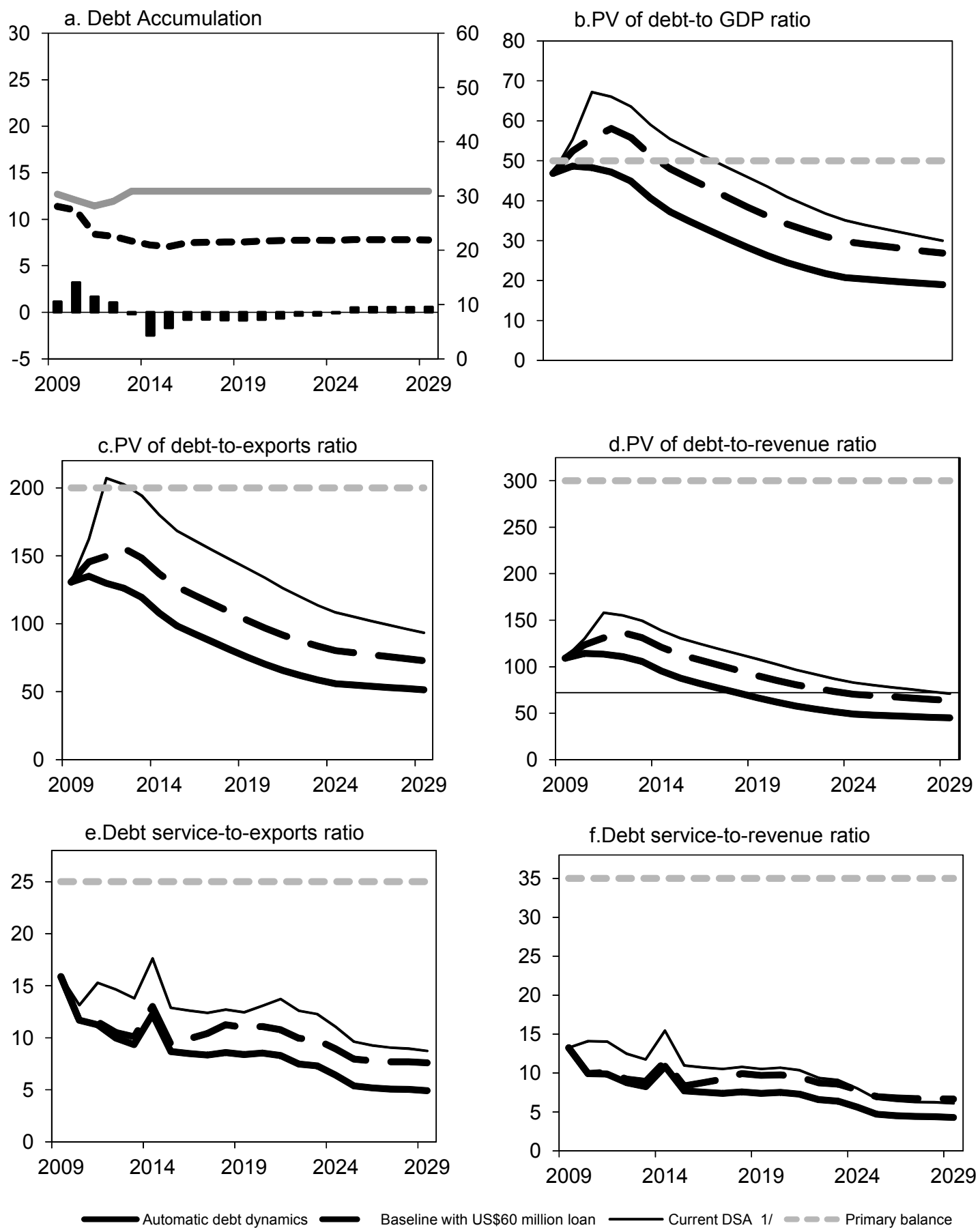

Sources: Staff projections and simulations

$1 /$ The most extreme stress test is the test that yields the highest ratio in 2019. In figure $b$. it corresponds to a Combination shock; in c. to a Combination shock; in d. to a Combination shock; in e. to a Exports shock and in picture f. to a One-time depreciation shock 


\section{INTERNATIONAL MONETARY FUND \\ DOMINICA \\ Staff Report for the 2010 Article IV Consultation \\ Informational Annex \\ Prepared by the Western Hemisphere Department}

April 27, 2010

Contents

Page

Appendices

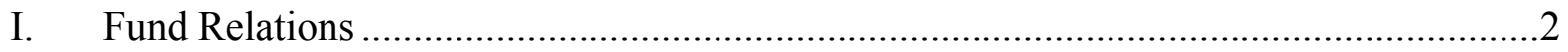

II. World Bank Relations .................................................................................

III. Relations with the Caribbean Development Bank (CDB) ......................................

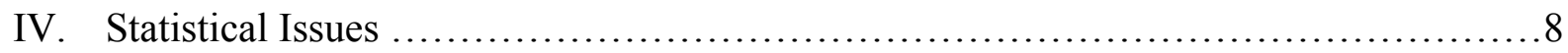




\section{Appendix I. Dominica: Fund Relations}

(As of March 31, 2010)

I. Membership Status Joined 12/12/78; Article VIII

II. General Resources Account

Quota

Fund holdings of currency

Reserve position in Fund

III. SDR Department

Net cumulative allocation

Holdings

IV. Outstanding Purchases and Loans:

Emergency Assistance

ESF RAC Loan

ECF Arrangements
SDR Million

8.20

10.24

0.01

SDR Million

7.84

6.94

SDR Million

2.05

3.28

7.12
Percent of Quota

100.00

124.90

0.11

Percent of Allocation

100.00

88.57

Percent of

Quota

25.00

40.00

86.88

V. Latest Financial Arrangements:

\begin{tabular}{lcccr} 
Type & $\begin{array}{c}\text { Approval } \\
\text { Date }\end{array}$ & $\begin{array}{c}\text { Expiration } \\
\text { Date }\end{array}$ & \multicolumn{2}{c}{$\begin{array}{c}\text { Amount } \\
\text { Approved }\end{array}$} \\
& & & \multicolumn{2}{c}{$\begin{array}{c}\text { Amount Dras } \\
\text { (SDR Million) }\end{array}$} \\
ECF & $12 / 29 / 03$ & $12 / 28 / 06$ & 7.69 & 7.69 \\
Stand-By & $08 / 28 / 02$ & $01 / 02 / 04$ & 2.97 & 2.97 \\
SAF & $11 / 26 / 86$ & $11 / 25 / 89$ & 2.80 & 2.80
\end{tabular}

Projected Payments to the Fund on an Obligation Basis (SDR Million) ${ }^{1}$ :

\begin{tabular}{lcccrr} 
& & \multicolumn{4}{c}{ Forthcoming } \\
& $\mathbf{2 0 1 0}$ & $\mathbf{2 0 1 1}$ & $\mathbf{2 0 1 2}$ & $\mathbf{2 0 1 3}$ & $\mathbf{2 0 1 4}$ \\
Principal & 0.66 & 1.84 & 2.56 & 1.79 & 1.04 \\
Charges/Interest & 0.02 & 0.03 & 0.03 & 0.02 & 0.02 \\
Total & $\mathbf{0 . 6 8}$ & $\mathbf{1 . 8 7}$ & $\mathbf{2 . 6 0}$ & $\mathbf{1 . 8 1}$ & $\mathbf{1 . 0 5}$
\end{tabular}

VI. Exchange rate arrangement: Dominica is a member of the Eastern Caribbean Currency Union, which has a common central bank (the Eastern Caribbean Central Bank) and currency (the Eastern Caribbean dollar). Since July 1976, the Eastern Caribbean dollar has been pegged to the U.S. dollar at the rate of EC $\$ 2.70$ per U.S. dollar.

\footnotetext{
${ }^{1}$ Based on existing use of resources and present holdings of SDRs.
} 
Safeguards Assessment: Under the Fund's safeguards assessment policy, the Eastern Caribbean Central Bank (ECCB), of which Dominica is a member, is subject to a full safeguards assessment under a four year cycle. The most recent assessment was completed in July 2007, and concluded that the ECCB continues to have appropriate control mechanisms in place, which have strengthened since the first safeguards assessment completed in 2003. ECCB management places emphasis on good governance and sound controls, and has enhanced the bank's transparency and accountability since the last assessment, including the publications of financial statements that comply with International Financial Reporting Standards. The assessment made some recommendations to sustain the ECCB's safeguards framework going forward.

VII. Article IV consultation: The last Article IV consultation was concluded by the Executive Board on July 30, 2008; the relevant document is IMF Country Report No. 08/310. Dominica is on a 12-month cycle.

VIII. Technical assistance: In December 2009 and August 2009 a Caribbean Regional Technical Assistance Center (CARTAC) mission provided technical assistance on National Income Accounts Statistics aimed at rebasing the GDP constant price estimates to 2006. In October 2009, an MCM mission provided technical assistance on improving the debt management capacity of the government. In January/February 2009 an FAD mission provided technical assistance on ongoing customs and tax administration reforms including issues of capacity building, organizational restructuring for greater effectiveness and efficiency, and considerations of revenue authority (RA) options. In September 2007 an FAD mission reviewed the tax policy aspects of the value-added (VAT) and excises and provided advice to the authorities on possible reforms. In January 2007 an FAD and CARTAC mission provided technical assistance on revenue administration and tax policy. In 2006, an MCM mission provided technical assistance in drafting an action plan for AID Bank. In 2005, an MCM mission provided technical assistance in strengthening the supervisory framework for AML/CFT in the nonbank sector. FAD missions have provided technical assistance on tax policy and administration, and social security reform. The most recent missions include: pension reform options (2005); TA on fiscal responsibility laws (2004); VAT implementation (1999); urban property taxation (1997); and tax policy and administration, and expenditure control (1995). Technical assistance from MCM and FAD has complemented the assistance that has been provided by the CARTAC in Barbados. LEG has been providing assistance with the drafting and interpretation of the VAT legislation.

IX. FSAP: A joint IMF/World Bank team performed an assessment of the financial sector of the member states of the ECCB, in two missions-September 1-19 and October 20-31, 2003. The principal objective of the missions was to assist the authorities in assessing the development needs and opportunities for the financial sector and identifying potential vulnerabilities of financial institutions and markets to macroeconomic shocks, as well as the risks to macroeconomic stability from weaknesses and shortcomings in the financial sector. A detailed assessment of the AML/CFT regimes of Dominica was conducted in September 2003 by the Caribbean Financial Action Task Force (CFATF). The Financial System Stability Assessment (FSSA) was discussed by the Executive Board on May 5, 2004, and subsequently published on the IMF's external website, including the Report on the Observance of Standards and Codes (ROSC) on Banking Supervision. 


\section{Appendix II. Dominica: Relations with the World Bank Group}

(As of February 16, 2010)

The World Bank is in the process of elaborating its Eastern Caribbean Sub-Regional Partnership Strategy for FY10-14 and it is scheduled to be presented to the Board of the Bank in May 2010. The interventions elaborated on below were launched under the Bank's Eastern Caribbean Sub-Region Country Assistance Strategy (CAS) for FY06-09. The FY06-09 Strategy supported the sub-region's development agenda through two main pillars: (1) stimulating growth and improving competitiveness; and (2) reducing vulnerability, by promoting greater social inclusion and strengthening disaster risk management. Recognizing the OECS countries' weakened creditworthiness due to high debt ratios, Bank activities focused on leveraging available donor grant financing. The OECS countries have confirmed that the objectives under the FY06-09 Strategy remain relevant.

\section{Projects}

There are currently four active Bank projects in Dominica for a net commitment of approximately US\$8.89 million:

The OECS E-Government for Regional Integration Program was approved by the Board in May 2008. This project consists of a US\$2.4 million loan to Dominica and is designed to promote the efficiency, quality, and transparency of public services through the delivery of regionally integrated e-government applications that take advantage of economies of scale. The program is structured in phases. Phase 1 focuses on cross-sectoral e-government issues, as well as on specific applications in the public finance area (including public financial management, tax, customs and procurement), and also includes an e-government in health pilot project (possibly together with preparatory and complementary activities in other social and productive sectors). Subsequent phases of the program are expected to deepen the assistance provided under Phase 1, while expanding the program to cover other sectors, in particular, health, education, agriculture, tourism, postal, among others that may emerge during the early stages of implementation of Phase 1.

The Growth and Social Protection Technical Assistance Project was approved in February 2007 for US\$1.45 million. The objectives of the project are to enhance the capacity of the public sector to implement focused reforms geared at improving the public sector delivery of services as well as creating the institutional and policy framework to facilitate private sector-led growth. The project has the following five components: Component (1) focuses on making the public sector more efficient and effective through support to implement the government's public sector modernization strategy; Component (2) targets improvement of the investment climate through the strengthening of the institutional and regulatory framework for attracting investment into Dominica; Component (3) focuses on reforming the regulatory framework for the energy sector and support the creation of a framework for the development of alternative sources of energy; Component (4) addresses the improvement of the existing social safety net programs; Component (5) deals with the management of the overall project. The total project cost is 
US\$2.6 million, of which the Bank is providing US\$1.45 million and the EU is providing US\$0.58 million of grant financing.

The Caribbean Catastrophe Risk Insurance Project was approved in January 2007. This is the world's first ever multi-country catastrophe insurance pool. The Bank has approved a US\$4.5 million IDA credit for Dominica to finance their contribution to the fund over three years. The Facility will enable governments to purchase catastrophe insurance coverage against adverse natural events, such as a major earthquake or hurricane. The CCRIF allows participating countries to pool their country-specific risks into one, better-diversified portfolio, resulting in a substantial reduction in the premium cost of $45-50$ percent.

The OECS Telecommunications and ICT Development Project was approved in September, 2005 for US\$541.6 thousand and aims at improving the access, quality, and use of telecommunications and ICT services to achieve socio-economic development in the OECS. The project has the following four components: Component (1) aims to strengthen the national and regional regulatory frameworks and promote additional competition in the telecommunications sector. Emphasis will be given to capacity building of Eastern Caribbean Telecommunications Authority (ECTEL) and the National Telecommunications Regulatory Commissions (NTRCs) by providing them with assistances to revise the regional and national sector legislation, and develop a modem interconnection regime; Component (2) supports the review current universal access policy, create related guidelines, and provide financial support to establish a Universal Service Fund (USF); Component (3) aims to improve growth and competitiveness in ICTenabled services through utilization of broadband infrastructure; and Component (4) supports management and administration of the overall project.

\section{Economic and Sector Work}

The Bank has completed a series of analytical studies relating to public sector capacity in the OECS including a number of Public Expenditure Reviews, an Institutional and Organizational Capacity Review and, in late 2007, a Country Fiduciary Assessment. The Bank also prepared an OECS study on Growth and Competitiveness (2005), an OECS Skills Enhancement Policy Note (2006), a Caribbean Air Transport Report (2006), and a regional study on Crime, Violence, and Development: Trends, Costs, and Policy Options in the Caribbean (2007). In addition, an OECS Private Sector Financing Study and the OECS Tourism Backward Linkages Study were completed in 2008. The publication "Caribbean-Accelerating Trade Integration: Policy Options for Sustained Growth, Job Creation and Poverty Reduction" was released in the summer of 2009.

Dominica will also benefit from ongoing and planned analytical and advisory activities including the following: a CARICOM study on Managing Nurse Migration and a preparatory study aimed at developing a Caribbean-wide Regional Energy Strategy. 
III. Financial Relations:

(In millions of U.S. dollars)

\begin{tabular}{|l|c|c|c|}
\hline Operation & $\begin{array}{c}\text { Original } \\
\text { Principal }\end{array}$ & Available $^{\mathbf{1}}$ & Disbursed $^{\mathbf{1}}$ \\
\hline $\begin{array}{l}\text { The OECS E-Government for Regional } \\
\text { Integration Program }\end{array}$ & 2.40 & 2.13 & 0.17 \\
\hline The OECS Catastrophe Risk Insurance & 4.50 & 0.73 & 3.88 \\
\hline $\begin{array}{l}\text { Growth and Social Protection Technical } \\
\text { Assistance Credit }\end{array}$ & 1.45 & 0.39 & 1.14 \\
\hline $\begin{array}{l}\text { OECS Telecommunications and ICT } \\
\text { Development Project }\end{array}$ & 0.54 & 0.30 & 0.31 \\
\hline Total & $\mathbf{8 . 8 9}$ & $\mathbf{3 . 5 5}$ & $\mathbf{5 . 5 0}$ \\
\hline
\end{tabular}

1/ Amounts may not add up to Original Principal due to changes in the SDR/US exchange rate since signing.

\section{Disbursements and Debt Service (Fiscal Year)}

\begin{tabular}{|l|r|r|r|r|r|r|r|r|r|r|}
\hline & $\mathbf{2 0 0 1}$ & $\mathbf{2 0 0 2}$ & $\mathbf{2 0 0 3}$ & $\mathbf{2 0 0 4}$ & $\mathbf{2 0 0 5}$ & $\mathbf{2 0 0 6}$ & $\mathbf{2 0 0 7}$ & $\mathbf{2 0 0 8}$ & $\mathbf{2 0 0 9}$ & $\mathbf{2 0 1 0} *$ \\
\hline Total disbursements & 0.5 & 1.5 & 2.8 & 3.9 & 1.6 & 0.0 & 1.3 & 1.3 & 0.6 & 1.3 \\
\hline Repayments & 0.1 & 0.1 & 0.3 & 0.6 & 0.7 & 0.8 & 1.0 & 1.28 & 1.2 & 0.7 \\
\hline Net disbursements & 0.4 & 1.4 & 2.5 & 3.4 & 0.9 & -0.8 & 0.2 & 0.02 & -0.6 & 0.6 \\
\hline Interest and fees & 0.3 & 0.3 & 0.3 & 0.4 & 0.4 & 0.4 & 0.4 & 0.3 & 0.3 & 0.2 \\
\hline
\end{tabular}

*Data as of February 16, 2010 


\section{Appendix III. Dominica: Relations with the Caribbean Development Bank (CDB)}

(As of December 31, 2009)

CDB has played a significant role in Dominica's development process. Bank support has been provided through the provision of investment loans, policy-based loans and TA grants. The Bank has also extensively utilized its Basic Needs Trust Fund as a key modality for direct poverty intervention programs. Significant support was provided towards the expansion of the productive capacity of the economy, as well as strengthening HRD and reducing poverty. In particular, support has been provided to strengthen economic management systems, expand agricultural output, improve critical road infrastructure, upgrade ecotourism-related sites and attractions, promote shelter development and interventions to support development in the indigenous Carib territory. Disaster rehabilitation works have also represented a consistent element of past interventions.

Over the period 1970-2009, total loans and grants approved for Dominica stood at USD194.9 million, making it the eighth largest beneficiary of resources from the Bank. At the end of 2009, CDB's exposure to Dominica was USD82.4 million, which represented $6.1 \%$ of CDB's total disbursed debt outstanding. However, lending to the country has stagnated over the four-year period to 2008. Following its debt restructuring exercise in 2004, GOCD has been hesitant to engage in borrowing. The fiscal policy stance has become increasingly prudent, as greater reliance has been placed on grant receipts to fund Government's development program. The policy has been relatively successful. Grants as a share of GDP have increased to record levels (in excess of 10\%) allowing public sector investment to climb significantly above historical averages. This has facilitated a relatively long growth spurt, together with an improved debt profile. The challenge for Dominica, and in some respects the opportunity, is to translate these transitory flows into positive medium to long-term development impacts.

Given the aging portfolio, net resource flows to CDB turned negative in 2007 and 2008, but recovered marginally in 2009 (see Table below). Disbursements declined from an average of USD6.3 million (excluding 2003 and 2004) to under USD3.0 million. Disbursements in 2003 and 2004 were abnormally high and represented CDB's support to Dominica during the crisis period. In 2003 the Bank provided a single tranche Economic Stabilization Loan (USD3.0 million) followed by provision of exceptional finance (USD14.9 million) in 2004.

Dominica: Loan Disbursement

(In millions of U.S. dollars)

\begin{tabular}{|l|c|c|c|c|c|c|c|c|}
\hline & $\mathbf{2 0 0 2}$ & $\mathbf{2 0 0 3}$ & $\mathbf{2 0 0 4}$ & $\mathbf{2 0 0 5}$ & $\mathbf{2 0 0 6}$ & $\mathbf{2 0 0 7}$ & $\mathbf{2 0 0 8}$ & $\mathbf{2 0 0 9}$ \\
\hline Net disbursement & 3.66 & 8.46 & 10.39 & 3.99 & 0.91 & -1.07 & -1.50 & 0.32 \\
\hline Disbursement & 6.25 & 11.26 & 20.61 & 6.34 & 2.14 & 2.36 & 3.20 & 4.23 \\
\hline Amortization & 2.59 & 2.80 & 10.22 & 2.35 & 1.23 & 3.43 & 4.70 & 3.93 \\
\hline Interest and charges & 1.90 & 2.03 & 2.25 & 2.44 & 1.54 & 2.95 & 2.20 & 2.23 \\
\hline Net resource flow & 1.76 & 6.43 & 8.14 & 1.55 & -0.63 & -4.02 & -3.90 & -1.93 \\
\hline
\end{tabular}




\section{Appendix IV. Dominica: Statistical Issues}

While data provision for surveillance purposes is broadly adequate, certain areas need to be improved. There are weaknesses in coverage, accuracy, frequency, and timeliness that continue to hamper effective economic analysis and policy formulation. Priority should need to be given to compilation and dissemination of national accounts, in particular tourism, agriculture and labor statistics. Despite progress significant weaknesses remain in the compilation of fiscal accounts, and the balance of payments.

Dominica participates in the General Data Dissemination System. However the metadata for national accounts, external sector and government finance statistics have not been updated since December 2002.

\section{Real sector}

Annual nominal GDP data are compiled using the production and the expenditure approaches. Estimates by economic activity are compiled using production approach at 1990 prices. GDP estimates are available about four months after the end of the year. The data are revised frequently and are usually finalized with a two-year lag following completion of the National Accounts Survey. There is an ongoing project to improve national accounts data which involves rebasing to 2006 and expanding the basket with the Assistance of CARTAC and the ECCB. The newly revised GDP is expected to be released by February 2010. CPI data are compiled with a two-month lag. The weights are based on the 1997/1998 Household Expenditure Survey. There is a program to develop export and import price indices (XMPIs), but a shortage of staff working on price statistics limits developments in CPI methodology and the likelihood that XMPIs will be developed in the near future. Data on employment are limited and there are no official data on producer prices or wages in the private sector. Results of the 2001 population census have not yet been published.

\section{Government finance}

Statistical capacity problems affect the timely production of quality government finance statistics. In particular, the data are subject to frequent revisions stemming in part from omissions and misclassifications. Data on central government operations are incomplete and must be supplemented with additional information from external sources. For instance, some operations are undertaken outside the consolidated fund. These include certain investment spending, loan and grant receipts, and on-lending and transfers to public enterprises. As a result, capital expenditure data, recorded by the Treasury, must be supplemented with additional donor financing information, particularly because the public sector investment program (PSIP) data are not timely. Delays in the reporting of the PSIP data reportedly stem from reporting delays from the line ministries.

Several ongoing initiatives to strengthen expenditure management should help minimize the extent of this problem. There is an ongoing effort to automate the expenditure execution process. A new automation technology was installed in all line ministries in 2005. With this technology 
all local purchase orders (LPOs) are generated electronically and tracked. Commitments are charged against a specific budget allocation once the LPOs are generated. All ministries and suppliers of goods and services are compelled to use the new system.

Only limited financing data are available. Although progress has been made in improving the measurement of the government's debt, there are concerns that there is still some under-recording of government commitments.

The authorities do not provide consolidated nonfinancial public sector data. Data for the rest of the public sector-Dominica Social Security and the public enterprises - must be obtained directly from each entity during Fund Article IV consultation missions.

No government finance data are reported to STA for publication in the International Financial Statistics (IFS) or the Government Finance Statistics (GFS) Yearbook.

\section{Monetary statistics}

Monetary statistics are compiled and reported to the Fund by the ECCB on a monthly basis based on a standardized report form since July 2006. The institutional coverage of monetary statistics needs to be improved by including the accounts of mortgage companies, building societies, credit unions, and insurance companies. In this respect, close coordination between the ECCB and the single regulatory unit (which supervises financial corporations other than those licensed under the Banking Act) is crucial.

\section{Balance of payments}

Balance of payments data are compiled by the ECCB on an annual basis but are not reported in the format recommended in the fifth edition of the IMF's Balance of Payments Manual. Data reported to STA are becoming more timely, but still suffer from relatively numerous and volatile errors and omissions.

\section{External debt}

The Ministry of Finance maintains a database on public and publicly-guaranteed external loans that provides detailed and reasonably current information on disbursements, debt service, and debt stocks. The Treasury maintains the data on bonds placed abroad. Data from the two databases are not consolidated, requiring further adjustments to measure total debt stock. In addition, information on payments by creditor (actual and scheduled) should be available to the compilation agencies at least on a monthly basis, in order to produce timely debt stock data. 
Dominica: Table of Common Indicators Required for Surveillance

(As of April 27, 2010)

\begin{tabular}{|c|c|c|c|c|c|}
\hline & $\begin{array}{l}\text { Date of latest } \\
\text { observation }\end{array}$ & Date received $^{7}$ & $\begin{array}{l}\text { Frequency of } \\
\text { Data }^{7}\end{array}$ & $\begin{array}{l}\text { Frequency of } \\
\text { Reporting } 7\end{array}$ & $\begin{array}{l}\text { Frequency of } \\
\text { Publication }\end{array}$ \\
\hline Exchange Rates ${ }^{1}$ & Fixed Rate & NA & NA & NA & NA \\
\hline $\begin{array}{l}\text { International Reserve Assets and Reserve Liabilities of the } \\
\text { Monetary Authorities } 1,2\end{array}$ & February 2010 & $4 / 12 / 10$ & M & M & $Q$ \\
\hline Reserve/Base Money & February 2010 & $4 / 12 / 10$ & M & M & Q \\
\hline Central Bank Balance Sheet & February 2010 & $4 / 12 / 10$ & M & M & $\mathrm{Q}$ \\
\hline Consolidated Balance Sheet of the Banking System & February 2010 & $4 / 12 / 10$ & M & M & Q \\
\hline Interest Rates ${ }^{3}$ & February 2010 & $4 / 12 / 10$ & Q & Q & Q \\
\hline Consumer Price Index & February 2010 & $4 / 08 / 10$ & M & M & M \\
\hline $\begin{array}{l}\text { Stocks of Central Government and Central Government-Guaranteed } \\
\text { Debt }^{6}\end{array}$ & June 2009 & $11 / 13 / 09$ & M & M & $A$ \\
\hline External Current Account Balance & 2008 & $12 / 10 / 09$ & A & A & A \\
\hline Exports and Imports of Goods and Services & 2008 & $12 / 10 / 09$ & $A$ & $A$ & $A$ \\
\hline GDP/GNP & 2008 & 01/18/10 & A & A & A \\
\hline Gross External Debt & June 2009 & $11 / 13 / 09$ & M & M & A \\
\hline
\end{tabular}

${ }^{1}$ Dominica is a member of the Eastern Caribbean Currency Union, in which the common currency of all member states (E.C. dollar) is pegged to the U.S. dollar at US\$1=EC $\$ 2.70$.

${ }^{2}$ Includes reserve assets pledged or otherwise encumbered as well as net derivative positions.

${ }^{3}$ Both market-based and officially-determined, including discount rates, money market rates, rates on treasury bills, notes and bonds.

${ }^{4}$ Foreign, domestic bank, and domestic nonbank financing.

${ }^{5}$ The general government consists of the central government and state and local governments.

${ }^{6}$ Currency and maturity composition are provided annually.

${ }^{7}$ Daily (D), Weekly (W), Monthly (M), Quarterly (Q), Annually (A); Irregular (I); Not Available (NA); Not applicable (n.a). 


\section{INTERNATIONAL MONETARY FUND}

EXTERNAL

Public Information Notice (PIN) No. 10/63

FOR IMMEDIATE RELEASE

May 25, 2010

International Monetary Fund

$70019^{\text {th }}$ Street, NW

Washington, D. C. 20431 USA

\section{IMF Executive Board Concludes 2010 Article IV Consultation with Dominica}

On May 10, 2010, the Executive Board of the International Monetary Fund (IMF) concluded the Article IV consultation with Dominica. ${ }^{1}$

\section{Background}

The global downturn has adversely affected the Dominican economy through lower tourism arrivals, foreign direct investment inflows and remittances, although less severely than other Eastern Caribbean Currency Union (ECCU) economies. Real Gross Domestic Product is estimated to have declined by only 0.3 percent in 2009 . Total tourism receipts contracted by 16 percent during 2009. This decline reflected falling stayover arrivals after the Reunion 2008 event and greater discounting in 2009 partly offset by growth in cruise arrivals. FDI and remittances inflows dropped by 51 percent and 18 percent respectively in 2009.

\footnotetext{
${ }^{1}$ Under Article IV of the IMF's Articles of Agreement, the IMF holds bilateral discussions with members, usually every year. A staff team visits the country, collects economic and financial information, and discusses with officials the country's economic developments and policies. On return to headquarters, the staff prepares a report, which forms the basis for discussion by the Executive Board. At the conclusion of the discussion, the Managing Director, as Chairman of the Board, summarizes the views of Executive Directors, and this summary is transmitted to the country's authorities. An explanation of any qualifiers used in summings up can be found here: http://www.imf.org/external/np/sec/misc/qualifiers.htm.
} 
In response to the global slowdown, the government decided to maintain capital spending in 2009 at the high post-hurricane level in 2008. Despite high capital spending, the overall fiscal position remained in surplus during FY 2008/09 (July-June) and so far in FY 2009/10. This reflects primarily continuing strong performance of the VAT introduced in 2006. The strong performance also helped finance a scaling up of social assistance to protect the poor from the effects of the 2008 spike in food and fuel prices and the global economic slowdown.

Consumer price inflation has picked up recently. The Consumer Price Index (CPI) increased by 4.4 percent (yoy) through February 2010, as increases in world food and fuel prices were passed through. This reflected a pick up in the later part of the year. On a period average basis, inflation was close to zero.

The external current account deficit decreased to 28 percent of GDP in 2009. In 2008, the deficit had widened to 32 percent of GDP due to higher reconstruction-related and fuel imports, which were mostly financed by external grants and FDI. Lower FDI-related and fuel imports in 2009 are estimated to have more than offset lower tourism receipts and remittances. To mitigate the adverse impact of the global downturn on the balance of payments, the Executive Board on July 10, 2009 approved a disbursement of SDR 3.28 million (about US $\$ 5.1$ million) under the Rapid-Access Component of the Exogenous Shocks Facility.

Monetary aggregates show steady growth and the banking system has remained resilient. In the 12 months to December 2009, banking sector credit to the private sector grew by 6.9 percent and broad money by 10 percent. Prudential indicators suggest that banks are liquid and well capitalized, with declining nonperforming loans. The average nonperforming loans ratio and capital-based soundness indicators remain above prudential norms, although returns on assets have declined markedly in recent years.

The collapse of the Trinidad and Tobago-based CL Financial Group has exposed regional weaknesses in the regulation of nonbanks. The eight KPMG judicial managers appointed in each ECCU jurisdiction for the British American Insurance Company (BAICO) issued a joint report in October 2009 finding that the company is insolvent and illiquid. The ECCU member authorities are making progress in the creation of a new company to take over BAICO's operations in the region.

The near to medium-term economic outlook is modestly positive. With the recovery of the global economy and expected improvements in international trade and tourism activities, the Dominican economy is expected to grow by $1 \frac{1}{2} 2$ percent in 2010 . The downside risks are related to a potentially very slow recovery in advanced economies, which would adversely affect tourism activity. In addition, a rebalancing of global demand could imply weaker demand for tourism services from Dominica's main source markets. 


\section{Executive Board Assessment}

The Executive Directors noted that the Dominican economy has been more resilient to the global crisis than other ECCU countries and that its near- to medium-term outlook is positive. Directors welcomed the authorities' Growth and Social Protection Strategy, which is appropriately aimed at guiding the economy toward fostering growth and reducing poverty while lowering public debt. Downside risks relate to a slower global recovery, possibly implying weaker demand for tourism.

Directors commended the authorities' prudent fiscal policy stance in recent years, which has placed public debt on a declining path and allowed the government to respond to the global downturn by keeping capital spending in 2009 at high levels. They encouraged the authorities to reduce the debt-to-GDP ratio further, thus maintaining the ability to respond to external shocks.

Most Directors expressed concern that the large externally financed projects could significantly slow the pace of decline in the debt-to-GDP ratio. While the likely departure from the fiscal anchor of a primary surplus of 3 percent of GDP implied by a loan for education and infrastructure projects is expected to be temporary, it risks undermining fiscal performance in the coming years. Directors encouraged the authorities to return rapidly to the fiscal anchor that has served the economy well. The expenditure that the authorities have contemplated on a large new tourism project carries considerable commercial risks. Directors recommended conducting an objective and independent assessment of the project, obtaining financing on concessional terms where feasible and - if the project proceeds - exploring partnerships with the private sector. A few Directors were of the view that some flexibility in borrowing and a temporary deviation from the declining debt trend with prudent policies should not be ruled out.

Directors stressed the importance of strengthening the supervision of the financial sector, including on-site examination of the insurance companies and credit unions. They welcomed the establishment of a single regulatory unit for the nonbank sector. Directors also welcomed the authorities' regional approach to address the collapse of the Trinidad and Tobago-based CL Financial Group and recommended that the resolution strategy should avoid systemic spillovers while minimizing fiscal costs.

Directors recognized the recent considerable progress with structural reforms and noted that sustained efforts, geared toward improving the business climate, will be critical for achieving the growth target. 
Dominica: Selected Economic and Social Indicators

\begin{tabular}{|c|c|c|c|c|c|}
\hline & \multirow[b]{2}{*}{2006} & \multirow[b]{2}{*}{2007} & \multirow{2}{*}{$\begin{array}{l}\text { Prel. } \\
2008\end{array}$} & \multicolumn{2}{|c|}{ Proj. } \\
\hline & & & & 2009 & 2010 \\
\hline \multicolumn{6}{|c|}{ (Annual percentage change, unless otherwise specified) } \\
\hline \multicolumn{6}{|l|}{ Output and prices } \\
\hline Real GDP & 4.8 & 2.5 & 3.2 & -0.3 & 1.4 \\
\hline GDP deflator & -0.1 & 2.1 & 2.6 & -0.3 & 2.0 \\
\hline Consumer prices (end of period) & 1.8 & 6.0 & 2.1 & 3.2 & 1.5 \\
\hline \multicolumn{6}{|l|}{ Money and credit $1 /$} \\
\hline Net foreign assets of the banking system & 15.6 & 5.7 & 3.9 & 6.0 & 3.0 \\
\hline $\begin{array}{l}\text { Net domestic assets of the banking system } \\
\text { Of which }\end{array}$ & -5.7 & 4.0 & 0.4 & 4.0 & 2.6 \\
\hline Net credit to the nonfinancial public & -8.8 & -3.2 & -0.3 & -1.6 & -2.9 \\
\hline Credit to the private sector & 7.6 & 3.4 & 5.5 & 4.8 & 5.4 \\
\hline Liabilities to the private sector (M2) & 9.9 & 9.7 & 4.3 & 10.0 & 5.6 \\
\hline \multicolumn{6}{|l|}{ Balance of payments } \\
\hline Merchandise exports, f.o.b. & 3.1 & -11.7 & -7.2 & -6.4 & 5.6 \\
\hline Merchandise imports, f.o.b. & 0.6 & 17.3 & 14.5 & -11.6 & -0.7 \\
\hline \multicolumn{6}{|l|}{ Real effective exchange rate } \\
\hline (end of period, depreciation -) & -0.6 & -2.0 & -1.5 & 1.9 & . \\
\hline Central government $3 /$ & \multicolumn{5}{|c|}{ (In percent of GDP) } \\
\hline Revenue & 32.7 & 33.4 & 34.6 & 35.6 & 35.7 \\
\hline Grants 4/ & 7.5 & 11.3 & 11.6 & 11.3 & 8.2 \\
\hline Capital expenditure and net lending & 9.9 & 14.2 & 16.0 & 16.0 & 15.4 \\
\hline Primary balance $4 /$ & 5.8 & 4.6 & 3.1 & 3.0 & 1.2 \\
\hline Overall balance 4/ & 3.6 & 2.2 & 0.9 & 0.8 & -1.2 \\
\hline Nonfinancial public sector debt (gross) $5 /$ & 95.7 & 90.9 & 84.9 & 83.8 & 83.1 \\
\hline External & 67.7 & 63.6 & 58.9 & 60.1 & 59.8 \\
\hline Domestic & 28.0 & 27.3 & 26.0 & 23.8 & 23.3 \\
\hline \multicolumn{6}{|l|}{ External sector } \\
\hline Current account balance & -15.7 & -25.0 & -31.8 & -28.1 & -25.4 \\
\hline \multirow[t]{2}{*}{ Current account balance including net } & -6.9 & -15.8 & -16.7 & -13.3 & -14.0 \\
\hline & \multicolumn{5}{|c|}{ (In percent of exports of goods and nonfactor services) } \\
\hline External public debt service & 11.2 & 10.6 & 10.3 & 12.9 & 15.3 \\
\hline Amortization & 7.5 & 7.2 & 7.1 & 8.4 & 9.8 \\
\hline Interest & 3.6 & 3.4 & 3.3 & 4.5 & 5.5 \\
\hline \multirow{2}{*}{\multicolumn{6}{|c|}{$\begin{array}{l}\text { Memorandum items: } \\
\text { Nominal GDP at market prices (EC\$ }\end{array}$}} \\
\hline & & & & & \\
\hline Calendar year & 856 & 921 & 984 & 978 & 1,012 \\
\hline \multicolumn{6}{|l|}{ Net imputed international reserves } \\
\hline (U.S. dollars millions; end-of-period) & 63.0 & 60.4 & 55.1 & 64.5 & 64.5 \\
\hline
\end{tabular}

Sources: Dominican authorities; Eastern Caribbean Central Bank (ECCB); and IMF staff estimates and projections

1 / Change relative to the stock of M2 at the beginning of the period.

2/ Including errors and omissions.

3/ Fiscal year (July-June) basis. Figures shown for a given calendar year relate to the fiscal year beginning on July 1 of that year.

4/ Does not include grants that were received but not spent.

5/ Includes central government liabilities to Dominica Social Security. 